\author{
UNIVERSIDADE DE SÃO PAULO \\ FACULDADE DE MEDICINA DE RIBEIRÃO PRETO \\ PROGRAMA DE PÓS-GRADUAÇÃO EM FARMACOLOGIA
}

\begin{abstract}
AVALIAÇÃO DOS EFEITOS DO CANABIDIOL SOBRE AS ALTERAÇÕES NEUROIMUNOENDÓCRINAS E COMPORTAMENTAIS INDUZIDAS PELO ESTRESSE EM CAMUNDONGOS
\end{abstract}

ALICE HARTMANN DOS SANTOS

Ribeirão Preto

2020 
UNIVERSIDADE DE SÃO PAULO

FACULDADE DE MEDICINA DE RIBEIRÃO PRETO

PROGRAMA DE PÓS-GRADUAÇÃO EM FARMACOLOGIA

\section{AVALIAÇÃO DOS EFEITOS DO CANABIDIOL SOBRE AS ALTERAÇÕES NEUROIMUNOENDÓCRINAS E \\ COMPORTAMENTAIS INDUZIDAS PELO ESTRESSE EM CAMUNDONGOS}

ALICE HARTMANN DOS SANTOS

Tese apresentada à Faculdade de Medicina de Ribeirão Preto da Universidade de São Paulo para obtenção do título de Doutora em Ciências.

Área de concentração: Farmacologia.

Orientador: Dr. Francisco Silveira Guimarães.

Co-Orientadora: Dra. Sabrina F. S. Lisboa

Ribeirão Preto

2020 
AUTORIZO A REPRODUÇÃO E DIVULGAÇÃO TOTAL OU PARCIAL DESTE

TRABALHO, POR QUALQUER MEIO CONVENCIONAL OU ELETRÔNICO, PARA FINS DE ESTUDO E PESQUISA, DESDE QUE CITADA A FONTE.

\section{FICHA CATALOGRÁFICA}

Hartmann, Alice.

Avaliação dos efeitos do canabidiol sobre as alterações neuroimunoendócrinas e comportamentais induzidas pelo estresse em camundongos / Alice Hartmann; orientador: Francisco Silveira Guimarães.

$154 \mathrm{p}$.

Tese (Doutorado em Ciências - Área de Concentração: Farmacologia) - Faculdade de Medicina de Ribeirão Preto, Universidade de São Paulo, Ribeirão Preto, SP, 2020.

1. Canabidiol. 2. Estresse. 3. Ansiedade. 4. Depressão. 5. Inflamação. 6. Micróglia. 


\section{FOLHA DE APROVAÇÃO}

Nome: HARTMANN, Alice.

Título: Avaliação dos efeitos do canabidiol sobre as alterações neuroimunoendócrinas e comportamentais induzidas pelo estresse em camundongos.

Tese apresentada à Faculdade de Medicina de Ribeirão Preto da Universidade de São Paulo para obtenção do título de Doutora em Ciências.

Aprovado em:

Banca Examinadora

Prof. Dr.: Sâmia Regiane Lourenço Joca Instituição: Faculdade de Ciências Farmacêuticas de Ribeirão Preto da Universidade de São Paulo (FCFRP - USP).

Julgamento:

Assinatura:

Prof. Dr.: Cristina Aparecida Jark Stern Instituição: Universidade Federal do Paraná (UFPR) Julgamento:

Assinatura:

Prof. Dr.: Newton Sabino Canteras

Instituição: Instituto de Ciências Biomédicas da Universidade de São Paulo (ICB USP).

Julgamento:

Assinatura:

Prof. Dr.: Francisco Silveira Guimarães Instituição: Faculdade de Medicina de Ribeirão Preto - USP (FMRP-USP) Julgamento: Assinatura: 
Ao meu passarinho que me ensinou tanto, que foi exemplo de luta e superação. Aquele que alçou o voo mais longo enquanto eu estava longe. Ao meu amado, vô Romeu. Á ela, sua companheira, que sempre foi nosso exemplo de força, fé, companheirismo e paciência. À minha amada, vó Carolina. 


\section{AGRADECIMENTOS}

À Deus, pelo dom da vida e pela força. Obrigada por me trazer respostas e por me mostrar que, apesar de toda a dor, dificuldades e sofrimento, a vida sempre é boa com quem é bom com a vida. Obrigada por todas as oportunidades e recomeços.

Aos meus pais, Ivone e Abgair, por me criarem para o mundo, apesar de todo o apego, amor e saudade. Obrigada por entenderem que a minha ausência, apesar de sofrida, é necessária. Obrigada pelo incentivo incondicional. Obrigada pelas oportunidades, sacrifícios, educação e esforços durante a minha existência.

Às minhas mais que irmãs, Christina e Ana Raquel, por serem as minhas parceiras de vida. Obrigada por me fazerem acreditar que independentemente do que seja e de onde esteja, sempre estarão comigo. Obrigada por tanto amor e por serem a minha maior torcida.

Aos meus sobrinhos - Carolina, Vitor, Fernando, Francisco e Aurora - por me fazerem acreditar e serem esperança. Obrigada pelos ingênuos ensinamentos e pelo amor.

Ao meu noivo, Johannes Bruno, pelo apoio irrestrito. Obrigada por entender a minha prioridade, mesmo quando ela significava ausência. Gratidão pelas idas e voltas ao Instituto, principalmente nos horários loucos e finais de semana; além do auxílio nesses últimos tempos com a escrita da tese. Obrigada por sempre me mostrar que ia ficar tudo bem, acreditar em mim, se preocupar com o meu bem estar e procurar me entreter. Obrigada por sempre oferecer e tentar ajudar. Você me inspira e motiva a ser cada dia melhor.

Ao meu orientador, Francisco Silveira Guimarães, por basicamente tudo. O Sr. possui a minha profunda admiração e respeito, de modo que faltam palavras para te agradecer. Obrigada pela confiança, pela liberdade, pelas oportunidades, pela tranquilidade, pelos momentos de descontração e por sempre ver o lado minimamente positivo das coisas. Obrigada pela constante preocupação com nosso bem estar, em fazer com que nos sintamos em casa e por ser um excepcional exemplo de profissional.

À minha coorientadora, veterana e amiga, Sabrina, a minha eterna gratidão e profundo respeito. Obrigada pelas palavras confortantes, pelo realismo, por confiar em mim e por nunca me deixar esmorecer. Obrigada pelas risadas, por ser sempre presente, por todo auxílio e por compartilhar o seu conhecimento comigo. Obrigada pela amizade. Você é o meu grande exemplo de perseverança, resiliência, determinação e mulher na ciência.

Ao meu supervisor no exterior, Dr. Carsten Wotjak, por me permitir e ensinar tanto. Obrigada pelas inúmeras oportunidades, reuniões científicas, incentivos, palpites, opiniões, conselhos, 
momentos de descontração e por sempre estar preocupado com o meu bem estar. Sou muito grata e realizada pela oportunidade de trabalhar contigo, tens meu imenso respeito e admiração.

Aos Prof. Felipe e Leonardo, bem como seus respectivos alunos, pela amizade, carinho, apoio, ensinamentos e dedicação. Obrigada pela prestatividade e atenção dispensados a mim sempre que precisei.

À Prof. Sâmia pelo carinho, palavras amigas, motivação, sugestões e por compartilhar seu conhecimento comigo.

À Prof. Alline pelas sugestões e discussões científicas. Aos seus alunos pela amizade, auxílio, apoio e prestatividade.

Ao Dr. Alon Chen, Dr. Jan Deussing e Dr. Mathias Schmidt pela acessibilidade, reuniões, sugestões, discussões de resultados e oportunidades. Obrigada, Jan, pelo auxílio quando Carsten esteve ausente.

Às melhores companheiras de laboratório que eu poderia ter - Andreza, Carla, Isadora, Naielly e Nicole - por todo companheirismo, ensinamentos e amizade. Obrigada pelas discussões científicas, pelo auxílio enquanto estive distante, pelas risadas e momentos de descontração. Obrigada por fazerem o convívio diário ser prazeroso e por ampararmos umas às outras quando necessário.

Aos meus colegas de laboratório na Alemanha - Daniel, Julia, Marie, Mojan, Vivian, Fabiola, Tibor, Silvio, Prabahan, Turan, Nidhi, Oriana, Paulina, Suellen - e aos colegas do Instituto Max Planck de Psiquiatria. Obrigada pelas oportunidades de colaboração, auxílio, ensinamentos, por não medirem esforços para me ajudar e pelos momentos de descontração.

Aos meus amigos e companheiros dessa intensa e desgastante jornada de pós-graduação. Aos amigos e companheiros que Ribeirão Preto trouxe. Obrigada por permitirem o convívio agradável, pelo auxílio, apoio e força quando necessário e, principalmente, por terem feito meus dias mais alegres. Agradeço, especialmente à Nicole, Pedro, Mayara, Flávio, Jéssica, Aline, Carla, Sabrina e Vinícius por estarem comigo sempre, nos meus melhores e piores momentos.

Aos amigos e companheiros da maior aventura que eu já vivi, por fazerem a minha vida mais fácil e mais feliz no velho continente. Em especial, Tibor, Silvio, Fabiola, Oriana, Tanusree, Suellen, Julien, Lotte, Isabella, Francesco, Rosalba, Anna, Fred, Kamilla e Juci. Fabiola, gratidão por todos os ensinamentos, discussões e auxílio nos experimentos in vitro. 
Aos demais Professores e colegas pós-graduandos do Depto. de Farmacologia pela cordialidade e disposição em me auxiliar quando necessário, bem como pelas conversas descontraídas nos corredores.

Ao apoio técnico de Laura, Eleni, Inês e Marcos. Laura, muito obrigada pela eficiência e disposição em sempre me auxiliar, pelas risadas e apoio.

Ao apoio técnico de Eliana, Orlando e Marcos no cuidado com os animais do biotério.

Ao apoio técnico, cuidadores de animais e funcionários do Instituto Max Planck de Psiquiatria. Agradeço, em especial, a Nicole pelo incansável e inestimável auxílio antes, durante e após o meu tempo de Doutorado Sanduíche.

Aos secretários do Depto. de Farmacologia - Ramón e Gislaine - pela competência, profissionalismo, disponibilidade, carinho e atenção com que me auxiliaram.

Aos membros da banca pela disponibilidade, atenção, auxílio e colaboração na finalização deste trabalho.

A todos os professores que tive, ao longo da vida, por cada ensinamento e dedicação.

Aos meus amigos de Cascavel e Londrina.

Ao Conselho Nacional de Desenvolvimento Científico e Tecnológico (CNPq) e Coordenação de Aperfeiçoamento de Pessoal de Nível Superior (CAPES) pelo apoio e suporte à pesquisa nacional.

A Fundação de Amparo à Pesquisa do Estado de São Paulo (FAPESP) pelo apoio financeiro no

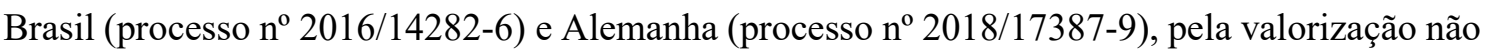
defasada de profissionais e pela maior experiência profissional e pessoal já experenciada até esse momento, o Doutorado Sanduíche.

A todos aqueles que contribuíram direta ou indiretamente para a realização deste trabalho. 
"Se quiser triunfar na vida,

faça da perseverança a sua melhor amiga; da experiência, o seu conselheiro; da prudência, o seu irmão mais velho; e da esperança, o seu anjo da guarda." 
As opiniões, hipóteses, conclusões ou recomendações expressas neste material são de responsabilidade do(s) autor(es) e não necessariamente refletem a visão da FAPESP. 
$\underline{\text { Resumo }}$ 


\section{RESUMO}

HARTMANN, A. Avaliação dos efeitos do canabidiol sobre as alterações neuroimunoendócrinas e comportamentais induzidas pelo estresse em camundongos. 2020. 154 p. Tese (Doutorado). Faculdade de Medicina de Ribeirão Preto - Universidade de São Paulo, 2020.

Diversas evidências sugerem o envolvimento de citocinas pró-inflamatórias em pacientes psiquiátricos e modelos animais de transtornos mentais. Interleucina-1 $\beta$ (IL-1 $\beta$ ), amplamente descrita como agente neuroinflamatório, apresenta-se elevada em pacientes depressivos, ansiosos e com transtorno de estresse pós-traumático (PTSD). A via de NFkB e o inflamassoma de NLRP3 medeiam a transcrição e função de IL-1 $\beta$, induzindo a ativação do sistema imune inato e inflamação. A ativação deste complexo tem sido amplamente relacionada à transtornos mentais. O canabidiol (CBD) possui inúmeros efeitos terapêuticos já descritos. Entretanto, a interação entre CBD e sistema imunológico, além do envolvimento de mecanismos imunológicos sobre os efeitos comportamentais da droga, ainda são pouco conhecidos. Desse modo, este trabalho objetivou avaliar o envolvimento do inflamassoma de NLRP3 no mecanismo pelo qual o CBD previne ou reverte alterações comportamentais e neuroimunoendócrinas em modelos animais. Para isso, machos C57BL/6 adultos foram expostos aos protocolos: estresse crônico imprevisível (21 dias), estresse por restrição (6h) ou 2 choques inescapáveis nas patas (1,5mA). Adicionalmente, usou-se modelo animal de ansiedade baseado no acasalamento seletivo. Os resultados obtidos através do modelo de estresse crônico imprevisível evidenciaram que os animais estressados apresentam redução do peso corpóreo, aumento do tempo de imobilidade no teste do nado forçado e hipolocomoção no teste do campo aberto em comparação com animais controle. Entretanto, no teste de supressão da alimentação pela novidade, os animais não apresentavam a supressão da alimentação apenas pela neofobia, mas sim de modo geral. O teste de preferência pela sacarose não nos forneceu dados robustos. O CBD não alterou os efeitos comportamentais do estresse. Diante da baixa reprodutibilidade dos resultados obtidos com este modelo, decidimos utilizar o modelo de estresse por restrição por 6 horas. Esse modelo diminuiu o tempo de permanência e o número de entradas nos braços abertos do labirinto em cruz elevado (LCE) 24 h e 7 dias após o estresse. Não houveram alterações no teste de suspensão pela cauda e peso corpóreo. O tratamento repetido com o CBD $30 \mathrm{mg} / \mathrm{kg}$ preveniu o estabelecimento das consequências comportamentais do estresse nos animais estressados, 
porém induziu efeito tipo-ansiogênico per se nos animais não estressados. Durante o doutorado sanduíche, foram utilizados camundongos com comportamentos extremos relacionados a ansiedade de modo inato (HAB) e seus respectivos controles (NAB). Os animais HAB apresentaram comportamentos relacionados à ansiedade no teste do LCE e beetle mania task quando comparados aos NAB. No teste de medo condicionado ao som, os animais HAB são capazes de extinguir a memória aversiva, porém não são capazes de consolidar a extinção e possuem recuperação espontânea das respostas de medo, quando comparados aos animais NAB. O tratamento com o CBD (15 e $30 \mathrm{mg} / \mathrm{kg}$ ) não induziu alterações em comparação com o grupo veículo nos animais HAB em nenhum dos testes utilizados. Diante da ausência de efeitos agudos do CBD, decidimos trocar para um modelo animal de PTSD. Três semanas após o trauma, o tratamento diário teve início: veículo ou CBD (10 a 30 mg/kg, 1 injeção i.p.). Depois de uma semana de tratamento, os animais foram testados para generalização e efeitos de longa duração dos choques e, 24 horas depois, os animais foram testados para expressão e recuperação do medo. O estresse aumentou o tempo de congelamento e diminuir o número de rearings em ambos os testes. O tratamento repetido com o CBD não reverteu as alterações induzidas pelo modelo. Não houve efeito do estresse e/ou do tratamento nos animais submetidos ao trauma e testados no beetle mania task. Em geral, as inúmeras limitações enfrentadas dificultaram o andamento do projeto. Os resultados obtidos com o modelo de estresse único por restrição evidenciam que esse protocolo induz alterações que viabilizam estudos pré-clínicos de transtorno mentais e que o tratamento repetido com o CBD, na dose de $30 \mathrm{mg} / \mathrm{kg}$, induz um efeito dual que depende da condição prévia de estresse do animal. Já os estudos com a linhagem $\mathrm{HAB}$ evidenciam que esses animais possuem o fenótipo relacionado à ansiedade de modo inato, porém que o CBD não possui efeito agudo nesses animais. Por fim, o modelo animal de PTSD, induziu alterações comportamentais robustas e duradouras. Apesar de o CBD não alterar os efeitos do estresse, este resultado pode sugerir que este fitocanabinoide não seja efetivo em pacientes com o quadro de TEPT já estabelecido após um longo período do trauma; uma vez que estudos prévios de nosso grupo e de outros grupos evidenciaram que o composto pode prevenir as consequências comportamentais em outros modelos animais de TEPT, quando administrado logo após o trauma ou após um novo estresse - reminder.

Palavras-chave: Canabidiol. Estresse. Ansiedade. Depressão. Inflamação. Micróglia. 
$\underline{\text { Abstract }}$ 


\begin{abstract}
HARTMANN, A. Evaluation of the Cannabidiol effects under neuroimmunoendocrine and behavioral alterations induced by stress in mice. 2020. 154 p. PhD Thesis. Ribeirão Preto Medical School - University of São Paulo, 2020.

Several pieces of evidence suggest the involvement of proinflammatory cytokines in psychiatric patients as well as in animal models of mental disorders. Interleukin-1 $\beta$ (IL$1 \beta$ ) levels, widely described as neuroinflammatory agent, is increased in patients with depression, anxiety and post-traumatic stress disorder (PTSD). NFkB and NLRP3 inflammasome pathway mediate IL- $1 \beta$ transcription and function. The activation of this complex has been related to mental disorders. Cannabidiol (CBD) has several therapeutical effects already described. However, the interaction between CBD and immune system, as well as the involvement of immunological mechanisms mediating behavioral effects of this drug, are still poorly understood. This work aimed to evaluate the involvement of NLRP3 inflammasome pathway on the mechanisms by which CBD can prevent of reverse behavioral and neuroimmunoendocrine alterations in animal models. Adult male C57B1/6 mice were exposed to the following protocols: chronic unpredictable stress (CUS; 21 days), restraint stress (RS; 6h) or 2 inescapable foot shocks (PTSD; 1.5mA). Additionally, an animal model of anxiety, based on selective breeding, was used. Results obtained with CUS model showed a reduction on the body weight, increase in immobility time on the forced swim test as well as hipolocomotion on the open field test of stressed mice in comparison with control. However, on the novelty suppressed feeding test, animals showed that the feeding was generally suppressed and not just by neophobia. Sucrose preference test wasn't able to give us reliable results. CBD wasn't able to alter behavioral effects induced by stress. Considering the low reproducibility of the results obtained with this model, we decided to use RS. Six hours of RS decreased the time spent and number of entries in the open arms of the elevated plus maze (EPM) $24 \mathrm{~h}$ and 7 days after stress. There were no changes on the tail suspension test and body weight. Repeated treatment with CBD (30 mg/kg) prevents behavioral consequences of stress in stressed mice, despite induced an anxiogenic-like effect per se in controls. During the abroad internship in Germany, we used mice with high-anxiety trait (HAB) and their respective controls (NAB). HAB mice showed an increase in anxiety related behaviors in the EPM and beetle mania task when compared
\end{abstract}


to NAB. In the auditory fear conditioning test, HAB mice did extinguish aversive memory, however were not able to consolidate extinction memory and spontaneously recovered fear responses when compared to NAB. CBD treatment (15 and $30 \mathrm{mg} / \mathrm{kg}$ ) did not show any improvement in comparison with vehicle in HAB mice. In the absence of acute CBD effects, we decided to use an animal model of PTSD. Three weeks after the trauma, daily treatment with vehicle or CBD (10-30 mg/kg, 1 injection i.p.) started. After one week of treatment, animals were tested for generalization and long-lasting consequences of shocks. Twenty for hours later, mice were tested for fear expression and recovery. Stress increased freezing time and decreased number of rearings in both tests. Repeated treatment with CBD did not revert the alterations induced by this model. In the same way, there was no effect of stress and/or treatment of mice submitted to trauma and tested in the beetle mania task. In general, the difficulties faced hindered the progress of the project. Results obtained with CUS suggest that this protocol induce changes that makes possible preclinical studies of mental disorders and that repeated treatment with $\mathrm{CBD}, 30 \mathrm{mg} / \mathrm{kg}$, induce a dual effect that depends on the previous stress condition of the animal. The experiment with HAB lineage evidence that these mice did present innate anxiety-related phenotype, despite CBD had no acute effect. Finally, PTSD model is able to induce robust and long-lasting behavioral alterations in mice. Although CBD wasn't able to ameliorate these stress' effects, this result can suggest that this phytocannabinoid is not effective in patients with PTSD already installed after a long period of trauma; since previous studies by our and other groups have shown that the compound can prevent behavioral consequences in other animal models of PTSD, when administered shorly after the trauma or a new stressor - reminder.

Key-words: Cannabidiol. Stress. Anxiety. Depression. Inflammation. Microglia. 
Lista de Abreviaturas 


\section{LISTA DE ABREVIATURAS}

2-AG - 2-araquidonoilglicerol

AEA - Anandamida

ANCOVA - Análise de covariância

ANOVA - Análise de variância

ASC - do inglês, apoptosis-associated speck-like protein containing a CARD domain

ATP - Adenosina trifosfato

BMT - Teste de mania induzida pelo besouro (do inglês, Beetle mania task)

CB1 - Receptor Canabinoide do tipo 1

CB2 - Receptor Canabinoide do tipo 2

CBD - Canabidiol

CPF - Córtex pré-frontal

CPFvm - Córtex pré-frontal ventro medial

CRH - Hormônio liberador de corticotrofina

CUS - Estresse crônico imprevisível (do inglês, chronic unpredictable stress)

DAMP - Padrões Moleculares Associados a Danos (do inglês, Damage-associated molecular patterns)

DMSO - Dimetilsufóxido

DMSV - Manual diagnóstico e estatístico de transtornos mentais - $5^{\mathrm{a}}$ edição (do inglês, Diagnostic and statistical manual of mental disorders $-5^{\text {th }}$ ed)

EPM - Erro padrão da média

GC - Glicocorticoides

GR - Receptores de Glicocorticoides (do inglês, glucocorticoid receptors)

GRE - Elementos de resposta aos glicocorticoides (do inglês, Glucocorticoid responsive elements) 
HHA - Eixo hipotálamo hipófise-adrenal

HIP - Hipocampo

I.P. - Injeção intraperitoneal

Iba-1 - molécula adaptadora de ligação ao cálcio ionizado-1 (do inglês, Ionized calcium binding adaptor molecule 1)

IL-10 - Interleucina 10

IL-1及 - Interleucina 1-beta

IL-6 - Interleucina 6

iNOS - Óxido nítrico sintase induzível (do inglês, Inducible nitric oxide synthase)

LCE - Labirinto em cruz elevado

NFkB - Fator nuclear kappa B

nGRE - Elementos negativos de resposta aos glicocorticoides (do inglês, negative glucocorticoid responsive elements)

NLRP3 - do inglês, Nod-like receptor protein 3

NLRs - Receptores do tipo NOD (do inglês, Nucleotide-binding oligomerization domain-like receptors)

NOD - Domínio de ligação à nucleotídeos e oligomerização (do inglês, Nucleotide-binding oligomerization domain)

OFT - Teste de campo aberto (do inglês, open field test)

P2X7 - Receptor purinérgico do subtipo 7 (do inglês, Purinergic receptor subtype 7)

PAMP - Padrões Moleculares Associados a Patógenos (do inglês, Pathogen-associated molecular patterns)

PPAR- $\boldsymbol{\gamma}$ - Receptor ativado por proliferadores de peroxissoma gama (do inglês, Peroxisome proliferator-activated receptor gamma).

PTSD - Transtorno de estresse pós-traumático (do inglês, post traumatic stress disorder) ANOVAr - ANOVA para medidas repetidas 
RNA - Ácido ribonucleico

RNAm - RNA mensageiro

ROS - Espécies reativas de oxigênio (do inglês, Reactive oxygen species)

RRP - Receptores de reconhecimento padrão

SERT - Transportador de serotonina (do inglês, Serotonin transporter)

SNA - Sistema nervosa autônomo

SNAs - Sistema nervosa autônomo simpático

SNC - Sistema Nervoso Central

SNK - Student-Newman-Keuls

THC - $\Delta^{9}$-tetraidrocanabinol

TLRs - Receptores do tipo Toll (do inglês, Toll-like receptors)

TNF- $\boldsymbol{\alpha}-$ Fator de necrose tumoral alfa

TRPV1 - Receptor potencial transitório vanilóide do tipo 1 (do inglês, transient receptor potential vanilloid type 1) 
Lista de Figuras 


\section{LISTA DE FIGURAS}

Fig. 1 - Cronograma de agentes estressores utilizados no protocolo de estresse crônico imprevisível.

Fig. 2 - Protocolo experimental utilizado no experimento 1.

Fig. 3 - Protocolo experimental utilizado no experimento 2.

Fig. 4 - Protocolo experimental utilizado no experimento 4.

Fig. 5 - Protocolo experimental utilizado no experimento 7.

Fig. 6 - Protocolo experimental utilizado no experimento 8.

Fig. 7 - Protocolo experimental utilizado no experimento 9.

Fig. 8 - Delineamento experimental para o protocolo de medo condicionado ao som ao qual animais $\mathrm{HAB}$ e NAB foram submetidos.

Fig. 9 - Procedimento experimental para avaliação dos efeitos do tratamento repetido com o Canabidiol (10 e $30 \mathrm{mg} / \mathrm{kg}$ ) ou VEI sobre alterações comportamentais induzidas por um modelo animal de PTSD.

Fig. 10 - Efeitos do estresse crônico imprevisível sobre o peso corporal e sobre parâmetros comportamentais em camundongos (Experimento 1).

Fig. 11 - Efeitos do estresse crônico imprevisível sobre o peso corporal e parâmetros comportamentais em camundongos (Experimento 2).

Fig. 12 - Efeitos do estresse crônico imprevisível sobre o peso corporal e parâmetros comportamentais em camundongos (Experimento 3).

Fig. 13 - Efeitos do estresse crônico imprevisível sobre o peso corporal e parâmetros comportamentais em camundongos (Experimento 4). 
Fig. 14 - Efeitos do estresse crônico imprevisível sobre o peso corporal e parâmetros comportamentais em camundongos (Experimento 5).

Fig. 15 - Efeitos do estresse crônico imprevisível sobre a expressão relativa de genes envolvidos com a plataforma do inflamassoma de NLRP3.

Fig. 16 - Efeitos do estresse crônico imprevisível sobre os níveis de IL-1 $\beta$ no soro e regiões cerebrais de camundongos.

Fig. 17 - Efeitos do estresse crônico imprevisível e do tratamento com o canabidiol sobre o peso corporal e parâmetros comportamentais em camundongos (Experimento 7).

Fig. 18 - Efeitos do estresse crônico imprevisível e tratamento com canabidiol sobre o peso corporal e sobre parâmetros comportamentais em camundongos (Experimento 8).

Fig. 19 - Efeitos do estresse crônico imprevisível e tratamento repetido com canabidiol ou fluoxetina sobre o peso corporal e parâmetros comportamentais em camundongos.

Fig. 20 - Efeitos do estresse único por restrição sobre a porcentagem de tempo e entradas nos braços abertos em camundongos submetidos ao teste do labirinto em cruz elevado.

Fig. 21 - Efeitos do estresse único por restrição e do tratamento com o canabidiol em camundongos submetidos ao teste do labirinto em cruz elevado, suspensão pela cauda e peso corporal.

Fig. 22 - Efeitos do tratamento agudo com o canabidiol em camundongos HAB e NAB avaliados no teste do labirinto em cruz elevado (LCE).

Fig. 23 - Efeitos do tratamento agudo com o canabidiol em camundongos HAB e NAB avaliados no teste de mania induzida pelo besouro (BMT).

Fig. 24. LPS aumenta a expressão relativa dos genes de IL-1 $\beta$, TNF- $\alpha$ e IL-6 em cultura primária de micróglias. 
Fig. 25. Exposição repetida ao canabidiol não melhora o prejuízo comportamental induzido pelo modelo de PTSD baseado em choques nas patas.

Fig. 26. Modelo de PTSD falha em induzir alterações comportamentais no teste de mania induzida pelo besouro.

Fig. 27. Modelo de PTSD baseado em choques nas patas aumenta o tempo de congelamento dos animais, mas não altera parâmetros relacionados à ansiedade no teste do labirinto em cruz elevado. 
$\underline{\text { Sumário }}$ 


\section{Sumário}

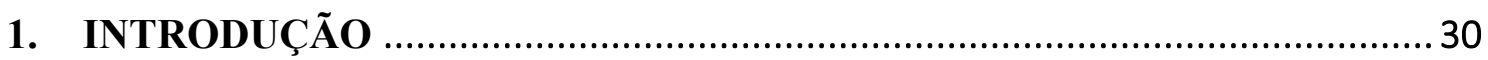

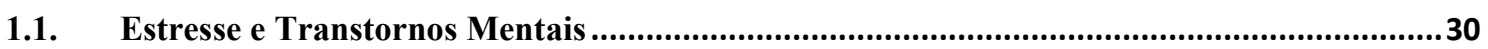

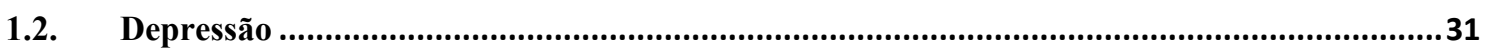

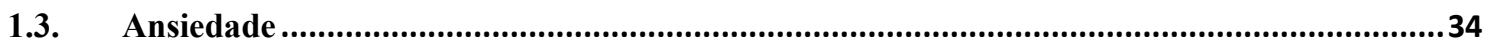

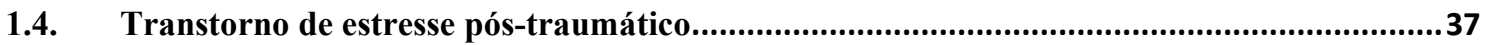

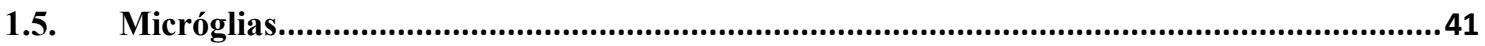

1.6. Receptores de reconhecimento padrão, inflamassoma de NLRP3 e transtornos mentais ....45

1.7. Eixo Hipotálamo-Hipófise-Adrenal e Glicocorticoides ..................................................48

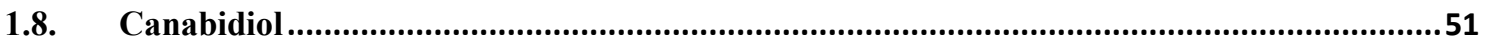

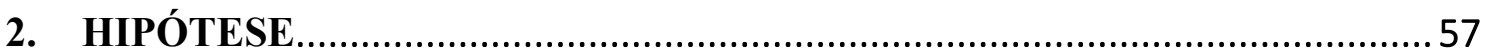

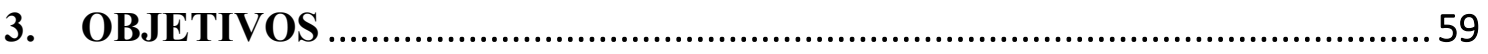

ORIGINAIS - PRIMEIRA PARTE DO PROJETO (BRASIL) ...........................59

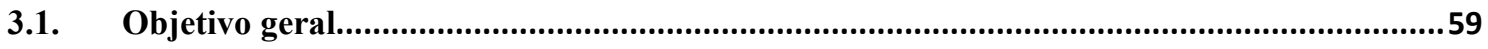

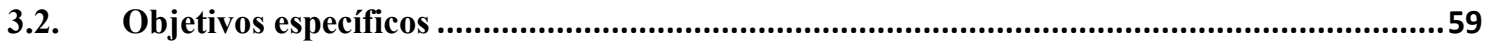

SECUNDÁRIOS - SEGUNDA PARTE DO PROJETO (ALEMANHA) ............ 60

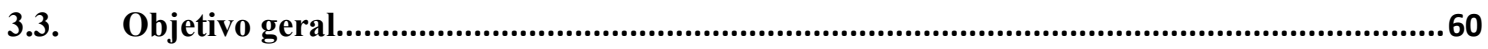

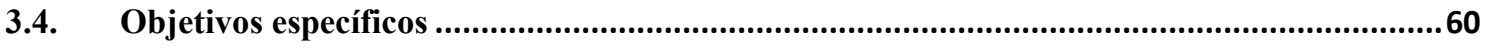

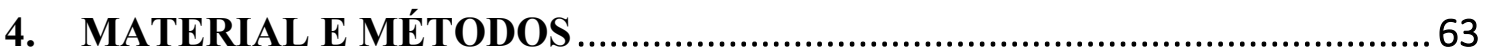

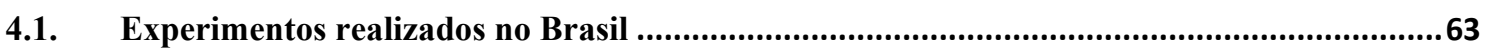

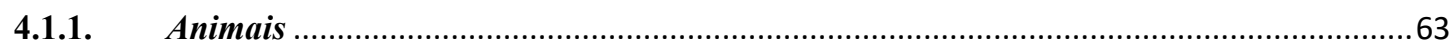

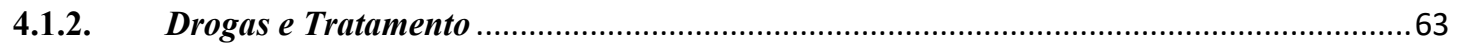

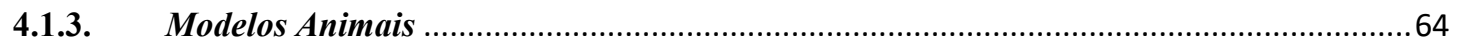

4.1.3.1. Estresse Crônico Imprevisível (CUS, "Chronic Unpredictable Stress") .........................64

4.1.3.2. Estresse único por restrição.................................................................................65

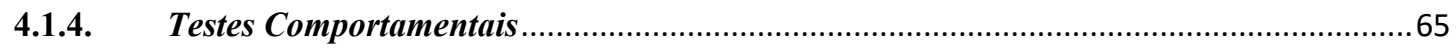

4.1.4.1. Teste de preferência pela sacarose (SPT, "Sucrose preference test").............................65 
4.1.4.2. Teste do labirinto em cruz elevado (LCE) ..............................................................66

4.1.4.3. Teste do nado forçado (FST, "Forced swim test") ......................................................66

4.1.4.4. Teste de supressão da alimentação pela novidade (NSF, "Novelty supressed fedding").67

4.1.4.5. Teste de campo aberto (OFT, "Open field test") ......................................................67

4.1.4.6. Teste de suspensão pela cauda (TST, "Tail suspension test")........................................68

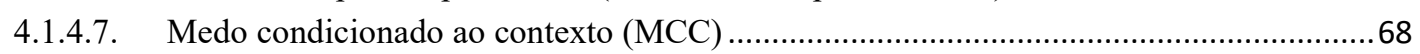

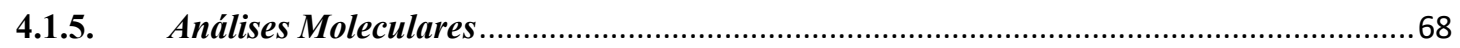

4.1.5.1. Eutanásia e coleta de órgãos para análises moleculares................................................68

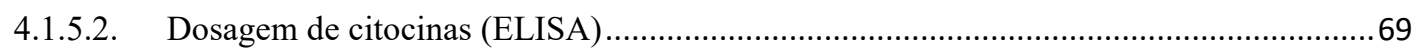

4.1.5.3. Análise de expressão gênica por PCR em tempo real (qRT-PCR) ................................69

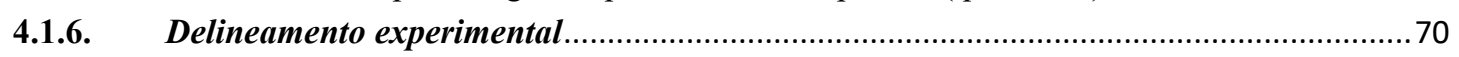

4.1.6.1. Padronização do modelo de estresse crônico imprevisível por 21 dias ............................70

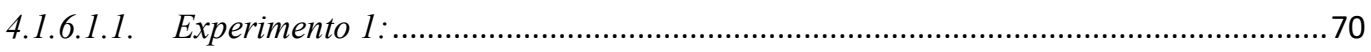

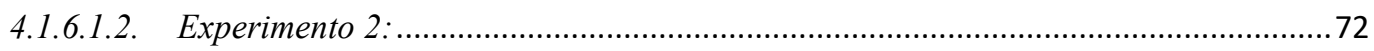

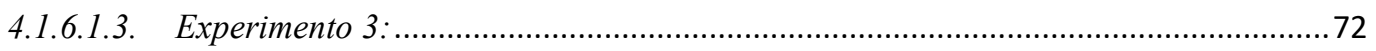

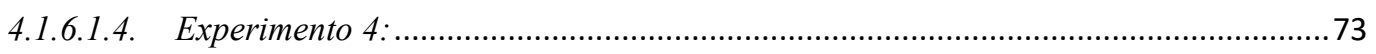

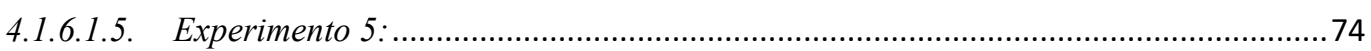

4.1.6.2. Expressão relativa de genes relacionados à plataforma do inflamassoma de NLRP3 e dosagens séricas e estrutura-específicas de IL-1 $\beta$ para padronização das alterações moleculares

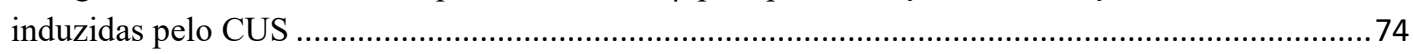

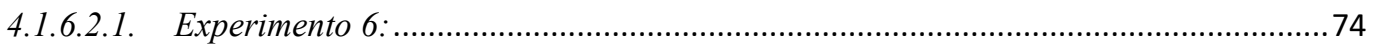

4.1.6.3. Avaliação dos efeitos do Canabidiol sobre as alterações comportamentais induzidas pelo estresse crônico imprevisível ............................................................................................ 74

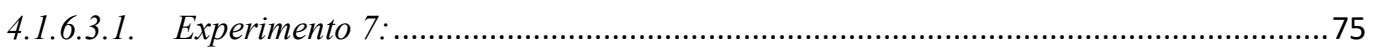

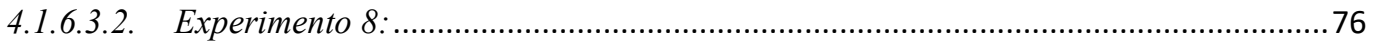

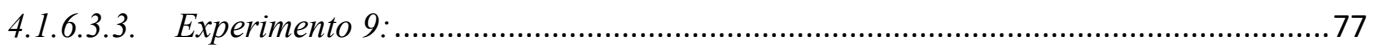

4.1.6.4. Padronização do modelo de estresse único por restrição.................................................78

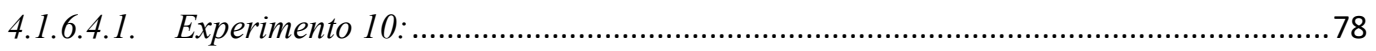

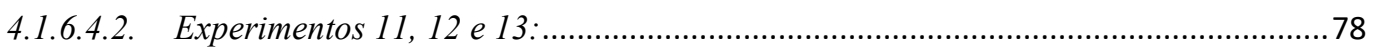

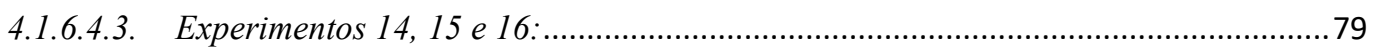

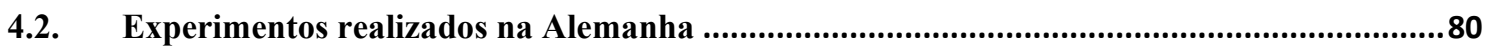

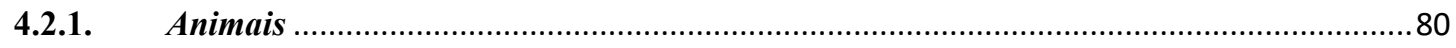

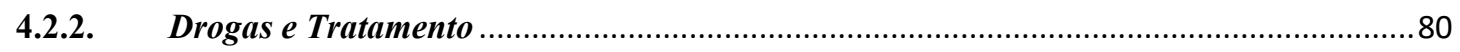

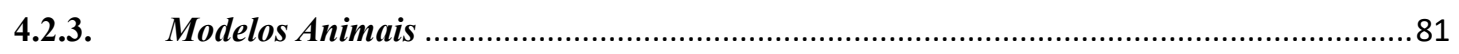

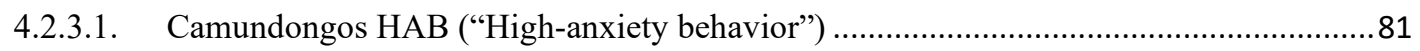

4.2.3.2. Modelo animal de PTSD baseado em choques inescapáveis ...........................................81

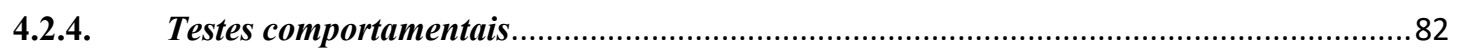

4.2.4.1. Teste do labirinto em cruz elevado (LCE) ....................................................................8 82

4.2.4.2. Teste de mania induzida pelo besouro (BMT, "Beetle mania task")..............................82

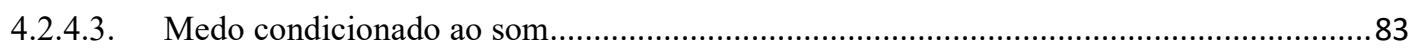

4.2.4.4. Expressão de medo e generalização ..............................................................................8 84

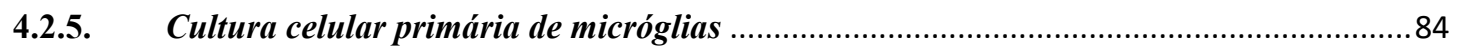

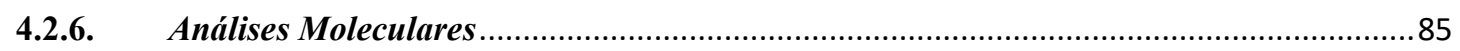

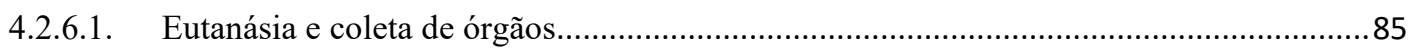

4.2.6.2. Análise de expressão gênica por PCR em tempo real (qRT-PCR) .................................85

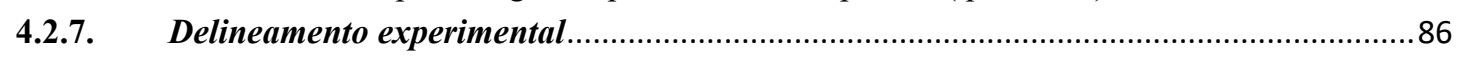


4.2.7.1. Avaliação dos efeitos do Canabidiol sobre parâmetros comportamentais e imunológicos em um modelo psicopatológico genético de ansiedade .................................................................8 86

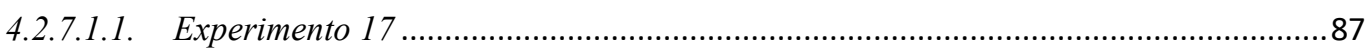

4.2.7.2. Avaliação dos efeitos do Canabidiol sobre culturas primárias de micróglias estimuladas com LPS 89

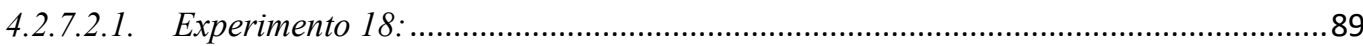

4.2.7.3. Efeitos do Canabidiol em camundongos submetidos ao protocolo de PTSD..................89

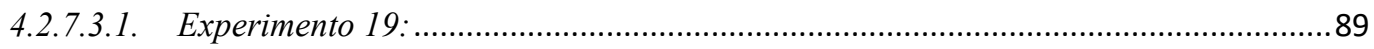

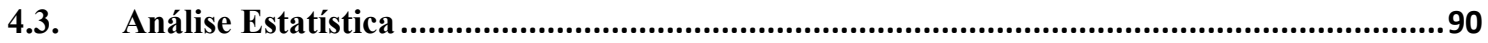

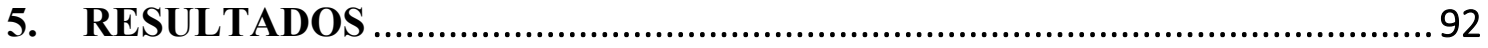

EXPERIMENTOS REALIZADOS NO BRASIL ................................................. 92

5.1. Padronização do modelo de estresse crônico imprevisível por 21 dias ...............................92

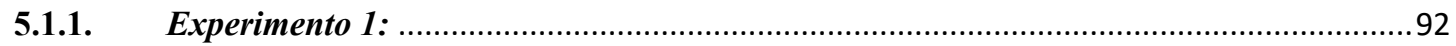

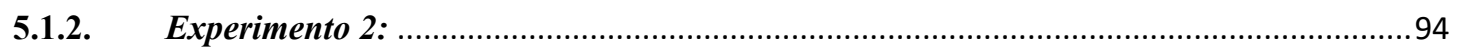

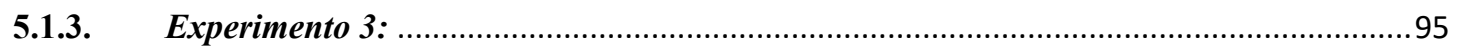

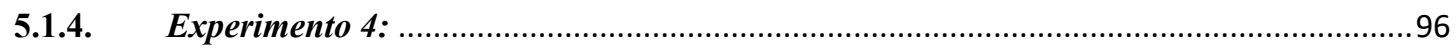

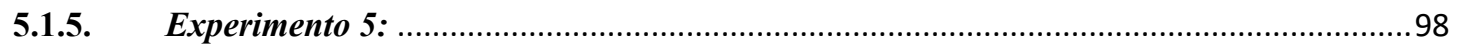

5.2. Expressão relativa de genes relacionados à plataforma do inflamassoma de NLRP3 e dosagens séricas e estrutura-específicas de IL-1ß para padronização das alterações moleculares induzidas pelo CUS.

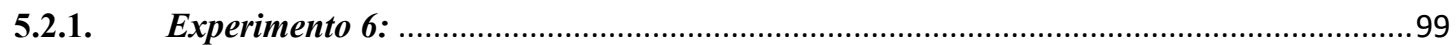

5.3. Avaliação dos efeitos do Canabidiol sobre as alterações comportamentais induzidas pelo

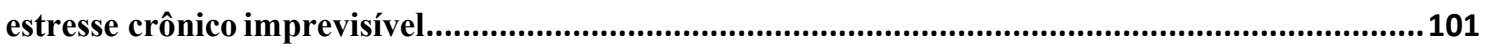

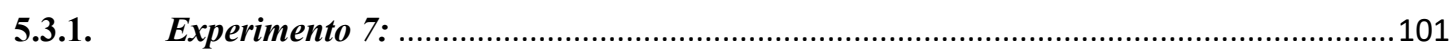

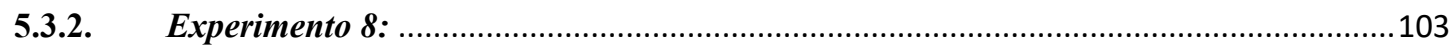

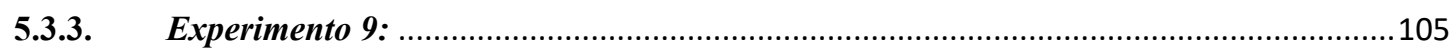

5.4. Padronização do modelo de estresse único por restrição .................................................. 106

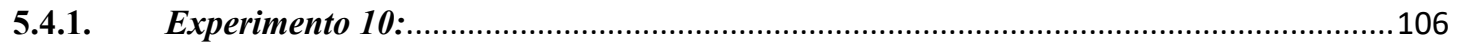

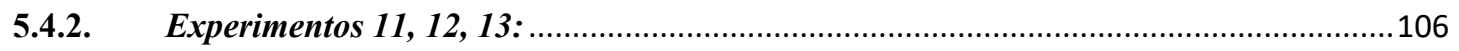

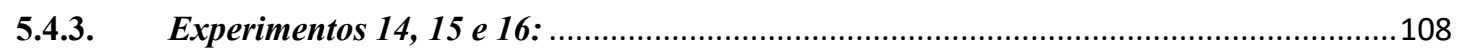

EXPERIMENTOS REALIZADOS NA ALEMANHA ............................. 108

5.5. Avaliação dos efeitos Canabidiol sobre parâmetros comportamentais e imunológicos em um modelo psicopatológico genético de ansiedade ..................................................................108

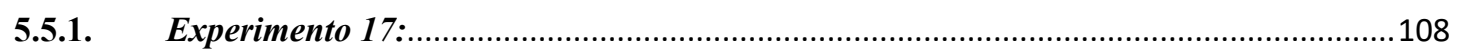

5.6. Avaliação dos efeitos do Canabidiol sobre culturas primárias de micróglias estimuladas com LPS

5.6.1. Experimento 18: 
5.7. Efeitos do Canabidiol em camundongos submetidos a um protocolo de PTSD.................112

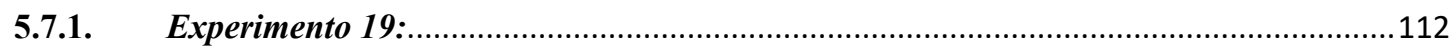

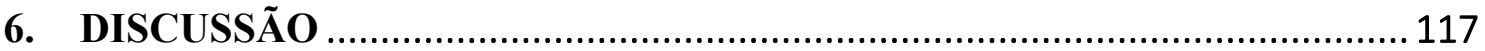

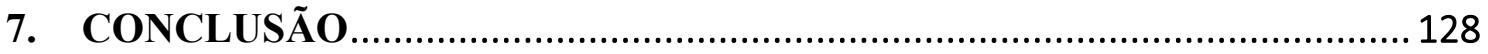

8. REFERÊNCIAS BIBLIOGRÁFICAS ............................................ 131 
Introdução 


\section{INTRODUÇÃO}

\subsection{Estresse e Transtornos Mentais}

O estresse pode ser definido como a resposta fisiológica a um estímulo que ameace a homeostasia do organismo. Nesse sentido, quando essa ameaça é percebida, alterações em diferentes sistemas são deflagradas, como ativação do sistema nervoso autônomo simpático (SNAs) e do eixo hipotálamo-hipófise-adrenal (HHA), mediados pela neurotransmissão noradrenérgica e liberação de glicocorticoides (GC), respectivamente. As respostas fisiológicas rápidas são caracterizadas pelo aumento da pressão arterial, frequência cardíaca, ventilação pulmonar e estado de hipervigilância. Além disso, existem as alterações comportamentais e cognitivas oriundas da exposição ao estresse, também mediadas pelo cortisol e noradrenalina, através de receptores noradrenérgicos e glicocorticoides (GR), em estruturas que desempenham papéis importantes no processamento e consolidação de memórias emocionais - como amígdala, hipocampo e córtex pré-frontal. Esse conjunto de respostas tem alto valor para sobrevivência, uma vez que não depende unicamente da resposta imediata ao agente estressor, mas também da habilidade de integrar e memorizar informações a respeito da situação vivenciada para que, em casos futuros, haja uma resposta efetiva adequada (DE KLOET; JOELS; HOLSBOER, 2005; DE KLOET; OITZL; JOELS, 1999; FINSTERWALD; ALBERINI, 2014; LUPIEN; MAHEU; TU; FIOCCO et al., 2007; RAY; GULATI; RAI, 2017; RUSSELL; LIGHTMAN, 2019).

Quando esses processos ocorrem de modo apropriado, ou seja, quando há alostasia, há também a adaptação a situação estressante (CANNON, 1932; MCEWEN, 1998; SELYE, 1998). Entretanto, falhas ou a incapacidade na adaptação são amplamente relacionados ao desenvolvimento de doenças (MCEWEN, 1998; 2000; MCEWEN; GIANAROS, 2010).

Inúmeras variáveis alteram as respostas emocionais ao estresse, como a intensidade do agente estressor, duração, cronicidade, previsibilidade e controlabilidade (FINSTERWALD; ALBERINI, 2014; LUPIEN; MAHEU; TU; FIOCCO et al., 2007). Nesse sentido, níveis 
adequados de estresse estimulam a cognição e os processos relacionados à formação de memórias, como aquisição e consolidação. Entretanto, a exposição a estressores intensos e/ou por longos períodos induz prejuízos cognitivos associados ao desenvolvimento de transtornos mentais (DE KLOET; JOELS; HOLSBOER, 2005; MCEWEN, 2000; MCEWEN; GIANAROS, 2010).

Nas últimas décadas, inúmeros estudos têm evidenciado que animais experimentais submetidos a diferentes protocolos agudos e repetidos de estresse exibem alterações comportamentais relacionadas à ansiedade, depressão, transtorno de estresse pós-traumático, dentre outros (CAMPOS; FOGACA; AGUIAR; GUIMARAES, 2013).

\subsection{Depressão}

A depressão é um transtorno mental que compreende múltiplas manifestações e sintomas, destacando-se o desânimo persistente, ideias suicidas, distúrbios do sono, diminuição de apetite, dificuldade de concentração, déficits cognitivos, e anedonia (Associação Americana de Psiquiatria-APA, 2013). A anedonia, um dos principais sintomas desse transtorno, é a dificuldade ou incapacidade de sentir prazer em situações que anteriormente eram agradáveis e prazerosas. Apesar dos inúmeros estudos, a neurobiologia e a fisiopatologia dos transtornos depressivos ainda não são completamente conhecidas. Vários fatores têm sido sugeridos como importantes para o desenvolvimento da depressão, tais como exposição ao estresse (MENARD; PFAU; HODES; RUSSO, 2017), predisposição genética (LOHOFF, 2010), alterações no eixo HHA (CHEN; WANG; ZHANG; ZUO et al., 2016), nos níveis de neurotransmissores (principalmente monoaminas) (DELGADO, 2000; PYTKA; PODKOWA; RAPACZ; PODKOWA et al., 2016) e de fatores neurotróficos (KAREGE; PERRET; BONDOLFI; SCHWALD et al., 2002), bem como neuroinflamação (HUANG; LIN, 2015; MAES; YIRMYIA; NORABERG; BRENE et al., 2009; MENARD; PFAU; HODES; RUSSO, 2017).

Sabe-se que estressores físicos e psicológicos podem ativar o sistema imunológico e desencadear processos inflamatórios. A partir disso, na década de 80, a relação entre inflamação, 
mediadores do sistema imune e depressão foi sugerida pela primeira vez (ADER; COHEN, 1993; MAES, 1995; MAIER; WATKINS; FLESHNER, 1994; TECOMA; HUEY, 1985). Desde então muitas evidências têm apoiado a hipótese neuroinflamatória dos transtornos depressivos (IWATA; OTA; DUMAN, 2013; LISBOA; GOMES; GUIMARAES; CAMPOS, 2016). Estudos post-mortem em indivíduos depressivos que cometeram suicídio demonstram aumento da ativação de micróglias e acúmulo de macrófagos na região do córtex cingulado anterior (TORRES-PLATAS; CRUCEANU; CHEN; TURECKI et al., 2014). Além disso, diversos estudos indicam que a exposição a estressores incontroláveis e inescapáveis produz alterações neuroinflamatórias (ativação de células da micróglia, aumento e diminuição de citocinas pró- e anti-inflamatórias, respectivamente), indicando uma possível relação causal entre um reconhecido fator etiológico da depressão (estresse incontrolável) e sua fisiopatologia.

Sugere-se que a produção exacerbada de citocinas pró-inflamatórias seja crucial para as interações entre os sistemas nervoso central e imunológico nos transtornos depressivos (DOWLATI; HERRMANN; SWARDFAGER; LIU et al., 2010; IWATA; OTA; DUMAN, 2013; MAES, 1995; MAIER; WATKINS; FLESHNER, 1994). De fato, existem evidências que pacientes depressivos possuem aumento nos níveis plasmáticos de importantes citocinas próinflamatórias, como interleucinas (IL)-1 $\beta$, IL-6 e fator de necrose tumoral-alfa (TNF- $\alpha$ ), e que o tratamento com antidepressivos atenua tais alterações (ADER; COHEN, 1993; DOWLATI; HERRMANN; SWARDFAGER; LIU et al., 2010; HANNESTAD; DELLAGIOIA; BLOCH, 2011; HOWREN; LAMKIN; SULS, 2009; LEO; DI LORENZO; TESAURO; RAZZINI et al., 2006; LEVINE; BARAK; CHENGAPPA; RAPOPORT et al., 1999; SUTCIGIL; OKTENLI; MUSABAK; BOZKURT et al., 2007; THOMAS; DAVIS; MORRIS; JACKSON et al., 2005). É descrito, por exemplo, que indivíduos com comportamentos suicidas apresentam aumento nos níveis de IL-6 no líquido cefalorraquidiano (LINDQVIST; JANELIDZE; HAGELL; ERHARDT et al., 2009) e plasma (JANELIDZE; MATTEI; WESTRIN; TRASKMAN-BENDZ et al., 2011), enquanto em roedores, comportamentos tipo-depressivos são relacionados ao aumento desta 
citocina no hipocampo (MONJE; CABATIC; DIVISCH; KIM et al., 2011) e córtex (SUKOFF RIZZO; NEAL; HUGHES; BEYNA et al., 2012). Kong e colaboradores (2015) demonstraram que a ativação de STAT-3, um fator de transcrição relacionado à sobrevivência celular, produzida por IL-6 é importante para indução de comportamentos tipo-depressivos em roedores e para a regulação dos níveis do transportador de serotonina (SERT) em cultura de células (KONG; SUCIC; MONJE; SAVALLI et al., 2015).

A exposição de humanos (PANDEY; DWIVEDI, 2012; PANDEY; RIZAVI; REN; FAREED et al., 2012) e animais experimentais (ALCOCER-GOMEZ; ULECIA-MORON; MARIN-AGUILAR; RYBKINA et al., 2016; YOU; LUO; ZHANG; CHEN et al., 2011) a agentes estressores induz a expressão e produção central da citocina pró-inflamatória IL-1 $\beta$, que medeia diversos efeitos comportamentais, neuroendócrinos e plásticos desencadeados pelo estresse (ALCOCER-GOMEZ; ULECIA-MORON; MARIN-AGUILAR; RYBKINA et al., 2016; GOSHEN; KREISEL; BEN-MENACHEM-ZIDON; LICHT et al., 2008; ZHANG; LIU; LIU; SHEN et al., 2015). Dentre estes efeitos, destacam-se a modulação da atividade do eixo HHA e inibição da neurogênese hipocampal, dois fatores associados à fisiopatologia da depressão (IWATA; OTA; DUMAN, 2013; KOO; DUMAN, 2008). Em concordância com estas observações, Goshen e colaboradores (2008) verificaram que a exposição de camundongos ao modelo do estresse crônico imprevisível (chronic unpredictable stress, CUS) leva à diminuição na preferência pela sacarose, redução da exploração social, hiperativação adrenocortical e aumento nos níveis periféricos e hipocampais de IL-1 $\beta$. Já animais com deleção gênica do receptor de IL-1 ou que superexpressam o antagonista do receptor de IL-1 (IL-1Ra), não apresentaram essas alterações (GOSHEN; KREISEL; BEN-MENACHEM-ZIDON; LICHT et al., 2008). De modo similar, Koo \& Duman (2008) observaram que ratos submetidos ao CUS têm a redução da preferência pela sacarose bloqueada pela administração repetida do IL-1Ra (KOO; DUMAN, 2008). Além disso, a administração exógena de IL-1 (central e periférica) induz comportamentos tipo-depressivos em roedores, sendo estes comportamentos atenuados pelo 
tratamento crônico com drogas antidepressivas (CASTANON; BLUTHE; DANTZER, 2001; MERALI; BRENNAN; BRAU; ANISMAN, 2003), pré-tratamento com antagonistas de receptores para citocinas e, ainda, pela manipulação nos genes da família IL-1 (DANTZER, 2001a; b). Corroborando os achados em animais de laboratório, inúmeros estudos clínicos evidenciam que os níveis séricos e no líquido cefalorraquidiano de IL-1 $\beta$ estão aumentados em pacientes depressivos e que estes, inclusive, podem ser correlacionados com a gravidade, a duração e a idade de início do transtorno (ANISMAN; RAVINDRAN; GRIFFITHS; MERALI, 1999; OWEN; ECCLESTON; FERRIER; YOUNG, 2001; SCHIEPERS; WICHERS; MAES, 2005; THOMAS; DAVIS; MORRIS; JACKSON et al., 2005). Também já foi demonstrado que IL-1 $\beta$ aumenta a expressão do SERT em cultura de células (RAMAMOORTHY; RAMAMOORTHY; PRASAD; BHAT et al., 1995) e que tanto TNF quanto IL-1 $\beta$ levam à ativação desse transportador de forma rápida (ZHU; BLAKELY; HEWLETT, 2006). Estes efeitos, portanto, poderiam levar à diminuição dos níveis extracelulares de serotonina (5-HT) e favorecer o desenvolvimento do quadro depressivo.

\subsection{Ansiedade}

A ansiedade e o medo são emoções de grande importância evolutiva que permitem ao organismo evitar ou reduzir danos e, assim, garantir sobrevivência. Inúmeras espécies animais apresentam comportamentos relacionados a medo e ansiedade, evidenciando a relevância e a conservação destes para a manutenção das espécies. A resposta fisiológica e emocional à uma ameaça real, bem definida e imediata caracteriza o medo; enquanto que a ansiedade é a antecipação de uma ameaça em potencial, incerta ou desconhecida (CANTERAS; RESSTEL; BERTOGLIO; CAROBREZ ADE et al., 2010; DUNSMOOR; PAZ, 2015; LUTZ; MARSICANO; MALDONADO; HILLARD, 2015; TOVOTE; FADOK; LUTHI, 2015). Ambos, ansiedade e medo, são respostas oriundas do sistema cerebral de defesa, composto por estruturas límbicas, como amígdala, hipocampo, tálamo, hipotálamo e substância cinzenta periaquedutal, as quais, por sua vez, se conectam direta ou indiretamente com a região cortical (BLANCHARD; 
BLANCHARD; GRIEBEL，2005; BLANCHARD; BLANCHARD， 1989; CANTERAS; RESSTEL; BERTOGLIO; CAROBREZ ADE et al., 2010; TOVOTE; FADOK; LUTHI, 2015).

Inúmeros estudos evidenciam que a eficiência de desempenho em seres humanos está bastante relacionada aos níveis de ansiedade e estresse, de modo que níveis extremos são relacionados com baixa eficiência, enquanto níveis ideais elevam ou mantem a eficiência de desempenho (CALABRESE, 2008; CHABY; SHERIFF; HIRRLINGER; BRAITHWAITE, 2015; SHI; SHARPE; ABBOTT, 2019; WALDHAUSER; JOHANSSON; BACKSTROM; MECKLINGER, 2011). Quando existem alterações na percepção, interpretação, processamento e nas respostas fisiológicas oriundas de medo e ansiedade, bem como no tempo de duração desses eventos, esse quadro pode passar a ser mal adaptativo (TOVOTE; FADOK; LUTHI, 2015).

Nesse sentido, os transtornos de ansiedade possuem, como principais características, alterações comportamentais, neuroendócrinas, neuroanatômicas e de neurotransmissoras relacionadas ao medo e ansiedade. As situações que induzem as reações de medo e ansiedade são responsáveis pela diferenciação dos transtornos entre si. Portanto, embora eles sejam altamente correlacionáveis, a identificação das situações e objetos que deflagram as reações fisiológicas e comportamentais, permite a diferenciação dos casos (APA, 2013).

Dentre os principais transtornos de ansiedade, destacam-se os de separação, ansiedade generalizada, ansiedade social, pânico, agorafobia e fobias específicas. Além da alta taxa de comorbidade entre si, os transtornos de ansiedade também se correlacionam amplamente com outros transtornos mentais como os alimentares, depressivos, psicóticos, obsessivo-compulsivo, relacionados a trauma e estresse (APA, 2013).

Assim como em outros transtornos mentais, inúmeros sistemas neurotransmissores e neuromoduladores parecem estar envolvidos na fisiopatologia dos transtornos de ansiedade, como glutamatérgico, GABAérgico, serotoninérgico, nitrérgico e endocanabinoide. Além disso, deve ser destacado o papel do eixo HHA e do sistema imunológico (CANTERAS; RESSTEL; 
BERTOGLIO; CAROBREZ ADE et al., 2010; DUNSMOOR; PAZ, 2015; RAY; GULATI; RAI, 2017; SANDFORD; ARGYROPOULOS; NUTT, 2000; TOVOTE; FADOK; LUTHI, 2015).

Em estudos clínicos, pacientes com diagnóstico para transtornos de ansiedade apresentam níveis elevados de citocinas pró-inflamatórias em comparação com indivíduos saudáveis (COSTELLO; GOULD; ABROL; HOWARD, 2019; RAY; GULATI; RAI, 2017). Além disso, a indução da resposta imunológica, através da injeção de toxinas, induz comportamentos relacionados à ansiedade em humanos (REICHENBERG; YIRMIYA; SCHULD; KRAUS et al., 2001).

Já em animais experimentais, o estresse por derrota social induz o fenótipo tipo-ansioso em camundongos e esse efeito é dependente de ativação de micróglias que, por sua vez, induzirão o recrutamento de monócitos com perfil pró-inflamatório (produtores de IL-1 $\beta$ ) e resistentes aos GC, para a microvasculatura de regiões cerebrais envolvidas nas respostas ao estresse (MCKIM; WEBER; NIRAULA; SAWICKI et al., 2018; STARK; AVITSUR; PADGETT; CAMPBELL et al., 2001; WOHLEB; HANKE; CORONA; POWELL et al., 2011; WOHLEB; POWELL; GODBOUT; SHERIDAN, 2013).

Ratos submetidos ao protocolo de estresse crônico imprevisível também apresentam alterações comportamentais relacionadas à ansiedade e depressão. Esses efeitos são mediados pela ativação microglial na região do hipocampo, da via do inflamassoma de NLRP3 e do aumento da expressão de citocinas pró-inflamatórias - IL-1 $\beta$, IL-6 e IL-18 - e anti-inflamatórias, como IL-4 e IL-10. Ainda nesse sentido, o tratamento repetido com minociclina previne a ativação das micróglias, assim como as alterações comportamentais induzidas pelo estresse crônico (ZHANG; ZHANG; LI; LIU et al., 2019). 


\subsection{Transtorno de estresse pós-traumático}

O transtorno de estresse pós-traumático (post traumatic stress disorder, PTSD) é um transtorno psiquiátrico desenvolvido após exposição única ou repetida a eventos estressantes e/ou traumáticos - como desastres naturais, acidentes automobilísticos, guerras, ataques terroristas, violências física e/ou sexual, assaltos e sequestros, dentre outros (LAPIZ-BLUHM; PETERSON, 2014)(APA, 2013).

Os níveis de prevalência mundial deste transtorno são de difícil estimativa, uma vez que variam bastante de acordo com a população e países avaliados; porém acredita-se que estejam entre 3.5 e 7\% (KOENEN; RATANATHARATHORN; NG; MCLAUGHLIN et al., 2017). Esta condição pode ocorrer em qualquer idade e impacta negativamente a vida do indivíduo acometido, visto que está associado a altos índices de incapacidade social, ocupacional e física. Além disso, possui elevado grau de comorbidade com outros transtornos mentais, como depressão e ansiedade (APA, 2013)(KESSLER; HEERINGA; LAKOMA; PETUKHOVA et al., 2008; KESSLER; WANG, 2008; KOENEN; RATANATHARATHORN; NG; MCLAUGHLIN et al., 2017; YEHUDA; HOGE; MCFARLANE; VERMETTEN et al., 2015).

O critério essencial para diagnóstico é o desenvolvimento ou exacerbação da sintomatologia após a exposição ao trauma. A apresentação clínica do PTSD pode variar individualmente e até mesmo com o tempo em um único indivíduo, porém deve ter duração mínima de 30 dias. De maneira geral, existem 4 grandes conjuntos de sintomas característicos: 1) intrusão (memórias intrusivas involuntárias, pesadelos, flashbacks e angústia após a exposição a estímulos relacionados ao trauma); 2) prevenção/evitação (evasão de lembranças externas e pensamentos relacionados ao trauma); 3) alterações negativas de humor e cognição (inabilidade em relembrar pontos importantes do trauma, pensamentos e emoções negativas persistentes e recorrentes, alienação e inabilidade em experimentar emoções positivas). As alterações de 4) excitação e reatividade, incluem a hipervigilância, problemas de concentração, insônia, 
irritabilidade, imprudência e agressividade (LAPIZ-BLUHM; PETERSON, 2014; MENDOZA; BARRETO; AVILA-RODRIGUEZ; ECHEVERRIA, 2016)(APA, 2013).

A neurobiologia e fisiopatologia do PTSD são bastante complexas, multifatoriais e, portanto, de difícil entendimento. Sabe-se, no entanto, que alterações em áreas encefálicas e em sistemas de neurotransmissores intimamente ligados ao processamento do medo podem contribuir para a má adaptação ao evento traumático, resultando em alterações no aprendizado e na extinção de tais eventos aversivos (STECKLER; RISBROUGH, 2012). Estudos em humanos evidenciam anormalidades córtico-límbicas (MILAD; QUIRK, 2012; STECKLER; RISBROUGH, 2012). Sabe-se, por estudos de ressonância magnética funcional, que a ativação da amígdala está relacionada com respostas de medo condicionado em humanos (LABAR; GATENBY; GORE; LEDOUX et al., 1998; PHELPS; DELGADO; NEARING; LEDOUX, 2004; QUIRK; MUELLER, 2008; RABINAK; ANGSTADT; LYONS; MORI et al., 2014). Já o córtex préfrontal (CPF), particularmente a porção ventromedial (CPFvm), que se conecta com a amígdala, é importante para a consolidação de memórias de extinção, visto que atenua as respostas de medo condicionado por provável inibição da amígdala (MILAD; QUIRK, 2012; PHELPS; DELGADO; NEARING; LEDOUX, 2004). O hipocampo (HIP), assim como o CPFvm, também está associado positivamente à aquisição da extinção da memória aversiva (KALISCH; KORENFELD; STEPHAN; WEISKOPF et al., 2006; MILAD; WRIGHT; ORR; PITMAN et al., 2007; RABINAK; ANGSTADT; LYONS; MORI et al., 2014). Entretanto, em indivíduos com PTSD, enquanto a amígdala encontra-se hiperativa, o que justificaria a resposta exacerbada a eventos aversivos, o CPF está hipoativo e o HIP apresenta, além de hipoatividade, redução de volume e de integridade neuronial (SHIN; RAUCH; PITMAN, 2006; VANELZAKKER; DAHLGREN; DAVIS; DUBOIS et al., 2014). O déficit na sinalização entre o HIP e CPF pode levar a uma falha no controle contextual de respostas de medo condicionado (ACHESON; FORSYTH; MOSES, 2012). Além disso, o déficit no controle da atividade da amígdala pelo CPFvm prejudica o controle de resposta de medo (AUPPERLE; MELROSE; STEIN; PAULUS, 2012), 
particularmente na extinção de memórias relacionadas a este (KOENIGS; GRAFMAN, 2009; MILAD; PITMAN; ELLIS; GOLD et al., 2009). Desse modo, estas estruturas estão envolvidas em diferentes fases do desenvolvimento do TEPT, podendo atuar na aquisição da memória aversiva inicial, na manutenção das memórias e respostas de medo ou na extinção das mesmas (STECKLER; RISBROUGH, 2012).

Dentre os sistemas neurotransmissores e/ou neuromoduladores possivelmente envolvidos no desenvolvimento e manutenção do PTSD, estão os GABAérgico, glutamatérgico, noradrenérgico, nitrérgico, serotoninérgico e canabinoide (KAPLAN; MOORE, 2011; STECKLER; RISBROUGH, 2012). Evidências importantes também sugerem o envolvimento do eixo HHA (YEHUDA; TEICHER; TRESTMAN; LEVENGOOD et al., 1996). Já foi demonstrado, em pacientes, diminuição nos níveis de cortisol, elevação nos níveis de hormônio liberador de corticotrofina (CRH), aumento da responsividade de GR e maior sensibilidade ao feedback negativo (ROHLEDER; JOKSIMOVIC; WOLF; KIRSCHBAUM, 2004; YEHUDA; BOISONEAU; LOWY; GILLER, 1995; YEHUDA; HOGE; MCFARLANE; VERMETTEN $e t$ al., 2015; YEHUDA; SOUTHWICK; NUSSBAUM; WAHBY et al., 1990; YEHUDA; TEICHER; TRESTMAN; LEVENGOOD et al., 1996; ZOLADZ; DIAMOND, 2013). Nesse sentido, o aumento da resposta autonômica, devido à hiperatividade noradrenérgica central, e a hipoatividade do eixo HHA estão dentre as alterações biológicas mais bem estabelecidas e reproduzidas no PTSD (DASKALAKIS; COHEN; NIEVERGELT; BAKER et al., 2016; GERACIOTI; BAKER; EKHATOR; WEST et al., 2001; HENDRICKSON; RASKIND, 2016; PERI; BEN-SHAKHAR; ORR; SHALEV, 2000).

Além de alterações químicas e endócrinas, nos últimos anos o sistema imunológico tem sido bastante estudado e ganhado enfoque na fisiopatologia do PTSD (HORI; KIM, 2019; MENDOZA; BARRETO; AVILA-RODRIGUEZ; ECHEVERRIA， 2016; PASSOS; VASCONCELOS-MORENO; COSTA; KUNZ et al., 2015). A grande maioria dessas evidências derivam primariamente de estudos que avaliaram os níveis sistêmicos de mediadores 
inflamatórios em pacientes (HORI; KIM, 2019). Entretanto, estudos que investigaram metilação global (UDDIN; AIELLO; WILDMAN; KOENEN et al., 2010), transcriptoma sanguíneo (BREEN; TYLEE; MAIHOFER; NEYLAN et al., 2018; NEYLAN; SUN; REMPEL; ROSS et al., 2011) e análise de genoma global (STEIN; CHEN; URSANO; CAI et al., 2016) identificaram que genes e vias relacionadas à inflamação e ao sistema imune são as mais desreguladas em pacientes com PTSD em comparação com controles.

Diversos estudos demonstram que pacientes com esse transtorno apresentam aumento nos níveis séricos de citocinas pró-inflamatórias, como IL- $1 \beta$, TNF- $\alpha$, IL-6; de modo que esta última é a mais bem estudada e com resultados mais consistentes em estudos de meta-análise (HORI; KIM, 2019). Entretanto, existem estudos ainda que não encontraram alterações nos níveis de citocinas em pacientes com e sem PTSD (HORI; KIM, 2019) ou, então, que sugerem que a exposição ao trauma em si é suficiente para induzir a produção de mediadores inflamatórios, independentemente da ausência ou presença do quadro psiquiátrico (TURSICH; NEUFELD; FREWEN; HARRICHARAN et al., 2014). Essas variações podem estar relacionadas a heterogeneidade dos quadros deste transtorno, como por exemplo, o alto índice de comorbidade com outras condições psiquiátricas (HORI; KIM, 2019).

Devido à escassez de estudos longitudinais, a avalição de causa-consequência entre mecanismos inflamatórios e o estabelecimento do quadro de PTSD ainda é bastante complexa. Inúmeros são os mecanismos propostos para essa interação. Diante disso, um dos mecanismos propostos é o de que o estresse aumente os níveis de CRH que, por sua vez, estimulará o sistema nervoso autônomo simpático a produzir e liberar catecolaminas, principalmente a noradrenalina (HORI; KIM, 2019). Este neurotransmissor irá induzir a via de NFkB a produzir citocinas próinflamatórios, como IL-1 e IL-6 (BIERHAUS; WOLF; ANDRASSY; ROHLEDER et al., 2003); entretanto, outros mecanismos podem estar envolvidos além da via de NFkB (TAN; NACKLEY; SATTERFIELD; MAIXNER et al., 2007). Essas citocinas, estimulam ainda mais a liberação de CRH hipotalâmico (BAKER; WEST; NICHOLSON; EKHATOR et al., 1999; BREMNER; 
LICINIO; DARNELL; KRYSTAL et al., 1997). Considerando a hipótese anti-inflamatória clássica mediada pelo cortisol, através da supressão de NFkB (DE BOSSCHER; VANDEN BERGHE; HAEGEMAN, 2003) e regulação da apoptose celular (AMSTERDAM; SASSON, 2002), a hipocortisolemia clássica observada nos pacientes com PTSD pode levar a exacerbação do estado pró-inflamatório.

\subsection{Micróglias}

As micróglias são as células do sistema imune inato residentes no SNC, representam aproximadamente 5-10\% de toda a população celular central (FROST; SCHAFER, 2016) e são derivadas de progenitores de saco vitelínico que migram para essa região durante o período embrionário. A migração continua até a formação completa da barreira hematoencefálica. Portanto, possuem origem embrionária diferente das populações mieloides periféricas, uma vez que não dependem de progenitores sanguíneos derivados da medula óssea e nem de monócitos circulantes, mas sim da reserva original de precursores derivados do saco vitelínico no SNC. Diante disso, são consideradas células autorrenováveis e de longa duração (GINHOUX; GRETER; LEBOEUF; NANDI et al., 2010; GOMEZ PERDIGUERO; KLAPPROTH; SCHULZ; BUSCH et al., 2015; HASHIMOTO; CHOW; NOIZAT; TEO et al., 2013; KIERDORF; ERNY; GOLDMANN; SANDER et al., 2013; SCHULZ; GOMEZ PERDIGUERO; CHORRO; SZABOROGERS et al., 2012; SHENG; RUEDL; KARJALAINEN, 2015; TAY; MAI; DAUTZENBERG; FERNANDEZ-KLETT et al., 2017).

Uma das principais e mais clássicas funções atribuídas às micróglias é a de ser a primeira linha de defesa contra danos teciduais e infecções por patógenos no SNC, orquestrando a resposta imune, através da produção de quimiocinas, citocinas e de processos como reconhecimento, fagocitose e apresentação de antígeno (HANISCH; KETTENMANN, 2007; PRINZ; PRILLER, 2014; RANSOHOFF; PERRY, 2009). Entretanto, essas células também regulam uma série de processos fisiológicos fundamentais para desenvolvimento e homeostasia do SNC, como poda 
sináptica, neuroplasticidade, morte celular programada, remodelamento celular e estrutural, bem como limpeza de debris, dentre outros (CALCIA; BONSALL; BLOOMFIELD; SELVARAJ et al., 2016; GOMES-LEAL, 2012; MONDELLI; VERNON; TURKHEIMER; DAZZAN et al., 2017).

Um importante marcador para identificação de micróglias é a molécula adaptadora de ligação ao cálcio ionizado-1 (Ionized calcium binding adaptor molecule 1, Iba-1), amplamente utilizado por conta da especificidade e expressão por micróglias em todos os estados de ativação. Entretanto, macrófagos infiltrados no SNC também podem passar a expressar Iba-1. Além dele, existem outros marcadores de superfície celular que permitem a diferenciação dos estados da micróglia (ativo ou vigilante) e, até mesmo, de outras populações celulares como macrófagos e células dendríticas. Em geral, micróglias apresentam o fenótipo $\mathrm{CD} 45^{\text {low }}, \mathrm{CD} 11 \mathrm{~b}^{+}, \mathrm{CD}_{115^{+}}$, MHCII', CD11c', CCR2 ${ }^{\text {low }}$ e CX3CR1 $1^{\text {high }}$ quando no estado de vigilância (“inativo") e, quando ativadas, podem ter expressão diferencial desses marcadores (CALCIA; BONSALL; BLOOMFIELD; SELVARAJ et al., 2016; FRICK; WILLIAMS; PITTENGER, 2013).

As micróglias são células do parênquima que respondem rapidamente a pequenas alterações centrais. Em condições saudáveis, possuem morfologia ramificada, caracterizadas por processos longos e finos que permitem a vigilância do microambiente. Já em situações nãofisiológicas, essas células são ativadas por meio dos receptores de reconhecimento padrão (RRP) e rapidamente sofrem modificações conformacionais, adquirindo o perfil ameboide caracterizado pela hipertrofia do corpo celular e ramificação, apesar do encurtamento, dos prolongamentos (CALCIA; BONSALL; BLOOMFIELD; SELVARAJ et al., 2016; MONDELLI; VERNON; TURKHEIMER; DAZZAN et al., 2017). Ainda nessa fase, entram em processo de expansão clonal e produzem mediadores responsáveis pelo recrutamento de outras células do sistema imune ao SNC (GOMES-LEAL, 2012; TAY; MAI; DAUTZENBERG; FERNANDEZ-KLETT et al., 2017). A produção de citocinas pró-inflamatórias e expressão de 
antígenos/marcadores na superfície celular também são características da resposta inflamatória mediada por micróglias. Em situações de estresse crônico, pode ocorrer hipertrofia dos processos e o corpo celular se manter aumentado. Parte dessas alterações já foram descritas não apenas em resposta a estímulos inflamatórios clássicos, mas também a estressores psicológicos (CALCIA; BONSALL; BLOOMFIELD; SELVARAJ et al., 2016; IWATA; OTA; DUMAN, 2013; LISBOA; GOMES; GUIMARAES; CAMPOS, 2016; LISBOA; NIRAULA; RESSTEL; GUIMARAES et al., 2018).

Previamente, estudos buscavam diferenciar os perfis de ativação microglial, dependendo da natureza dos estímulos imunológicos aos quais essas células eram expostas; nesse contexto, foram descritos os perfis M1 e M2. O fenótipo M1 estaria mais relacionado ao perfil próinflamatório e citotóxico dessas células, uma vez que a diferenciação ocorreria no microambiente de citocinas pró-inflamatórias quando na presença de antígenos, como por exemplo LPS. Já o segundo perfil, M2, seria induzido em microambiente de citocinas reguladoras e antiinflamatórias para contrapor as respostas inflamatórias. Portanto, segundo esse critério de definição, micróglias diferenciadas poderiam desempenhar funções citotóxicas ou neuroprotetoras/reguladoras. Essa classificação, atualmente, vem sendo revista, uma vez que foi desenvolvida baseada principalmente em estudos in vitro que não foram passíveis de reprodução in vivo ou que utilizavam macrófagos periféricos. Portanto, atualmente, sugere-se que o fenótipo e perfil dessas células podem variar ao longo do tempo (CRAIN; NIKODEMOVA; WATTERS, 2013; DAVALOS; GRUTZENDLER; YANG; KIM et al., 2005; ESTES; MCALLISTER, 2014; MONDELLI; VERNON; TURKHEIMER; DAZZAN et al., 2017; NORDEN; TROJANOWSKI; VILLANUEVA; NAVARRO et al., 2016; RANSOHOFF, 2016; TANG; LE, 2016).

Inúmeras evidências pré-clínicas, clínicas e post mortem têm sugerido a participação de micróglias na fisiopatologia de diversas condições médicas - transtornos de desenvolvimento (autismo) e mentais (esquizofrenia, ansiedade, depressão, dentre outros), doenças 
neurodegenerativas (Alzheimer, Parkinson, esclerose lateral amniotrófica, dentre outros), neuropatias, dentre outras (CALCIA; BONSALL; BLOOMFIELD; SELVARAJ et al., 2016; GOMES-LEAL, 2012; IWATA; OTA; DUMAN, 2013; LISBOA; GOMES; GUIMARAES; CAMPOS, 2016; MONDELLI; VERNON; TURKHEIMER; DAZZAN et al., 2017).

No âmbito de estudos pré-clínicos que avaliam a fisiopatologia de transtornos mentais, é amplamente descrito na literatura que estressores psicossociais aumentam a expressão de Iba-1 principalmente no córtex e hipocampo de roedores (ALCOCER-GOMEZ; ULECIA-MORON; MARIN-AGUILAR; RYBKINA et al., 2016; CALCIA; BONSALL; BLOOMFIELD; SELVARAJ et al., 2016; IWATA; OTA; DUMAN, 2013; PAN; CHEN; ZHANG; KONG, 2014). Considerando o fato de que o estresse é amplamente relacionado com o desenvolvimento de transtornos psiquiátricos, através de múltiplos mecanismos, incluindo mecanismos imunológicos, as células da micróglia despontam como principais mediadores desse processo.

Sabe-se que a resposta imune sofre variações de acordo com a duração, frequência e intensidade de exposição ao estresse (MCEWEN, 2000). Inúmeros são os mecanismos sugeridos para esses efeitos, como por exemplo a alta taxa de expressão de receptores glicocorticoides e mineralocorticoides tanto em micróglias (SIERRA; GOTTFRIED-BLACKMORE; MILNER; MCEWEN et al., 2008), quanto em regiões de alta densidade microglial e importantes para o desenvolvimento de transtornos mentais, como CPF e HIP (ARONSSON; FUXE; DONG; AGNATI et al., 1988; DIORIO; VIAU; MEANEY, 1993; GOLD, 2015; MCEWEN; GOULD; SAKAI, 1992). Além disso, as micróglias, são consideradas as principais contribuintes para processos inflamatórios no cérebro, uma vez que - juntamente com os astrócitos - produzem uma ampla quantidade de citocinas (TNF- $\alpha$, IL-6, IL-18 e IL-1 $\beta$ ) no SNC (CALCIA; BONSALL; BLOOMFIELD; SELVARAJ et al., 2016; KIM; KIM; YENARI, 2015; RANSOHOFF; BROWN, 2012). Interleucina $1 \beta$ é considerada um dos mais potentes agentes neuroinflamatórios, com ação pirógena, antineurogênica, antiplasticidade e indutora de comportamentos tipo- 
depressivos e tipo-ansiogênicos (ALCOCER-GOMEZ; ULECIA-MORON; MARINAGUILAR; RYBKINA et al., 2016; GOSHEN; KREISEL; BEN-MENACHEM-ZIDON; LICHT et al., 2008; IWATA; OTA; DUMAN, 2013; KOO; DUMAN, 2008; LIU; QUAN, 2018; ZHANG; LIU; LIU; SHEN et al., 2015). A transcrição e função de IL-1 $\beta$ dependem da ativação da via de NFkB (fator nuclear kB) e inflamassoma de NLRP3 (HANEKLAUS; O'NEILL; COLL, 2013; MARTINON; BURNS; TSCHOPP, 2002), um receptor de reconhecimento padrão que será melhor descrito na próxima sessão.

\subsection{Receptores de reconhecimento padrão, inflamassoma de NLRP3 e transtornos mentais}

Os receptores de reconhecimento padrão (RRP) compõem uma família de receptores da imunidade inata que sinalizam em resposta a padrões moleculares associados ao dano (Damageassociated molecular pattern, DAMPs) e a patógenos (Pathogen-associated molecular pattern, PAMPs). A primeira classe de RRP a ser identificada e, por consequência, a mais estudada, é a dos receptores do tipo Toll (Toll-like receptors, TLRs) que são expressos nas superfícies celular e endossomal. Os receptores do tipo NOD (Nucleotide-binding oligomerization domain-like receptors, NLRs), dentre os quais um subtipo é o foco do presente trabalho, são receptores citosólicos e funcionam como sensores intracelulares (FRANCHI; WARNER; VIANI; NUNEZ, 2009; TAKEUCHI; AKIRA, 2010). Esses receptores são capazes de reconhecer inúmeros estímulos e sinais endógenos de perigo, como o acúmulo de cristais de ácido úrico (SHI; EVANS; ROCK, 2003), baixas concentrações de potássio intracelular (MARTINON, 2010), espécies reativas de oxigênio (ROS) e adenosina trifosfato (ATP) (IWATA; OTA; DUMAN, 2013; MARTINON; MAYOR; TSCHOPP, 2009; SCHRODER; ZHOU; TSCHOPP, 2010), além da proteína $\beta$-amiloide (HALLE; HORNUNG; PETZOLD; STEWART et al., 2008). Além disso, sua ativação pode ser diretamente induzida por receptores purinérgicos do subtipo 7 (P2X7) e receptores do tipo-Toll 2 e 4 que, por sua vez, estão envolvidos em processos inflamatórios 
relacionados ao estresse no SNC (BABELOVA; MORETH; TSALASTRA-GREUL; ZENGBROUWERS et al., 2009; WEBER; FRANK; SOBESKY; WATKINS et al., 2013).

Os NLRs apresentam uma estrutura característica composta por três domínios: um domínio carboxi-terminal LRR (leucine rich repeat); um domínio NOD, responsável pela oligomerização do receptor após sua ativação; e um domínio amino-terminal distinto, que desencadeia a função efetora do receptor (ATHMAN; PHILPOTT, 2004). Na ausência de estímulo, o NLR encontra-se em uma forma inativa e as regiões efetoras permanecem protegidas pela região LRR, o que bloqueia sua ativação. A ligação de moléculas ao LRR promove modificação estrutural no receptor, resultando na exposição dos sítios de ligação ao ATP, permitindo assim a ligação de ATP ao domínio NOD, o qual se oligomeriza e promove a sinalização celular característica de cada NLR (MARTINON; BURNS; TSCHOPP, 2002).

Um receptor NLR envolvido na ativação de IL-1 $\beta$ é o receptor NLRP3 (Nod-like receptor protein 3), considerado um mediador essencial para a função desta interleucina (HANEKLAUS; O'NEILL; COLL, 2013; MARTINON; BURNS; TSCHOPP, 2002), visto que induz a clivagem de pró-IL-1 $\beta$ (forma inativa pré-formada) em IL-1 $\beta$ ativa. Estímulos pró-inflamatórios iniciais levam à produção de pró-IL-1 $\beta$ e pró-IL-18 pela via de NFkB. O receptor NLRP3 requer a proteína adaptadora ASC (apoptosis-associated speck-like protein containing a CARD domain) para ativar pró-caspase-1 a caspase-1 (MARTINON; MAYOR; TSCHOPP, 2009), que por sua vez, é a responsável por clivar pró-IL-18 em IL-18 e pró-IL-1 $\beta$ em IL-1 $\beta$. O inflamassoma de NLRP3 é um complexo multiprotéico citosólico caracterizado pela oligomerização de NLRP3/ASC/caspase-1. Recentemente, a sua associação com importantes doenças crônicas, tais como Alzheimer (TAN; YU; JIANG; ZHU et al., 2013) e transtornos depressivos (IWATA; OTA; DUMAN, 2013) tem sido amplamente descrita. Estima-se que o inflamassoma de NLRP3 responda a perturbações nas membranas de células da imunidade inata e, sendo assim, é considerado um sensor de dano passível de ativação por DAMPs (MARTINON; MAYOR; TSCHOPP, 2009). Sabe-se que a via de NFkB e o inflamassoma de NLRP3, através da produção 
de IL-1 $\beta$, ativa o sistema imune inato e desencadeia respostas inflamatória (IWATA; OTA; DUMAN, 2013).

O inflamassoma de NLRP3 tem sido descrito como um potencial indutor da inflamação mediada por IL-1 $\beta$ no SNC (ALBORNOZ; WOODRUFF; GORDON, 2018; IWATA; OTA; DUMAN, 2013; WALSH; MURUVE; POWER, 2014; WONG; INSERRA; LEWIS; MASTRONARDI et al., 2016). Neste sentido, Alcocer-Gomez e colaboradores (2014) verificaram o aumento na expressão gênica de NLRP3, caspase-1 e de IL-1 $\beta$ plasmática em monócitos e linfócitos de pacientes com depressão maior (não tratados) em relação aos tratados com amitriptilina, um antidepressivo tricíclico (ALCOCER-GOMEZ; DE MIGUEL; CASASBARQUERO; NUNEZ-VASCO et al., 2014). Já em ratos submetidos ao protocolo do CUS por 12 semanas, observou-se redução da preferência pela sacarose e do peso corporal e aumento na expressão proteica de IL-1 $\beta$, NLRP3, caspase-1 ativa, P2X7 e TLR2 no CPF (PAN; CHEN; ZHANG; KONG, 2014). Além disso, o CUS induziu aumento na expressão de CD11b (integrina expressa em macrófagos e micróglias) e Iba-1, bem como diminuição de GFAP (marcador de astrócitos) no CPF. Houve, também, aumento da co-localização de NLRP3 e Iba-1, sugerindo a importância das micróglias para a ativação da plataforma do inflamassoma e inflamação induzida por IL-1 $\beta$ no CPF desses animais. Por fim, o tratamento repetido com fluoxetina (FLX antidepressivo inibidor seletivo da recaptação de 5-HT) preveniu os efeitos da exposição ao CUS em ratos (PAN; CHEN; ZHANG; KONG, 2014).

De modo semelhante, camundongos expostos ao CUS por 4 semanas apresentam comportamentos anedônicos e aumento nos níveis plasmáticos de GC e IL-1 $\beta$ bem como nos níveis proteicos de NLRP3, ASC, caspase-1 e de IL-1 $\beta$ ativas (ZHANG; LIU; LIU; SHEN et al., 2015). Corroborando a proposta de envolvimento de NLRP3 nas consequências comportamentais do estresse, Alcocer-Gomez e colaboradores (2015) observaram que animais knockout para o receptor NLRP3 não são suscetíveis às alterações comportamentais tipo-depressivas induzidas pela exposição ao estresse por restrição durante 7 dias. Além disso, apenas nos animais 
estressados tipo-selvagens o estresse aumentou a expressão gênica e proteica de NLRP3 e IL-1 $\beta$ no hipocampo (HIP) e de adenosina e ATP no HIP e CPF, bem como induzir ativação de micróglia nestas estruturas. Ainda nesse sentido, o tratamento com minociclina, um inibidor da ativação microglial, preveniu a ativação destas células, bem como o aumento da expressão de NLRP3 e IL-1 $\beta$ tanto no CPF quanto no HIP (ALCOCER-GOMEZ; ULECIA-MORON; MARINAGUILAR; RYBKINA et al., 2016).

\subsection{Eixo Hipotálamo-Hipófise-Adrenal e Glicocorticoides}

Neurônios da região paraventricular do hipotálamo (PVN) liberam o hormônio liberador de corticotrofina $(\mathrm{CRH})$ no sistema porta hipofisário que, por sua vez, estimula a adenohipófise a produzir e secretar o hormônio adrenocorticotrófico (ACTH) na circulação sistêmica. O ACTH, uma vez que atinge as células da zona fasciculada, na região do córtex da glândula adrenal, induz a síntese e liberação de GC, a partir da molécula do colesterol. Em seres humanos, o cortisol (hidrocortisona) é o principal GC, já em roedores é a corticosterona. Esse eixo é finamente controlado através de alças de retroalimentação negativa, cujo protagonista é o próprio cortisol, que inibe a liberação de CRH pelo hipotálamo e ACTH pela adeno-hipófise (CAIN; CIDLOWSKI, 2017; ILAHI; ILAHI, 2020; STEPHENS; WAND, 2012). A ativação hipotalâmica do eixo HPA, por sua vez, também pode ser diretamente modulada por diversos sistemas de neurotransmissão, como GABA, opioides, serotonina, acetilcolina e noradrenalina (STEPHENS; WAND, 2012).

A ação dos GC, em situações de estresse, se dá majoritariamente através dos GR, membros da família de receptores nucleares dos fatores de transcrição, e localizados no citoplasma celular predominante na conformação inativa. Uma vez que ocorre a ligação dos GC aos GR, há ativação, mudança conformacional, translocação nuclear, e ligação do receptor a regiões palindrômicas do DNA, normalmente presentes na região promotora de genes. Essas regiões contêm elementos de resposta aos glicocorticoides (GRE) ou elementos de resposta negativa aos glicocorticoides (nGRE). Eles permitem a transativação ou transrepressão de genes 
alvo, respectivamente. Desse modo, há especificidade na regulação de transcrição dos genes alvo induzida pelos GC. Pode haver, ainda, a ligação direta de GR a fatores de transcrição, como NFkB, ou a moléculas co-ativadoras ou co-repressoras. Por fim, parte dos efeitos dos GC ocorre através de mecanismos não-genômicos, consistindo basicamente em respostas rápidas que não envolvem modulação da expressão gênica direta ou indiretamente, ou seja, que não dependem de transcrição e síntese proteica. Em geral, esses efeitos são associados a GR ligados à membrana plasmática, aos canais iônicos controlando o fluxo de cálcio intracelular ou, até mesmo, atividade modulatória sobre a neurotransmissão glutamatérgica ou sistema endocanabinoide (BAIN; YANG; CONNAGHAN; ROBBLEE et al., 2012; DE BOSSCHER; VANDEN BERGHE; HAEGEMAN, 2003; DEJEAN; RICHARD，2013; FINSTERWALD; ALBERINI, 2014; LIBERMAN; DRUKER; PERONE; ARZT, 2007; MEIJSING; ELBI; LUECKE; HAGER et al., 2007; MEIJSING; PUFALL; SO; BATES et al., 2009; RASHID; LEWIS, 2005; RHEN; CIDLOWSKI, 2005; SMOAK; CIDLOWSKI, 2004; STELLATO, 2004; WEIKUM; KNUESEL; ORTLUND; YAMAMOTO, 2017).

Os GC regulam inúmeros processos fisiológicos essenciais para sobrevivência, como gliconeogênese, metabolismo proteico, metabolismo lipídico, funções cardiovasculares, proliferação e sobrevivência celulares e modulam respostas imunológicas, sendo amplamente caracterizados como agentes anti-inflamatórios e imunossupressores (CAIN; CIDLOWSKI, 2017; COUTINHO; CHAPMAN, 2011). No entanto, esses hormônios esteroidais também podem exercer ações pró-inflamatórias, aumentando a resposta imune em resposta ao LPS (FRANK; MIGUEL; WATKINS; MAIER, 2010) e potencializando o aumento nos níveis de expressão de TLR2 induzidos por TNF (HERMOSO; MATSUGUCHI; SMOAK; CIDLOWSKI, 2004).

O desbalanço na regulação das respostas ao estresse e subsequente secreção anormal de cortisol são associadas a psicopatologias, como transtornos de ansiedade, depressão e transtorno de estresse pós-traumático. A hiperativação do eixo HHA e consequente aumento nos níveis circulantes de GC já foi demonstrada em inúmeros trabalhos, tanto em pacientes depressivos 
quanto em animais experimentais expostos ao estresse (GOLD, 2015). Em casos de PTSD, a maioria dos estudos sugere hipofunção do eixo HHA, observado através dos níveis reduzidos de cortisol (YEHUDA; BOISONEAU; LOWY; GILLER, 1995; YEHUDA; HOGE; MCFARLANE; VERMETTEN et al., 2015; YEHUDA; SOUTHWICK; NUSSBAUM; WAHBY et al., 1990; YEHUDA; TEICHER; TRESTMAN; LEVENGOOD et al., 1996).

$\mathrm{Na}$ última década, os GC têm sido sugeridos como importantes moduladores do inflamassoma de NLRP3 - uma vez que aumentam de forma rápida e sustentada a expressão de NLRP3 em culturas de macrófagos humanos e de camundongos, além de elevarem a liberação de IL-1 $\beta$ ativa e sensibilizarem o inflamassoma de NLRP3 a concentrações extracelulares de ATP (BUSILLO; AZZAM; CIDLOWSKI, 2011). Ainda nesse contexto, ratos adrenalectomizados e tratados com corticosterona (CORT) durante 10 dias apresentam aumento na expressão gênica de NLRP3, Iba-1 e MHC-II em micróglias do HIP de modo dose-dependente, bem como aumento de mediadores pró-inflamatórios (IL-1 $\beta$, IL-6, TNF e NLRP3) em micróglias ativadas desafiadas com LPS (FRANK; HERSHMAN; WEBER; WATKINS et al., 2014). Recentemente, foi descrito que o estresse crônico por restrição é capaz de diminuir o peso corpóreo, induzir comportamentos tipo-depressivos e aumentar os níveis séricos de corticosterona em ratos. Na região do HIP, o estresse alterou a estrutura e disposição dos neurônios, diminuir a expressão de GR e da fração citosólica de NFkB (p65); assim como aumentou a expressão de células Iba-1 positivas, espécies reativas de oxigênio (ROS), fração nuclear de NFkB (p65) e de todos os componentes do inflamassoma de NLRP3 - NLRP3, ASC, Caspase-1, Caspase-1 p20, pró-IL1 $\beta$, IL-1 $\beta$ e IL-18. Para validar os resultados in vivo, os autores trataram a linhagem HAPI, células imortalizadas e oriundas de culturas primárias de micróglias obtidas de ratos neonatos, com dexametasona. Os resultados obtidos in vitro foram semelhantes aos in vivo, no que se refere à diminuição da expressão de GR e aumentos da formação de ROS, na expressão de Iba-1, NFkB, componentes do inflamassoma de NLRP3 e interleucinas $-1 \beta$ e -18 . O pré-tratamento com um inibidor de NFkB e a deleção gênica de NLRP3 nas células diminuiu os efeitos prévios da dexametasona; sugerindo 
que a ativação da via GR-NFkB-inflamassoma de NLRP3 em micróglias hipocampais exerce papel importante sobre comportamentos tipo-depressivos e processos neuroinflamatórios (FENG; ZHAO; YANG; SONG et al., 2019).

Desse modo, sugere-se, a partir do apresentado, que o eixo HHA e os GR podem exercer um papel modulatório importante sobre a via do inflamassoma de NLRP3 e, consequentemente, na fisiopatologia dos transtornos mentais.

\subsection{Canabidiol}

O canabidiol (CBD) é o principal constituinte não-psicotomimético da planta Cannabis sativa e possui ação sobre diversos receptores no $\mathrm{SNC}$, dentre eles os receptores canabinoides (CB) do tipo 1 e 2, GPR55 (G-protein coupled receptor 55), TRPV1 (transient receptor potential vanilloid type 1), PPAR- $\gamma$ e 5-HT1A (AHRENS; DEMIR; LEUWER; DE LA ROCHE et al., 2009; BISOGNO; HANUS; DE PETROCELLIS; TCHILIBON et al., 2001; CAMPOS; GUIMARAES，2008; 2009; CASAROTTO; GOMES; RESSTEL; GUIMARAES，2010; FOGACA; CAMPOS; COELHO; DUMAN et al., 2018; HARTMANN; LISBOA; SONEGO; COUTINHO et al., 2019; RESSTEL; TAVARES; LISBOA; JOCA et al., 2009; RUSSO; BURNETT; HALL; PARKER, 2005; RYBERG; LARSSON; SJOGREN; HJORTH et al., 2007; SONEGO; PRADO; VALE; SEPULVEDA-DIAZ et al., 2018; ZANELATI; BIOJONE; MOREIRA; GUIMARAES et al., 2010). Acredita-se que o mecanismo da interação do CBD com receptores $\mathrm{CB} 1$ e CB2 seja indireto, visto que este pode aumentar os níveis de anandamida (AEA) por inibir a enzima hidrolase amida de ácidos graxos (FAAH), responsável pelo metabolismo deste endocabinoide (BISOGNO; HANUS; DE PETROCELLIS; TCHILIBON et al., 2001). Os receptores CB1 são os receptores metabotrópicos mais expressos no cérebro de mamíferos (HERKENHAM; LYNN; LITTLE; JOHNSON et al., 1990) e se localizam em micróglias, astrócitos, oligodendrócitos (LISBOA; GOMES; GUIMARAES; CAMPOS, 2016) e na membrana pré-sináptica de neurônios, onde inibem a liberação de diversos neurotransmissores clássicos (EGERTOVA; GIANG; CRAVATT; ELPHICK, 1998). Já os receptores CB2, 
amplamente expressos em micróglias no $\mathrm{SNC}$, são considerados os principais receptores canabinoides envolvidos na modulação da resposta imune (LISBOA; GOMES; GUIMARAES; CAMPOS, 2016); uma vez que inibem a neuroinflamação por reduzir a produção de citocinas pró-inflamatórias e favorecem a diferenciação destas células para o perfil relacionado a mecanismos regulatórios (MECHA; FELIU; CARRILLO-SALINAS; RUEDA-ZUBIAURRE $e t$ al., 2015). De modo geral, os canabinoides e o sistema endocanabinoide têm sido bastante relacionados com a hipótese neuroinflamatória dos transtornos psiquiátricos, sendo as micróglias as principais células pelas quais estes poderiam desenvolver sua capacidade imunomoduladora no SNC (LISBOA; GOMES; GUIMARAES; CAMPOS, 2016).

Inúmeros estudos em modelos animais (CAMPOS; MOREIRA; GOMES; DEL BEL et al., 2012; CAMPOS; ORTEGA; PALAZUELOS; FOGACA et al., 2013; FOGACA; CAMPOS; COELHO; DUMAN et al., 2018; GOMES; DEL BEL; GUIMARAES, 2013; GOMES; LLORENTE; DEL BEL; VIVEROS et al., 2015; HARTMANN; LISBOA; SONEGO; COUTINHO et al., 2019; PEDRAZZI; ISSY; GOMES; GUIMARAES et al., 2015; RESSTEL; TAVARES; LISBOA; JOCA et al., 2009) e clínicos (CRIPPA; DERENUSSON; FERRARI; WICHERT-ANA et al., 2011; ZUARDI, 2008; ZUARDI; COSME; GRAEFF; GUIMARAES, 1993) sugerem que o CBD pode ter amplo uso terapêutico em diversos transtornos neuropsiquiátricos. Dentre estes, podem ser destacados a prevenção das alterações comportamentais induzidas pelo estresse por restrição agudo (RESSTEL; TAVARES; LISBOA; JOCA et al., 2009), os efeitos tipo-antidepressivo (ZANELATI; BIOJONE; MOREIRA; GUIMARAES et al., 2010), tipo-ansiolítico (GUIMARAES; CHIARETTI; GRAEFF; ZUARDI, 1990; MOREIRA; AGUIAR; GUIMARAES, 2006) e anti-compulsivo em modelos/testes animais (CASAROTTO; GOMES; RESSTEL; GUIMARAES, 2010). Recentemente, verificamos que a administração aguda de $\mathrm{CBD}$ atenua o comportamento agressivo induzido pelo isolamento social em camundongos, através de receptores CB1 e 5-HT1A (HARTMANN; LISBOA; SONEGO; COUTINHO et al., 2019). 
Apesar de a maioria dos efeitos farmacológicos agudos do CBD em modelos animais serem atribuídos à facilitação da neurotransmissão mediada por receptores 5HT1A ou CB1, mecanismos distintos podem estar envolvidos nos efeitos observados a partir do uso repetido da droga. Dentre estes, destacam-se, a prevenção dos efeitos plásticos induzidos pelo estresse crônico imprevisível, como diminuição da neurogênese hipocampal e do remodelamento dendrítico (AGUADO; MONORY; PALAZUELOS; STELlA et al., 2005; CAMPOS; ORTEGA; PALAZUELOS; FOGACA et al., 2013; FOGACA; CAMPOS; COELHO; DUMAN et al., 2018; JIANG; ZHANG; XIAO; VAN CLEEMPUT et al., 2005; PALAZUELOS; AGUADO; EGIA; MECHOULAM et al., 2006). Embora estes efeitos pareçam ser decorrentes de uma maior ação da AEA (CAMPOS; ORTEGA; PALAZUELOS; FOGACA et al., 2013), os mecanismos pelos quais a facilitação deste endocanabinoide preveniria os efeitos decorrentes da exposição ao estresse ainda são pouco claros. Uma das possibilidades seria a ação sobre as alterações neuroinflamatórias induzidas pelo estresse crônico.

O CBD possui propriedades anti-inflamatórias e imunossupressoras já descritas (ZUARDI, 2008). Quando administrado de forma aguda ou repetida, diminui citocinas próinflamatórias em inúmeros modelos murinos de desafio imunológico (BARICHELLO; CERETTA; GENEROSO; MOREIRA et al., 2012; BORRELli; AVIELLO; ROMANO; ORLANDO et al., 2009; CAMPOS; BRANT; MIRANDA; MACHADO et al., 2015; ESPOSITO; SCUDERI; SAVANI; STEARDO et al., 2007; MECHA; FELIU; INIGO; MESTRE et al., 2013; VUOLO; PETRONILHO; SONAI; RITTER et al., 2015), em culturas de micróglias e de células periféricas do sistema imune de humanos (SRIVASTAVA; SRIVASTAVA; BROUHARD, 1998). Além disso, o CBD aumenta os níveis de IL-10 (BORRELLI; AVIELLO; ROMANO; ORLANDO et al., 2009; ESPOSITO; SCUDERI; SAVANI; STEARDO et al., 2007; LIU; HU; HUANG; WEY et al., 2010; SRIVASTAVA; SRIVASTAVA; BROUHARD, 1998) uma importante citocina anti-inflamatória que, por sua vez, modula negativamente a via do inflamassoma de NLRP3 (GURUNG; LI; SUBBARAO MALIREDDI; LAMKANFI et al., 
2015). Ainda nesse sentido, Esposito e colaboradores evidenciaram que a administração sistêmica deste composto diminui a neuroinflamação induzida pela injeção intra-hipocampal da proteina $\beta$ amiloide por diminuir os níveis de IL-1 $\beta$ e da enzima óxido nítrico sintase induzida (iNOS) em camundongos (ESPOSITO; SCUDERI; SAVANI; STEARDO et al., 2007). Alguns mecanismos propostos para explicar os efeitos anti-inflamatórios do CBD incluem o controle da expressão da iNOS (ESPOSITO; SCUDERI; SAVANI; STEARDO et al., 2007), supressão da infiltração e ativação de macrófagos e células T (LIU; HU; HUANG; WEY et al., 2010), bem como a desregulação do fator nuclear de células T ativadas (NFAT) (KAPLAN; SPRINGS; KAMINSKI, 2008) e ativação de receptores PPAR-gama (SONEGO; PRADO; VALE; SEPULVEDA-DIAZ et al., 2018). Evidências recentes, no entanto, também têm sugerido que a interferência com a micróglia pode ser importante para os efeitos da administração repetida do CBD .

Em nosso laboratório, verificamos que o CBD previne o aumento na ativação de micróglias no CPF e HIP de camundongos em um modelo de esquizofrenia baseado no tratamento repetido com antagonista de receptores NMDA (GOMES; LLORENTE; DEL BEL; VIVEROS et al., 2015). Este foi um dos primeiros estudos relacionando os efeitos da administração repetida do CBD em modelo animal de transtorno mental e alterações na ativação de micróglias. Ainda nesse sentido, Sonego e colaboradores (2018) demonstraram que o tratamento repetido com haloperidol aumenta os níveis de IL-1 $\beta$ e tende a aumentar TNF- $\alpha$ na região do estriado, efeito este que é prevenido pela administração de CBD (60 mg/kg). De modo interessante, os tratamentos isolados (CBD ou haloperidol) não alteram os níveis de IL-10, porém a combinação das drogas aumentou os níveis desta citocina anti-inflamatória. O tratamento repetido com haloperidol aumentou a ativação de micróglias e esse efeito se correlaciona positivamente com as movimentos mastigatórios repetitivos induzidos por antipsicóticos, modelo animal de discinesia tardia orofacial. O pré-tratamento com CBD é capaz de diminuir a ativação microglial e prevenir a alteração comportamental, de modo que esse último efeito é bloqueado pelos antagonistas de receptores PPAR- $\gamma$ (Peroxisome proliferator-activated receptor gamma, PPAR-gamma). Nos 
experimentos in vitro com culturas primárias de micróglia estimuladas com LPS, os autores observaram que há aumento da expressão de Iba-1 - sugerindo ativação microglial. O CBD preveniu o efeito do LPS, através de receptores PPAR- $\gamma$ (SONEGO; PRADO; VALE; SEPULVEDA-DIAZ et al., 2018). Por fim, resultados de trabalhos não publicados do nosso grupo, evidenciaram que o CBD induz processos autofágicos a nível central; um importante mecanismo de inibição da ativação de micróglias e da plataforma de NLRP3.

Recentemente, Liu e colaboradores verificaram que os efeitos anti-inflamatórios do CBD podem estar associados com a regulação da ativação do inflamassoma de NLRP3 em um modelo de esteatose não-alcoólico em camundongos. Além disso, o CBD diminuiu a ativação dessa plataforma em monócitos THP-1 ativados com nigericina e/ou LPS e, por estudos computacionais, observou-se que esse efeito envolve a modulação do receptor P2X7 (LIU; MA; SLITT; SEERAM, 2020).

Trata-se, portanto, de uma área pouco explorada mas de grande importância, dadas as evidências brevemente resumidas acima do envolvimento destas alterações não apenas em psicoses mas em diversos outros transtornos neuropsiquiátricos nos quais o CBD têm potencial terapêutico (LISBOA; GOMES; GUIMARAES; CAMPOS, 2016). 
Hipótese 


\section{HIPÓTESE}

Considerando a co-localização dos marcadores de micróglias e do receptor NLRP3 no SNC de roedores expostos a protocolos estresse crônico, as evidências previamente descritas de que tanto este receptor quanto as micróglias estão associadas às consequências comportamentais de estresse, e que o CBD possui efeitos comportamentais e anti-inflamatórios; a hipótese original do projeto foi a de que a via do inflamassoma de NLRP3, em células da micróglia, está envolvida nos mecanismos pelos quais a administração do CBD preveniria as consequências comportamentais e neuroimunoendócrinas dos modelos de transtornos psiquiátricos utilizados. 
$\underline{\text { Objetivos }}$ 


\section{OBJETIVOS}

\section{Originais - Primeira parte do projeto (Brasil)}

\subsection{Objetivo geral}

Avaliar o efeito do $\mathrm{CBD}$ sobre as consequências comportamentais e neuroimunoendócrinas do estresse em comportamentos relacionados à depressão e ansiedade.

\subsection{Objetivos específicos}

- Verificar se os tratamentos, repetido ou agudo, com o Canabidiol previnem alterações comportamentais associadas a fenótipos tipo-depressivos e tipo-ansiosos.

- Avaliar se os protocolos de estresse alteram os níveis de corticosterona plasmática nos animais, bem como avaliar os efeitos do tratamento repetido com o CBD sobre tais níveis.

- Avaliar se os efeitos comportamentais induzidos pelo estresse são acompanhados por aumento nos níveis de citocinas pró-inflamatórias (IL-1 $\beta$, TNF e IL-6) e diminuição de citocinas anti-inflamatórias (IL-10) no soro e em duas regiões associadas à depressão, o hipocampo (HIP) e no córtex pré-frontal (CPF). Avaliar os efeitos do CBD sobre tais respostas.

- Avaliar se há aumento da expressão gênica e/ou proteica de pró-IL-1 $\beta$, IL-1 $\beta$, NLRP3, ASC e Caspase-1 ativa no HIP e CPF dos animais (estressados ou não) e se este efeito é inibido pelo CBD.

- Verificar se o estresse altera a expressão gênica de IL-1 $\beta$, NLRP3, Caspase-1 ativa e ASC em células $\mathrm{CD} 11 \mathrm{~b}^{+} \mathrm{CD} 45^{\text {low }}$ (micróglias) isoladas do cérebro de animais (não estressados e estressados) e se este efeito é prevenido pelo CBD.

- Avaliar os efeitos do CBD sobre a produção de citocinas, expressão gênica de IL-1 $\beta$, NLRP3, Caspase-1 e ASC em cultura de células $\mathrm{CD} 11 \mathrm{~b}^{+} \mathrm{CD} 45^{\text {low }}$ isoladas a partir do cérebro de 
animais naive adultos e ativadas ex vivo por LPS + ATP. Comparar os resultados dos experimentos in vivo com os obtidos in vitro.

- Avaliar se o estresse aumenta a ativação de micróglias no CPF e HIP, através da colocalização entre Iba-1 e DAPI ou Iba-1, NLRP3 e IL-1 $\beta$ nessas regiões e os efeitos do CBD sobre estas alterações.

\section{Secundários - Segunda parte do projeto (Alemanha)}

\subsection{Objetivo geral}

Avaliar o efeito do tratamento com o CBD sobre parâmetros comportamentais e neuroimunoendócrinos em dois modelos animais de transtornos mentais - ansiedade psicopatológica baseado no acasalamento seletivo ou PTSD.

\subsection{Objetivos específicos}

- Verificar se o tratamento agudo com o Canabidiol melhora as alterações comportamentais associadas a fenótipos relacionados à ansiedade em um modelo psicopatológico de ansiedade baseado em acasalamento seletivo.

- Verificar se o tratamento repetido com o Canabidiol reverte as alterações comportamentais induzidas por um modelo animal de PTSD baseado em choques nas patas.

- Avaliar os níveis de corticosterona plasmática nos animais de ambos os modelos, bem como avaliar os efeitos do tratamento com o CBD sobre tais níveis.

- Avaliar se os efeitos comportamentais provenientes do acasalamento seletivo ou trauma são acompanhados por aumento nos níveis de citocinas pró-inflamatórias (IL-1 $\beta$, TNF e IL-6) e diminuição de citocinas anti-inflamatórias (IL-10) no soro e em duas regiões associadas à transtornos mentais, o hipocampo (HIP) e no córtex pré-frontal (CPF). Avaliar os efeitos do CBD sobre tais respostas. 
- Avaliar se há aumento da expressão gênica e/ou proteica de pró-IL-1 $\beta$, IL-1 $\beta$, NLRP3, ASC e Caspase-1 ativa no HIP e CPF dos animais e se este efeito é inibido pelo CBD.

- Avaliar os efeitos do CBD sobre a produção de citocinas, expressão gênica de IL-1 $\beta$, NLRP3, Caspase-1 e ASC em cultura primária de micróglias e ativadas ex vivo por LPS. Comparar os resultados dos experimentos in vivo com os obtidos in vitro. 
Material e Métodos 


\section{MATERIAL E MÉTODOS}

\subsection{Experimentos realizados no Brasil}

\subsubsection{Animais}

Camundongos C57BL/6 (5-6 semanas de idade) provenientes do Biotério Central da USP-Ribeirão Preto foram alocados em grupos de 8-10 animais por gaiola e aclimatados no biotério do departamento de Farmacologia da FMRP-USP por 1-2 semanas para chegarem à idade necessária para o início dos experimentos (animais adultos; 7-8 semanas). Os animais foram mantidos com água e comida ad libitum, sob ciclo claro-escuro de $12 \mathrm{~h}$ e temperatura controlada $\left(24 \pm 1^{\circ} \mathrm{C}\right)$.

Todos os procedimentos experimentais utilizados no presente trabalho estiveram em concordância com o guia de uso e cuidados de animais de laboratório da Sociedade Brasileira de Neurociência e Comportamento. As condições de habitação e protocolos foram previamente aprovadas pelo Comissão de Ética no Uso de Animais do Campus da USP de Ribeirão Preto (CEUA, número do processo: 132/2016).

\subsubsection{Drogas e Tratamento}

Canabidiol (CBD; 30 mg/kg; BSPG, UK) dissolvido em 2\% Tween80 em salina. A dose do CBD foi baseada naquela que apresentou efeitos tipo-antidepressivo e tipo-ansiolítico em estudos do nosso grupo após administração aguda ou repetida por 14 dias (CAMPOS; FERREIRA; GUIMARAES, 2012; CAMPOS; ORTEGA; PALAZUELOS; FOGACA et al., 2013; HARTMANN; LISBOA; SONEGO; COUTINHO et al., 2019; ZANELATI; BIOJONE; MOREIRA; GUIMARAES et al., 2010).

Fluoxetina (FLX; 10 mg/kg; EMS, BR) dissolvido em salina. A dose de FLX foi baseada em trabalhos prévios da literatura (Du et al., 2016).

Veículo (VEI), assim com as drogas, foram administrados no volume final de $10 \mathrm{ml} / \mathrm{kg}$. 
Nos experimentos utilizando o modelo do CUS, a injeção intraperitoneal (i.p.) foi realizada 2 a 3 h após o término do estresse. Durante os estressores longos (ciclo claro ou escuro), os animais foram administrados entre as 14 e $15 \mathrm{~h}$, independentemente de estarem submetidos aos estressores.

Nos experimentos utilizando o modelo de estresse único por restrição e tratamento agudo, a administração do CBD ou VEI aconteceu 2 a 3 h após o término do estresse e, nos dias subsequentes, as injeções eram apenas de VEI. No protocolo de tratamento repetido, os animais receberam a primeira injeção de CBD ou VEI, 2 a 3 h após o término do estresse e, nos dias subsequentes, a administração ocorreu na mesma faixa de horário do primeiro dia.

Em todos os casos, a única ou última injeção de CBD ocorreu aproximadamente $20 \mathrm{~h}$ antes do teste comportamental.

\subsubsection{Modelos Animais}

\subsubsection{Estresse Crônico Imprevisivel (CUS, "Chronic Unpredictable Stress")}

Sete dias antes do início do protocolo de estresse, os camundongos foram pesados e alocados individualmente ou agrupadamente em caixas (5 animais/caixa), dependendo do protocolo. A avaliação do peso corporal foi realizada no dia do início do protocolo e a cada 7 dias durante a realização do mesmo. Os animais foram submetidos a uma sequência de estressores imprevisíveis e randomizados por um período de 21 dias (Fig. 1) (WILLNER; MUSCAT; PAPP, 1992). Os estressores utilizados foram: exposição - visual e olfativa - ao potencial predador (rato) e à sua maravalha (8 min), choque elétrico nas patas (1 único choque - $1 \mathrm{~mA}, 2 \mathrm{~s})$, restrição $(2 \mathrm{~h})$, maravalha molhada durante $18 \mathrm{~h}$, ciclo claro (24h), ciclo escuro (24h), iluminação intermitente (luzes ligadas e apagadas a cada $2 \mathrm{~h}$ durante $18 \mathrm{~h}$ ). As exposições de curta duração foram realizadas entre as 10 e $12 \mathrm{~h}$ do período matutino; já as de longa duração, tiveram início as $18 \mathrm{~h}$ e encerraram as $12 \mathrm{~h}$ (exceto o ciclo claro e escuro, que duraram $24 \mathrm{~h}$ ). Variações no protocolo serão discutidas 
na sessão Delineamento Experimental.

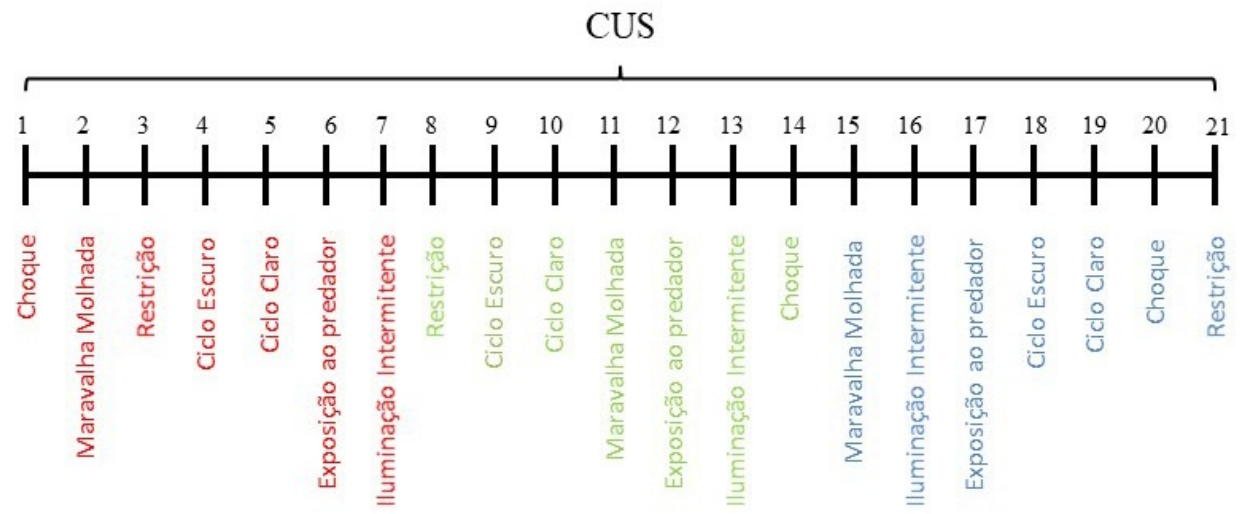

Fig. 1 - Cronograma de agentes estressores utilizados no protocolo de estresse crônico imprevisível.

\subsubsection{Estresse único por restrição}

Sete dias antes do dia de estresse, os camundongos foram agrupados em caixas (4 animais/caixa). Na manhã do dia de estresse, os camundongos foram direcionados para a sala de experimentação, onde permaneceram por aproximadamente 30 minutos para habituação. Posteriormente, foram colocados em tubos falcon $(50 \mathrm{ml})$ devidamente perfurados (permitindo a respiração do animal) por 6 horas. Após a retirada dos animais dos tubos, eles foram mantidos em pares até a manhã do dia seguinte ou por uma semana, dependendo do protocolo.

\subsubsection{Testes Comportamentais}

4.1.4.1. Teste de preferência pela sacarose (SPT, "Sucrose preference test")

O teste foi empregado para avaliar a redução da responsividade a estímulos prazerosos, conhecido como anedonia. Para isso, a preferência pela sacarose dos animais foi realizada antes (basal) e após o protocolo de estresse. Os animais foram habituados ao consumo de solução de sacarose - uma garrafa contendo água e outra contendo a solução de sacarose (concentração variável, 1 ou $2 \%$ ) estiveram disponíveis, sendo que a posição foi invertida para evitar preferência 
por um dos lados ou pelo ciclo. Após este período de habituação, os animais permaneceram sem água por 8-9 h e, então, as garrafas contendo água ou solução de sacarose foram novamente colocadas nas gaiolas por um período de $14 \mathrm{~h}$ (a posição das garrafas foi invertida após $7 \mathrm{~h}$ ). $\mathrm{O}$ consumo foi medido através do peso das garrafas antes e após o teste e a porcentagem de preferência por sacarose (\% PS) calculada de acordo com a fórmula: [solução de sacarose consumida / (solução de sacarose consumida + água consumida) $* 100$. Neste teste, modelos baseados em estresse tendem a diminuir a preferência pela sacarose, enquanto drogas com propriedades antidepressivas tendem a restaurá-la. Variações no protocolo serão discutidas na sessão Delineamento experimental.

\subsubsection{Teste do labirinto em cruz elevado (LCE)}

Os animais foram expostos ao teste do LCE para verificar a ocorrência de efeito tipoansiogênico no grupo previamente exposto ao estresse. O aparato de madeira é constituído por dois braços abertos opostos sem paredes laterais $(30 \times 5 \times 15 \mathrm{~cm})$ perpendiculares a dois braços fechados (30 x $5 \times 15 \mathrm{~cm})$, apresentando uma plataforma central comum a todos os braços $(5 \mathrm{x}$ $5 \mathrm{~cm})$. Além disso, é elevado $50 \mathrm{~cm}$ do solo e possui uma borda de acrílico $(1 \mathrm{~cm})$ nos braços abertos para dificultar a queda do animal. O comportamento teve duração de 5 minutos e foi registrado através de uma vídeo-câmera e analisado pelo programa ANY-Maze ${ }^{\circledR}$ para detectar a posição do animal e calcular automaticamente o número de entradas nos braços fechados, utilizado como medida de atividade locomotora, e as porcentagens de entrada e tempo nos braços abertos (parâmetros relacionados à ansiedade). Ao final de cada teste, o aparato era limpo com álcool $70 \%$. Neste teste, o regime do CUS tende a reduzir a frequência e o tempo de permanência nos braços abertos do LCE, enquanto drogas com propriedades ansiolíticas tendem a aumentálos.

\subsubsection{Teste do nado forçado (FST, "Forced swim test”)}

O teste de nado forçado foi utilizado para a avaliação de comportamentos tipo- 
depressivos induzidos pelo estresse. Os camundongos foram colocados individualmente em cilindros de vidro $(17 \times 25 \mathrm{~cm})$ contendo água $\left(10 \mathrm{~cm}, 23-25^{\circ} \mathrm{C}\right)$ para avaliação de comportamentos tipo-depressivos. Os animais permaneceram no cilindro por 6 min, sendo que nos 4 últimos min foi registrado o tempo em que permanecerem imóveis (realizando apenas pequenos movimentos para auxiliar na flutuação). A água foi trocada a cada animal. Todos os testes foram gravados e o tempo de imobilidade avaliado. Neste teste, o regime do CUS tende a aumentar o tempo de imobilidade dos animais, enquanto drogas com propriedades antidepressivas tendem a diminuí-lo.

\subsubsection{Teste de supressão da alimentação pela novidade (NSF, "Novelty supressed fedding”)}

O teste de supressão da alimentação pela novidade foi utilizado para a avaliação de comportamentos relacionados à ansiedade induzidos pelo estresse. Os camundongos foram privados de comida por $24 \mathrm{~h}$ e colocados por 5 min em uma caixa transparente ( 40 × 40 x $30 \mathrm{~cm}$ ) contendo aproximadamente $2 \mathrm{~cm}$ de serragem cobrindo o solo; e uma plataforma central contendo um único pellet de ração e iluminação focada apenas nesta plataforma. A latência para que o animal se posicionasse no centro da caixa e comesse a ração, por no mínimo 5 segundos, foi medida. Para descartar a hipótese de que a droga altera o consumo de comida, após o teste os animais foram reposicionados em suas caixas de permanência e a quantidade de comida consumida em 5 minutos foi pesada. Neste modelo, o regime do CUS tende a aumentar a latência para os animais iniciarem o consumo de comida na caixa, enquanto drogas com propriedades ansiolíticas tendem a diminuí-la.

\subsubsection{Teste de campo aberto (OFT, “Open field test”)}

Os animais foram expostos ao OFT para avaliar os efeitos do estresse sobre a atividade locomotora dos animais. Os animais foram colocados na periferia do campo aberto e puderam explorar o aparato durante $5 \min (40 \times 40 \times 40 \mathrm{~cm})$. O comportamento do animal foi registrado 
através de uma vídeo-câmera e analisado pelo programa ANY-Maze ${ }^{\circledR}$ para detectar a posição do mesmo e, a partir disso, calcular automaticamente a distância total percorrida.

\subsubsection{Teste de suspensão pela cauda (TST, "Tail suspension test”)}

Assim como no FST, o teste de suspensão pela cauda foi utilizado para a avaliação de respostas de enfrentamento frente à exposição a um desafio comportamental agudo, ou seja, para avaliar respostas de stress coping e comportamentos tipo-depressivos induzidos pelo estresse. Para isso, os animais foram suspensos pela cauda a $50 \mathrm{~cm}$ do chão por 6 minutos e, durante esse período, foi avaliado o tempo de imobilidade. No caso de queda do animal, houve tolerância de $1 \mathrm{vez}$; enquanto 3 tentativas foram dadas em episódios de escalada de cauda. Todos os testes foram gravados e o comportamento posteriormente avaliado. Neste teste, o estresse tende a aumentar o tempo de imobilidade dos animais, enquanto drogas com propriedades antidepressivas tendem a diminuí-lo.

\subsubsection{Medo condicionado ao contexto (MCC)}

Os animais foram habituados em uma caixa de condicionamento $(23 \times 20 \times 21 \mathrm{~cm})$ durante 2 min e, após esse tempo, receberam 3 choques elétricos randomizados $(0,75 \mathrm{~mA}, 2 \mathrm{~s})$ nas patas. Após o término dos choques, permaneceram na caixa por mais 2 min para associação entre o contexto e os choques recebidos neste contexto. No dia seguinte, os animais foram colocados na mesma caixa por $5 \mathrm{~min}$, sem deflagração de choques, para avaliar o a resposta de medo condicionada (RMC), representada pelo aumento no tempo de congelamento.

\subsubsection{Análises Moleculares}

\subsubsection{Eutanásia e coleta de órgãos para análises moleculares}

Imediatamente após o último teste comportamental, os animais foram anestesiados com uretana $25 \%$ e o sangue coletado por exoftalmia em tubos plásticos. O soro foi obtido a partir da centrifugação do sangue (1500-2000 rpm, $\left.20 \mathrm{~min}, 4^{\circ} \mathrm{C}\right)$. Após a coleta de sangue, os animais 
foram laparatomizados para obtenção de um fragmento do baço e, então, decapitados para coleta do encéfalo e dissecação das regiões do Córtex pré-frontal ventromedial (CPF), Estriado (EST) e Hipocampo (HIP). Todas as amostras biológicas foram imediatamente congeladas em gelo seco e armazenadas a $-70^{\circ} \mathrm{C}$. O Estriado foi coletado para ser usado como região controle.

\subsubsection{Dosagem de citocinas (ELISA)}

A quantificação de citocinas foi feita a partir do soro e do cérebro dos animais. As regiões cerebrais previamente congeladas foram imersas em tampão fosfato (PBS) contendo inibidor de protease $4 \%(\mathrm{v} / \mathrm{v}, 150 \mu \mathrm{L}$ para HIP e EST, $100 \mu \mathrm{L}$ para CPF; Sigma-Aldrich, MO, USA) e imediatamente homogeneizadas. As amostras foram submetidas ao método de ELISA para detecção das concentrações de IL-1 $\beta$, seguindo as instruções do fabricante (R\&D System, MN, USA). Os valores foram corrigidos pela quantidade de proteína total do tecido, obtida pelo método de Bradford.

\subsubsection{3. $\quad$ Análise de expressão gênica por PCR em tempo real (qRT-PCR)}

As amostras cerebrais congeladas e processadas em Trizol (Life Technologies, USA) e o RNA das estruturas cerebrais foi isolado através do protocolo com clorofórmio e álcool isopropílico. O RNA extraído foi submetido à confecção do DNA complementar (cDNA) (High Capacity, Life Technologies, USA), de acordo com as especificações do fabricante. A análise relativa de transcritos dos genes alvo (NLRP3 - Nlrp3, ASC - Pycard, Caspase-1 - Casp-1, IL-1 $\beta$ - Il-1b) foi realizada por PCR em tempo real, utilizando o cDNA confeccionado, através do sistema TaqMan. Os valores de Ct (cicle threshold ou linha de corte) de cada gene de interesse foram normalizados pela média do $\mathrm{Ct}$ dos controles endógenos (genes Gapdh ou $\beta$-actina, constitutivamente expressos). As alterações nos níveis de RNAm na amostra de interesse em relação ao grupo controle foram determinadas pelo método do $2^{-\Delta \Delta \mathrm{Ct}}$, sendo $\Delta \Delta \mathrm{Ct}=\Delta \mathrm{Ct}$ amostra interesse $-\Delta c t$ grupo controle. 


\subsubsection{Delineamento experimental}

\subsubsection{Padronização do modelo de estresse crônico imprevisível por 21} dias

Nosso grupo havia verificado previamente que o modelo do CUS por 14 dias induz alterações comportamentais tipo-ansiogênicas em camundongos C57BL/6 prevenidas pela administração repetida de CBD (30 mg/kg). Além disso, os estudos demonstraram a participação da neurogênese hipocampal nos efeitos deste fitocanabinóide (CAMPOS; ORTEGA; PALAZUELOS; FOGACA et al., 2013; FOGACA; CAMPOS; COELHO; DUMAN et al., 2018). Entretanto, trabalhos que visam avaliar a participação de componentes do sistema imunológico mediando efeitos anti-estresse de drogas, frequentemente utilizam protocolos de CUS com maior duração. Considerando que a principal hipótese a ser testada no presente projeto era a de que a via do inflamassoma de NLRP3, em células da micróglia no cérebro, estaria envolvida nos mecanismos pelos quais a administração do CBD preveniria as consequências comportamentais e neuroimunoendócrinas do CUS, propusemos um novo protocolo de estresse. Para isso, aumentamos a intensidade de alguns estressores e o tempo de duração do protocolo para 21 dias, de modo a permitir a maior ativação dos sistemas potencialmente envolvidos nas alterações comportamentais induzidas pelo estresse.

\subsection{Experimento 1:}

Durante o primeiro experimento realizado, seguimos o protocolo de estresse previamente descrito na sessão 4.1.3.1., de modo que os animais foram mantidos isolados e aleatoriamente divididos em grupos estressado e não estressado ( $n=8 /$ grupo). Ambos os grupos receberam injeções diárias de salina, de modo a evitar possíveis alterações posteriores nos valores basais de comportamento em decorrência das administrações diárias. O organograma experimental pode ser visto na Fig. 2. As habituações à solução de sacarose tiveram início $3^{\circ}$ e $25^{\circ}$ dias do protocolo e duraram $48 \mathrm{~h}$; a posição das garrafas foi invertida após $24 \mathrm{~h}$. Tanto a privação de líquidos quanto o teste de preferência pela sacarose, tiveram duração de $14 \mathrm{~h} /$ cada. $\mathrm{O}$ teste de preferência pela 
sacarose $(1 \%)$ foi realizado das $17 \mathrm{~h}$ às $7 \mathrm{~h}$ do dia anterior ao início do estresse $\left(5^{\circ}-6^{\circ}\right.$ dia do protocolo) e durante a noite seguinte ao último estressor (27-28 dia de protocolo experimental). A posição das garrafas foi invertida as 00:00, ou seja, na metade do tempo total de teste. Na manhã seguinte ao último dia de estresse ( $28^{\circ}$ dia do protocolo), os animais foram testados no LCE e, imediatamente após, no FST. Logo após a realização destes testes, os animais foram privados de comida por $24 \mathrm{~h}$ para a realização do NSF, no $29^{\circ}$ dia de protocolo experimental.

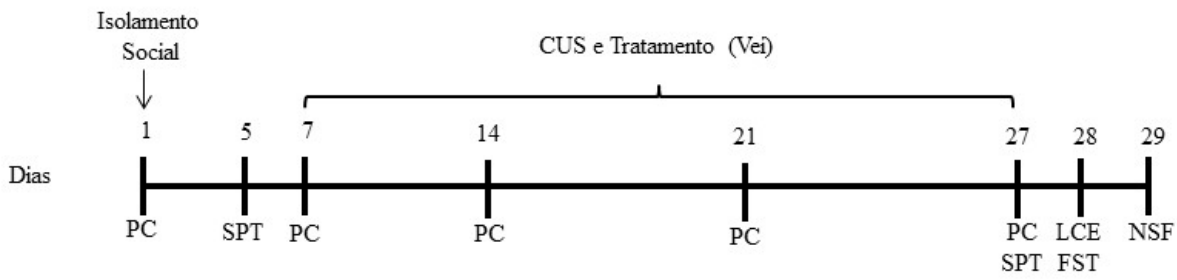

Fig. 2 - Protocolo experimental utilizado no experimento 1. PC: Peso corpóreo. SPT: Teste de preferência pela sacarose. LCE: Teste do labirinto em cruz elevado. FST: Teste de nado forçado. NSF: Teste de supressão da alimentação pela novidade. CUS: Estresse crônico imprevisível.

A partir dos resultados obtidos no teste do LCE com animais estressados, chegamos à conclusão que os animais estressados estavam apresentando sensibilidade aumentada aos braços abertos do LCE, ou seja, o estresse estava induzindo um efeito tipo-ansiolítico, uma vez que os animais adentravam nos braços abertos e apresentavam reações de congelamento ou fuga. Por isso, tivemos aumento no tempo de permanência desses animais nos braços abertos e, consequentemente, um efeito falso-positivo para atividade tipo-ansiolítica do estresse. Diante disso, concluímos que este não seria um bom teste para avaliarmos o comportamento dos animais neste modelo de estresse e o substituímos pelo OFT. Portanto, essa foi uma das alterações realizadas nos experimentos subsequentes. 


\subsection{Experimento 2:}

Ainda no sentido de ajustes experimentais, neste experimento alteramos o protocolo de preferência pela sacarose - tanto a concentração da solução quanto o tempo de habituação e teste ( $\mathrm{n}=8 /$ grupo). Os animais foram habituados com solução de sacarose 2\% por $10 \mathrm{~h}$ (08 as $18 \mathrm{~h})$, sendo que a posição das garrafas foi invertida após 5h do início da habituação. Os animais ficaram privados de água por $14 \mathrm{~h}(18 \mathrm{~h}-8 \mathrm{~h}$ do dia subsequente). O teste de preferência teve início às $8 \mathrm{~h}$ e foi conduzido de modo semelhante à habituação (10h, garrafas invertidas a cada 5h). Nesse protocolo, o tratamento e os testes comportamentais foram feitos de modo semelhante experimento anterior - com exceção do LCE que foi substituído pela arena, conforme explicado anteriormente. $\mathrm{O}$ organograma experimental pode ser visto na Fig. 3.

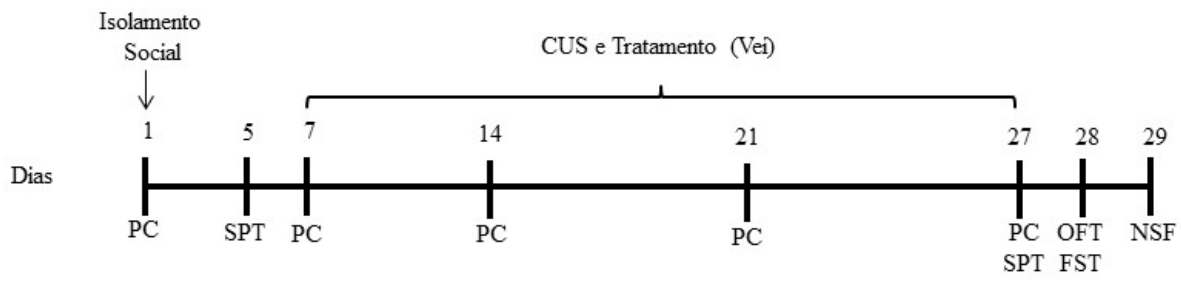

Fig. 3 - Protocolo experimental utilizado no experimento 2. PC: Peso corpóreo. SPT: Teste de preferência pela sacarose. OFT: Teste de campo aberto. FST: Teste de nado forçado. NSF: Teste de supressão da alimentação pela novidade. CUS: Estresse crônico imprevisível.

\subsection{Experimento 3:}

Com o intuito de reproduzir as alterações comportamentais induzidas pelo CUS no PC e OFT, o experimento anterior foi repetido. Entretanto, o protocolo de SPT foi alterado, aumentando o tempo de habituação e de teste, permitindo um maior período de exposição às soluções e, talvez assim, facilitando o aparecimento da diferença entre os grupos. O novo protocolo consistiu na habituação dos animais com solução de sacarose $2 \%$ por $48 \mathrm{~h}$, a posição das garrafas foi invertida após $24 \mathrm{~h}$. No dia do teste, os animais foram privados de água por $8 \mathrm{~h}$ (08 - 16h) e então receberam as garrafas contendo solução de sacarose ou água, as quais 
permaneceram nas caixas por $16 \mathrm{~h}(16 \mathrm{~h}-08 \mathrm{~h}$ do dia subsequente). A inversão de lado das garrafas foi realizada às $24 \mathrm{~h}$, ou seja, após $8 \mathrm{~h}$ de teste.

\subsection{Experimento 4:}

A partir do experimento anterior, observamos uma variabilidade considerável nas respostas comportamentais induzidas pelo protocolo de CUS. Então, considerando a possibilidade de interferência de um teste em outro devido à proximidade na execução dos mesmos e a baixa reprodutibilidade dos dados obtidos no teste do NSF; optamos por descontinuar o uso do mesmo. O novo organograma experimental pode ser visto na Fig. 4. Portanto, a partir do $4^{\mathrm{o}}$ experimento, os animais foram submetidos apenas aos testes de SPT, OFT e FST - o intervalo entre os dois últimos testes foi de $24 \mathrm{~h}$. O protocolo de preferência pela sacarose utilizado foi o mesmo do experimento anterior, entretanto decidimos testar os animais semanalmente, ao invés de apenas no início e no término do protocolo. Para isso, os animais foram habituados apenas $1 \mathrm{vez}$, antes da preferência pela sacarose basal e, posteriormente, foram submetidos apenas aos testes comportamentais.

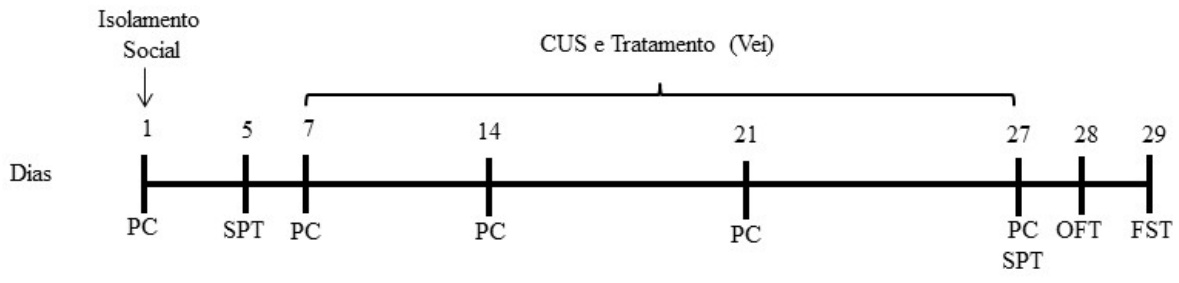

Fig. 4 - Protocolo experimental utilizado no experimento 4. PC: Peso corpóreo. SPT: Teste de preferência pela sacarose. OFT: Teste de campo aberto. FST: Teste de nado forçado. CUS: Estresse crônico imprevisível.

Apesar de termos obtido resultados semelhantes em relação ao OFT e FST nos experimentos 3 e 4 , os testes foram feitos em tempos diferentes. No $3^{\circ}$ experimento, o FST foi realizado logo após o OFT - já que no outro dia o NSF foi executado. Já no $4^{\circ}$ experimento, os animais passaram pela arena em um dia e pelo nado em outro. Portanto, como optamos por não 
mais utilizar o teste do NSF, decidimos realizar um novo experimento seguindo o presente protocolo.

\subsection{Experimento 5:}

Conforme explicado anteriormente, o presente experimento foi realizado em conformidade com o protocolo do $4^{\mathrm{o}}$ experimento. A exceção foi o protocolo do SPT, que transcorreu de modo semelhante ao $3^{\circ}$ (tempos pré e pós-estresse, apenas) - habituação dos animais à solução de sacarose $2 \%$ por $48 \mathrm{~h}$, a posição das garrafas foi invertida após $24 \mathrm{~h}$; privação de água por $8 \mathrm{~h}$ e o teste teve duração de $16 \mathrm{~h}$ (posição das garrafas invertida com $8 \mathrm{~h}$ de teste).

4.1.6.2. Expressão relativa de genes relacionados à plataforma do inflamassoma de NLRP3 e dosagens séricas e estrutura-especificas de IL-1 $\beta$ para padronização das alterações moleculares induzidas pelo CUS

\subsection{Experimento 6:}

Para a presente avaliação, utilizamos amostras de animais testados nos experimentos $3 \mathrm{e}$ 4; apesar da diferença entre os protocolos, uma vez que não houve reprodutibilidade dos dados entre o $4^{\circ}$ e $5^{\circ}$ experimentos. A partir disso, dividimos aleatoriamente as amostras dos animais para análise de expressão gênica ou dosagem de citocinas.

4.1.6.3. Avaliação dos efeitos do Canabidiol sobre as alterações comportamentais induzidas pelo estresse crônico imprevisível

Neste conjunto de experimentos, além da continuidade na padronização do CUS, decidimos começar a investigar os efeitos do CBD. Para isso, avaliamos o peso corporal dos animais semanalmente, preferência pela sacarose basal e após o estresse, além de testar os animais no campo aberto e nado forçado - com intervalo de $24 \mathrm{~h}$ entre ambos. Durante o planejamento experimental, observamos que a última injeção de CBD aconteceria entre as $14-15 \mathrm{~h}$ do $21^{\circ}$ dia de estresse e que o teste de preferência pela sacarose seria realizado com o composto presente na 
circulação. Além disso, a arena seria realizada na manhã do dia seguinte - aproximadamente $20 \mathrm{~h}$ após a última injeção, não nos permitindo diferenciar um possível efeito agudo do efeito repetido. Apesar de haverem evidências científicas farmacocinéticas de que o intervalo de 20 horas entre a última administração i.p. da droga e o teste comportamental é suficiente para garantir a eliminação quase que total do composto do organismo do animal (DEIANA; WATANABE; YAMASAKI; AMADA et al., 2012), optamos por dar um dia de intervalo entre o término do protocolo de estresse e das injeções para a realização do primeiro teste comportamental. Desse modo, todos os testes foram realizados na ausência de CBD circulante, permitindo-nos inferir que quaisquer efeitos observados seriam em decorrência do tratamento repetido e não agudo.

\subsection{Experimento 7:}

O presente experimento foi realizado seguindo os protocolos de estresse e tratamento previamente descritos, ainda com animais isolados e aleatoriamente divididos entre os grupos: não estressado - VEI, não estressado - CBD, estressado - VEI, estressado - CBD ( $n=$ 4/grupo). Ambos os tratamentos, VEI ou CBD (30 mg/kg), foram administrados diariamente, $2-3 \mathrm{~h}$ após o término do estresse. O organograma experimental completo pode ser visualizado abaixo (Fig. 5)

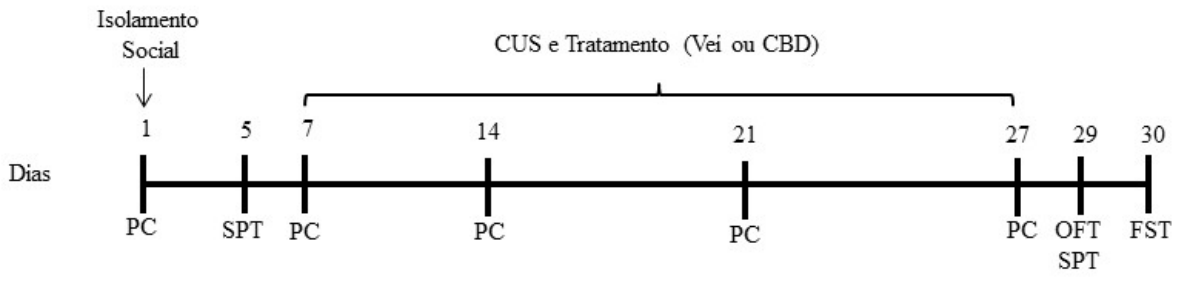

Fig. 5 - Protocolo experimental utilizado no experimento 7. PC: Peso corpóreo. SPT: Teste de preferência pela sacarose. OFT: Teste de campo aberto. FST: Teste de nado forçado. CUS: Estresse crônico imprevisível. CBD: Canabidiol.

Diante da baixa reprodutibilidade dos resultados obtidos ao longo dos experimentos e da necessidade do tratamento com o CBD e com o VEI, decidimos parar de utilizar o isolamento 
social e passar a manter os animais agrupados; conforme já havia sido realizado previamente em nosso laboratório (CAMPOS; ORTEGA; PALAZUELOS; FOGACA et al., 2013; FOGACA; CAMPOS; COELHO; DUMAN et al., 2018). Assim, conseguimos aumentar o número amostral por grupo em cada experimento. Além disso, o teste de preferência pela sacarose também foi deixado de ser utilizado, tanto pela dificuldade em obter resultados consistentes, quanto pela inviabilidade em fazer esse teste com animais agrupados - pois não haveria como distinguirmos o consumo individual.

\subsection{Experimento 8:}

Os animais foram agrupados (5/caixa) 7 dias antes do início do protocolo e aleatoriamente divididos em grupos estressado e não estressado, além de tratados ou não com CBD (n=10/grupo; Fig. 6). Todos os grupos experimentais receberam injeções diárias de salina ou canabidiol (30 $\mathrm{mg} / \mathrm{kg}$ ), de modo a evitar possíveis alterações posteriores nos valores basais de comportamento em decorrência das administrações diárias. Na manhã seguinte ao último dia de estresse $\left(28^{\circ}\right.$ dia do protocolo), os animais foram testados no teste do LCE. Após 24 h, os animais foram submetidos ao OFT e, por fim, ao teste FST. Logo após a realização deste, os animais foram anestesiados e o soro, regiões do HIP, CPFvm e EST foram coletadas.

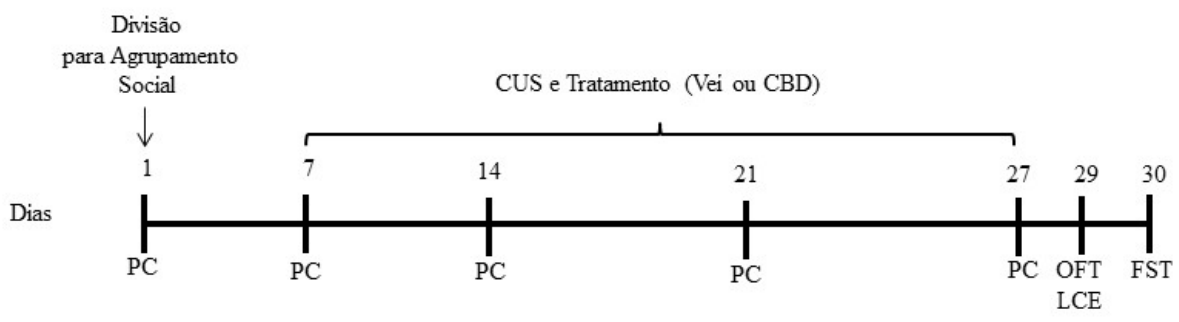

Fig. 6 - Protocolo experimental utilizado no experimento 8. PC: Peso corpóreo. LCE: Teste Do labirinto em cruz elevado. OFT: Teste de campo aberto. FST: Teste de nado forçado. CUS: Estresse crônico imprevisível. CBD: Canabidiol.

Assim como no experimento em que utilizamos o teste do LCE para avaliar os animais isolados, no presente experimento o estresse também induziu falso efeito tipo-ansiolítico. Diante 
disso, optamos por não mais utilizar o LCE em animais expostos ao CUS no presente projeto.

O experimento seguinte foi idealizado com o objetivo de avaliar a resposta dos animais ao CUS. Para isso, os animais foram submetidos a testes comportamentais antes e após o protocolo de estresse. Além disso, adicionamos a Fluoxetina como controle-positivo.

\subsection{Experimento 9:}

Neste experimento, os animais foram submetidos ao OFT em uma arena quadrada $24 \mathrm{~h}$ antes do início do CUS. Posteriormente, ao fim do protocolo, os animais foram submetidos novamente ao teste, sob as mesmas condições, em uma arena redonda para evitar uma possível habituação. Imediatamente após o OFT, foram submetidos ao FST e, então, eutanasiados. A administração de VEI, CBD (30 mg/kg) ou FLX (10 mg/kg) aconteceu diariamente, 2-3 h após o término do estresse, como explicado anteriormente. Os demais procedimentos experimentos podem ser observados na Fig. 7 .

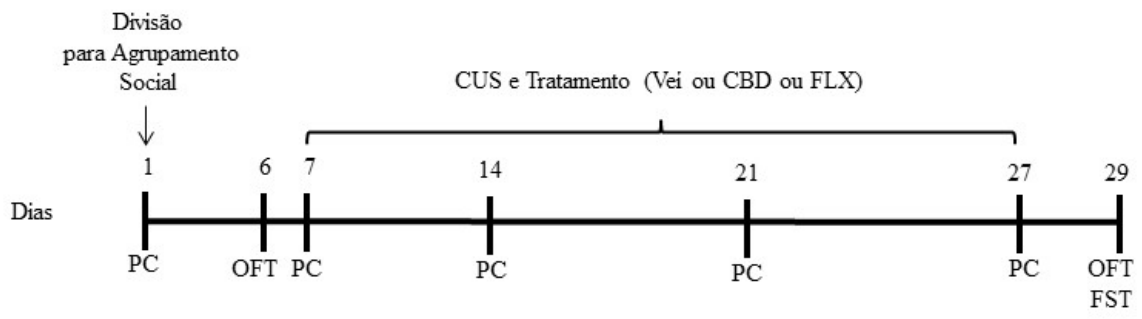

Fig. 7 - Protocolo experimental utilizado no experimento 9. PC: Peso corpóreo. OFT: Teste de campo aberto. FST: Teste de nado forçado. CUS: Estresse crônico imprevisível. CBD: Canabidiol. FLX: Fluoxetina.

O estresse não induziu as alterações previamente observadas. Diante disso, realizamos a análise exploratória dos dados, um a um, a fim de identificar um padrão de resiliência e suscetibilidade dos animais ao protocolo de estresse. Nesse sentido, observamos que animais que possuam atividade locomotora alta na avaliação basal, eram de certo modo resilientes aos 
efeitos do estresse (dados não mostrados). Entretanto, esses animais correspondiam a aproximadamente $25 \%$ de todo o número amostral - praticamente inviabilizando e comprometendo o $\mathrm{n}$ experimental, uma vez que o número de animais a serem excluídos da análise, era bastante significativo.

$\mathrm{Na}$ época, a partir das observações e resultados aqui descritos, além da dificuldade na execução de outros protocolos de estresse em nosso próprio grupo de pesquisa e em grupos de pesquisa colaboradores dentro da FMRP-USP, decidimos testar outros protocolos de estresse que induzam alterações comportamentais de longo prazo, permitindo verificar a associação entre estas alterações e parâmetros imunológicos. Para isso, utilizamos o modelo de estresse único prolongado (dados não serão mostrados) e o modelo único por restrição, conforme descrito na sessão 4.1.3.2. da sessão Material e métodos.

\subsubsection{Padronização do modelo de estresse único por restrição}

\subsection{Experimento 10:}

Inicialmente, realizamos o modelo e testamos os animais no LCE no dia seguinte ao estresse, a fim de verificar se o mesmo era capaz de induzir alterações comportamentais significativas.

Diante das alterações comportamentais, decidimos dar continuidade ao protocolo em que os animais seriam avaliados 7 dias após o estresse.

\subsection{Experimentos 11, 12 e 13:}

No presente experimento, gerado a partir de 3 experimentos independentes, utilizamos a dose de $30 \mathrm{mg} / \mathrm{kg}$ de CBD tanto no protocolo de tratamento agudo quanto repetido. Sete dias após a sessão única de estresse, os animais foram submetidos ao LCE e, imediatamente após, ao TST.

Diante dos resultados observados que serão posteriormente descritos, decidimos realizar novos experimentos com a dose de $15 \mathrm{mg} / \mathrm{kg}$ de CBD e trocar o TST pelo MCC. 


\subsection{Experimentos 14, 15 e 16:}

O experimento descrito nessa sessão, assim como o anterior, foi gerado a partir de 3 experimentos independentes. Os animais foram submetidos ao protocolo de estresse agudo e avaliados sete dias depois no teste do LCE. Ao término do teste, realizamos o protocolo do MCC, conforme descrito na sessão 4.1.4.8. Os tratamentos agudo e repetido com o CBD na dose de 15 $\mathrm{mg} / \mathrm{kg}$ também foram realizados.

Os resultados gerados a partir destes experimentos não serão apresentados na tese, haja vista que o modelo de estresse que vinha sendo utilizado e nos fornecendo dados robustos, deixou de funcionar. Justamente nessa fase do projeto, todos os demais protocolos de estresse e experimentos comportamentais também pararam de funcionar em nosso laboratório. Através do compartilhamento de experiências entre docentes e alunos, tivemos conhecimento que esse problema vinha ocorrendo em outros departamentos e unidades da USP Ribeirão Preto. Com isso, na tentativa identificar a causa do problema, fomos informados que a marca da ração fornecida aos animais no Biotério Central havia sido trocada havia cerca de 3-4 meses. Após análise da ração e dos animais, foi constatado que os mesmos estavam em quadro de déficit nutricional profundo. Esse fator, provavelmente, era a causa para a perda dos fenótipos previamente observados em nossa unidade; uma vez que, ainda no biotério central, foi observada a alteração do comportamento materno das mães para com os filhotes. Nesse momento, fomos informados de que o Biotério Central pararia o fornecimento de animais por aproximadamente 90 dias a fim de reestabelecer as colônias com animais saudáveis; evitando possíveis interferências epigenéticas deste estressor.

Diante desta situação crítica e o avançado tempo de doutorado, resolvemos continuar a investigação dos efeitos do canabidiol no estresse através de estudos a serem realizados no Instituto Max-Planck de Psiquiatria, em Munique, Alemanha, com auxílio de bolsa BEPEFAPESP. 


\subsection{Experimentos realizados na Alemanha}

\subsubsection{Animais}

Camundongos HAB e NAB (do inglês, "High-" ou "Normal-anxiety behavior"; 8-12 semanas) ou camundongos C57BL/6 (8-10 semanas; Charles River Laboratories, Sulzfeld, DE) provenientes do Biotério do Instituto Max Planck de Bioquímica foram transferidos para o Instituto Max Planck de Psiquiatria no mínimo 7 dias antes dos experimentos. Os animais foram mantidos agrupados (4-5/caixa) com água e comida ad libitum, sob ciclo claro-escuro regular de $12 \mathrm{~h}$, temperatura $\left(23 \pm 4^{\circ} \mathrm{C}\right)$ e humidade $(50 \% \pm 10 \%)$ controladas. Os testes comportamentais foram executados entre 8 e $18 \mathrm{~h}$. Todos os procedimentos experimentais foram conduzidos de acordo com a Diretiva 2010/63/EEC do Conselho da União Europeia e aprovados pelo governo local da Alta Baviera (55.2-1-54-2532.Vet_02-17-206). Todos os esforços foram executados para minimizar o sofrimento e o número de animais utilizados.

\subsubsection{Drogas e Tratamento}

Canabidiol (10, 15 e 30 mg/kg; BSPG, UK) dissolvido em 2\% Tween80 (Sigma-Aldrich, DE), 1\% DMSO (Sigma-Aldrich, DE) em salina (CAMPOS; FERREIRA; GUIMARAES, 2012; CAMPOS; ORTEGA; PALAZUELOS; FOGACA et al., 2013; HARTMANN; LISBOA; SONEGO; COUTINHO et al., 2019; ZANELATI; BIOJONE; MOREIRA; GUIMARAES et al., 2010). O veículo (VEI) e o CBD foram administrados no volume final de $10 \mathrm{ml} / \mathrm{kg}$.

Nos experimentos com animais HAB, a administração i.p. do CBD (15 e $30 \mathrm{mg} / \mathrm{kg}$ ) foi realizada 60 minutos antes de cada teste comportamental. No experimento de MCC, as injeções ocorreram 60 minutos antes de cada sessão de extinção.

No experimento utilizando modelo animal de PTSD, o tratamento diário e repetido com o CBD (10 e 30 mg/kg) ou VEI teve início após 21 dias da indução do trauma. Nos dias em que os animais seriam submetidos a testes comportamentais, as injeções ocorreram 60 min antes do 
teste. $\mathrm{O}$ tratamento teve duração de 11 dias e a última injeção aconteceu aproximadamente $24 \mathrm{~h}$ antes da eutanásia.

Para os estudos in vitro, o canabidiol (1 e $10 \mu \mathrm{M}$; BSPG, UK) foi dissolvido em 100\% DMSO nos tempos 0, 4 e $24 \mathrm{~h}$ para a cultura de células (SONEGO; PRADO; VALE; SEPULVEDA-DIAZ et al., 2018). O LPS (10 ng/ml, Escherichia coli O26:B6, Sigma-Aldrich, DE) foi dissolvido em água ultrapura (SONEGO; PRADO; VALE; SEPULVEDA-DIAZ et al., 2018).

\subsubsection{Modelos Animais}

\subsubsection{Camundongos HAB ("High-anxiety behavior")}

Os camundongos $\mathrm{HAB}$ foram originados a partir do acasalamento seletivo de animais CD1 (Crl:CD1, ICR). A seleção dos pares foi feita baseada nos altos níveis de traços de ansiedade que machos e fêmeas apresentavam no teste do LCE, caracterizado pelo baixo tempo de permanência nos braços abertos do aparato $(<15 \%)$. Os camundongos NAB foram gerados a partir do mesmo procedimento, porém foram selecionados pares que apresentavam taxas regulares de exploração dos braços abertos do LCE (25 a 40\%). O estabelecimento dessas linhagens ocorreu no Instituto Max Planck de Bioquímica, Martinsried, Alemanha; de modo que HAB foi estabelecida a partir das gerações 22-25, enquanto NAB a partir de 23-24 (KROMER; KESSLER; MILFAY; BIRG et al., 2005).

\subsubsection{Modelo animal de PTSD baseado em choques inescapáveis}

Os animais foram colocados em caixas de condicionamento cúbicas com o chão em grades metálicas que permitiam a deflagração de choques (MED Associates, St. Albans, USA). Na parte inferior, a caixa possuía uma gaveta preenchida com maravalha limpa e levemente umedecida com álcool 70\%. Após $198 \mathrm{~s}$ de habituação à caixa, os animais receberam 2 choques elétricos nas patas (1,5 mA, $2 \mathrm{~s}$ de duração) com um intervalo entre choques de 70 segundos. Após o término do protocolo, os animais permaneceram na caixa por mais $60 \mathrm{~s}$ antes de retornarem para a caixa 
moradia (KAO; ANDERZHANOVA; ASARA; WOTJAK et al., 2015; KAO; HE; HENES; ASARA et al., 2016; KAO; HE; ZANNAS; HAHN et al., 2016; SIEGMUND; WOTJAK, 2007a; b). Os animais controles foram submetidos ao mesmo procedimento, porém sem a deflagração dos choques nas patas.

\subsubsection{Testes comportamentais}

\subsubsection{Teste do labirinto em cruz elevado (LCE)}

O LCE é em um aparato de acrílico opaco cinza constituído por dois braços abertos opostos sem paredes laterais $(30 \times 5 \times 15 \mathrm{~cm})$ perpendiculares a dois braços fechados $(30 \times 5 \times 15$ $\mathrm{cm})$, apresentando uma plataforma central comum a todos os braços $(5 \times 5 \mathrm{~cm})$. O aparato é elevado $30 \mathrm{~cm}$ do solo, possui a borda de acrílico elevada $(1 \mathrm{~cm})$ nos braços abertos para dificultar a queda do animal e era envolto por 3 paredes acrílicas pretas e 1 cortina preta. A intensidade de luz usada era $40 \pm 10 \%$ lux. O teste teve duração de 30 min e os animais foram colocados com a face virada para um dos braços fechados. O comportamento do animal foi registrado através de uma vídeo-câmera e analisado pelo programa $\mathrm{ANY}-\mathrm{Maze}^{\circledR}$ para detectar a posição do mesmo e calcular automaticamente a distância total percorrida e tempo de permanência nos braços fechados, abertos e zona neutra. Além disso, foi analisada a latência para $1^{\mathrm{a}}$ entrada nos braços abertos. No final de cada teste, o LCE era limpo com água contendo detergente. Neste teste, os animais $\mathrm{HAB}$ tendem a apresentar baixo tempo de permanência, assim como maior latência para primeira entrada nos braços abertos do LCE, quando comparados aos animais NAB.

\subsubsection{Teste de mania induzida pelo besouro (BMT, "Beetle mania task")}

Os animais foram individualmente colocados na extremidade de uma arena retangular $(100 \times 15 \times 37 \mathrm{~cm})$, onde podiam explorá-la livremente por $5 \min$ (Fase 1). Imediatamente após o período de habituação, ou seja, durante a fase de teste, um robô em formato de besouro $(4,5$ x 1,5 x 1,8 cm x 7,3 g x velocidade média de $25 \mathrm{~cm} / \mathrm{s}$; Innovation First Labs Inc, Tx, USA) foi inserido na arena, à distância máxima do camundongo, para livre circulação na arena por 5 min (HEINZ; 
GENEWSKY; WOTJAK, 2017). Todo o teste foi gravado utilizando o software EthoVision (Noldus, Wageningen, NLD) para posterior análise. Durante a fase 1, foi avaliado manualmente o tempo para cruzar a arena toda e a exploração vertical do ambiente (i.e., número de rearings). Já na fase 2, o número de contatos, respostas ativas e passivas foram contabilizadas. A intensidade de luz era de $100 \pm 10 \%$ lux. O aparato era limpo com água contendo detergente e seco com papel toalha a cada teste. Neste teste, espera-se que tanto os animais HAB quanto os animais estressados apresentam aumento no número de respostas ativas (fuga, corrida, esquiva) após o contato com o besouro.

\subsubsection{Medo condicionado ao som}

Os animais foram colocados em caixas de condicionamento cúbicas com o chão em grades metálicas que permitiam a deflagração de choques (MED Associates, St. Albans, USA). Na parte inferior, a caixa possuía uma gaveta preenchida com maravalha limpa e levemente umedecida com álcool 70\%. Após $180 \mathrm{~s}$ de habituação, houve a apresentação de um tom de $20 \mathrm{~s}$ $(9 \mathrm{kHz}, 80 \mathrm{~dB})$ que co-terminava com um choque nas patas $(2 \mathrm{~s}, 1 \mathrm{~mA})$. Após $60 \mathrm{~s}$ do término do protocolo, os animais retornaram para a caixa moradia. Entre 28 e 30 dias após o condicionamento, durante 3 dias consecutivos, os animais receberam injeções i.p. de VEI ou CBD e, após 60 min, foram submetidos às sessões de extinção. Para isso, foram colocados em cilindros acrílicos transparentes contendo maravalha limpa levemente umedecida com ácido acético $1 \%$ $\left(\mathrm{CH}_{3} \mathrm{COOH}\right)$ para que, além da diferenciação visual entre os contextos, houvesse também a diferenciação olfativa. Após $180 \mathrm{~s}$ de habituação, foram apresentados 10 tons de mesma intensidade e duração do condicionamento, seguindo um intervalo entre sessões de 30 a $140 \mathrm{~s}$. Para avaliação da consolidação da extinção, sete e trinta e sete dias após a última sessão de extinção (dia 3), os animais foram colocados novamente nos cilindros plásticos transparentes, sob as mesmas condições em que ocorreram as sessões de extinção, e 4 tons, de mesma intensidade e duração prévias, foram apresentados. Todas as sessões foram gravadas e, posteriormente, o 
comportamento de congelamento, definido como a ausência de movimentos, exceto por movimentos respiratórios, foi quantificado.

\subsubsection{Expressão de medo e generalização}

Estes testes foram realizados para verificar os efeitos duradouros dos choques nas patas em animais submetidos ao protocolo de PTSD previamente descrito. Para avaliação da generalização das respostas de medo, 28 dias após o protocolo de choques, os animais foram colocados em cilindros plásticos transparentes contendo maravalha limpa e levemente umedecida com ácido acético $1 \%\left(\mathrm{CH}_{3} \mathrm{COOH}\right)$. Com isso, haviam diferenças táteis, olfativas e visuais entre os contextos. Vinte e quatro horas depois da sessão de generalização, os animais foram testados para expressão e/ou recuperação espontânea do medo, através da inserção na caixa de condicionamento cúbica, sob as mesmas condições da apresentação do choque - porém, dessa vez, não houve deflagração dos choques. Ambas as sessões duraram 3 min e foram gravadas para que posteriormente fossem avaliados os comportamentos de congelamento, rearings e stretch attend postures (SAPs).

\subsubsection{Cultura celular primária de micróglias}

A região cortical de embriões C57BL/6 (dia gestacional, DG 15-16) foram individualmente dissecadas e separadas do estriados com auxílio de lupa (Leica, DE). Os reagentes usados na cultura celular foram Thermo Fisher Scientific (USA) e Sigma-Aldrich (DE). O córtex foi dissociado em meio D-MEM/glicose (Thermo Fisher) suplementado com 10\% Soro fetal bovino (FBS; Sigma-Aldrich) e 1\% Streptomicina (Sigma-Aldrich) e o conteúdo distribuído em garrafas pré-tratadas com poli-D-lisina (Sigma-Aldrich) e mantidas a $37^{\circ} \mathrm{C}$ e $5 \% \mathrm{CO}_{2}$. O meio de cultura das placas foi trocado no dia seguinte e, posteriormente, a cada 4 dias. Após aproximadamente 8 dias de cultura, as células da glia foram isoladas através de lavagem com PBS 10\% (Thermo Fisher), seguido da adição de $1 \mathrm{ml}$ de tripsina (Thermo Fisher), re-suspensão em $29 \mathrm{ml}$ meio DMEM/glicose/10\% FBS e 1\% Streptomicina e divisão em 3 novas garrafas. Quando 
os astrócitos atingiram $100 \%$ de confluência, após 10 a 12 dias do isolamento das glias, os fracos foram manualmente agitados por 15 min no fluxo celular para desprender e isolar as micróglias. As células foram contadas e plaqueadas $\left(2 \times 10^{5} / \mathrm{ml}\right)$ em placas de culturas ( 9 poços) pré-tratadas com poli-D-lisina. No dia seguinte, o meio de cultura das placas foi trocado para remoção das células mortas. Três horas depois, as células foram estimuladas com VEI (100\% DMSO), LPS (10 ng/ml, Escherichia coli strain O26:B6, Sigma-Aldrich; dissolvido em água ultrapura) e/ou CBD (10 $\mu$ M, BSPG, UK; dissolvido em 100\% DMSO) por $24 \mathrm{~h}$. Foram feitos, ainda, os pontos 0 e $4 \mathrm{~h}$ de estimulação. As doses foram baseadas em estudos prévios do nosso grupo. A pureza da cultura de micróglia foi verificada por imunofluorescência com reagente DAPI (Thermo Fisher) e anticorpo primário anti-Iba-1 (Thermo Fisher) em microscópio (Leica, DE). As amostras foram coletadas em Trizol (Thermo Fisher) e congeladas a $-80{ }^{\circ} \mathrm{C}$ para posterior análise.

\subsubsection{Análises Moleculares}

\subsubsection{Eutanásia e coleta de órgãos}

Vinte e quatro horas após o último teste comportamental, ou seja, após a sessão de expressão de medo, camundongos C57B1/6 foram eutanasiados com isoflurano (CP Pharma, Burgdorf, DE) e rapidamente decapitados para coleta de sangue e extração cerebral. Após a coleta do cérebro, o mesmo foi mantido em gelo e as regiões do CPF, HIP e EST foram imediatamente dissecadas e mantidas em gelo seco até o término da coleta para todos os animais. Após isso, as amostras foram mantidas em freezer $-80^{\circ} \mathrm{C}$. Não houve coleta de material dos animais $\mathrm{HAB}$ e NAB.

\subsubsection{Análise de expressão gênica por PCR em tempo real (qRT-PCR)}

As amostras cerebrais ou da cultura celular foram processadas em Trizol (Thermo Scientific, USA) e o RNA das estruturas cerebrais foi isolado através de protocolo com clorofórmio e álcool isopropílico. Após a extração, houve a confecção do DNA complementar (cDNA) através do kit SuperScript IV Reverse Transcriptase Reaction (Thermo Scientific, USA), 
de acordo com as especificações do fabricante. A análise relativa de transcritos dos genes alvo (Il-1b; Il-6 e Il-10) foi realizada através do Kit SYBR Green Master Mix (Thermo Scientific, USA), SYBR green primers desenhados através da plataforma Primer-Blast (Tabela 1) e equipamento Step One real-time PCR (Applied Biosystems, USA). Os valores de Ct (cicle threshold ou linha de corte) de cada gene de interesse foram normalizados pela média do Ct dos controles endógenos (genes HPRT ou $\beta$-actina, constitutivamente expressos). As alterações nos níveis de RNAm na amostra de interesse em relação ao grupo controle foram determinadas pelo método de $\Delta \mathrm{Ct}$.

Tabela 1 - Sequência de pares de primers utilizados para qPCR

\begin{tabular}{|c|c|c|}
\hline Primers & Sequência Forward & Sequência Reverse \\
\hline IL-1 $\beta$ & 5'-GGGCCTCAAAGGAAAGAATC-3' & 5'-TACCAGTTGGGGAACTCTGC-3' \\
\hline TNF- $\alpha$ & 5'-CAGGCGGTGCCTATGTCTC-3' & 5'-CCATTTGGGAACTTCTCATCCCTT-3' \\
\hline IL-6 & 5'-ACAACCACGGCCTTCCCTA-3' & 5'-TTGCCATTGCACAACTCTTTTCTC-3' \\
\hline IL-10 & 5'-GTAGAAGTGATGCCCCAGGC-3' & 5'-AGAAATCGATGACAGCGCCTC-3' \\
\hline
\end{tabular}

\subsubsection{Delineamento experimental}

4.2.7.1. Avaliação dos efeitos do Canabidiol sobre parâmetros comportamentais e imunológicos em um modelo psicopatológico genético de ansiedade

Conforme explicado anteriormente, os camundongos $\mathrm{HAB}$ e NAB foram desenvolvidos a partir de acasalamento seletivo, objetivando aumentar a frequência de materiais genéticos relacionados à ansiedade e, consequentemente, deslocando o fenótipo da média da população NAB. Alterações comportamentais entre os animais $\mathrm{HAB}$ e NAB já foram descritas para 
inúmeros testes comportamentais - caixa claro-escuro, vocalização ultrassônica, LCE, OFT, FST, TST, step-down, teste de mania induzida pelo besouro, dentre outros (FILIOU; WEBHOFER; GORMANNS; ZHANG et al., 2012; FILIOU; ZHANG; TEPLYTSKA; RECKOW et al., 2011; HEINZ; GENEWSKY; WOTJAK, 2017; KROMER; KESSLER; MILFAY; BIRG et al., 2005; LANDGRAF; KESSLER; BUNCK; MURGATROYD et al., 2007; NUSSBAUMER; ASARA; TEPLYTSKA; MURPHY et al., 2016; YEN; ANDERZHANOVA; BUNCK; SCHULLER et al., 2013; YEN; MAUCH; DAHLHOFF; MICALE et al., 2012). Além disso, também já foi observado que camundongos HAB apresentam aumento em respostas emocionais condicionadas, generalização e recuperação espontânea do medo; processos bastantes importantes para o desenvolvimento de transtornos de ansiedade e, principalmente, para PTSD. Com relação aos mecanismos, esses animais parecem ter alterações na neurotransmissão GABAérgica amígdalar, ao nível de síntese, liberação e expressão de receptores. Ainda no sentindo mecanístico, já foi demonstrado prejuízos em processos antioxidantes por conta de alterações mitocondriais. No entanto, apesar de diversos parâmetros comportamentais, moleculares e bioquímicos já terem sido investigados em animais $\mathrm{HAB}$ e $\mathrm{NAB}$, o possível envolvimento de mecanismos imunológicos ainda não havia sido alvo de interesse.

Diante disso, decidimos avaliar se o CBD teria efeito sobre as alterações comportamentais observadas nesses animais e se haveria a participação de mecanismos inflamatórios, tanto na instalação do quadro quanto no mecanismo de ação do CBD.

\subsection{Experimento 17}

Três semanas após a chegada dos animais ao Max Planck de Psiquiatria, o grupo HAB foi aleatoriamente dividido em subgrupos que receberiam VEI, CBD $15 \mathrm{mg} / \mathrm{kg}$ ou $30 \mathrm{mg} / \mathrm{kg}$. Os animais NAB receberam apenas VEI. A administração das drogas ocorreu 60 min antes do teste do LCE ( $\mathrm{n}=8-12$ /grupo). Uma semana depois do LCE, os mesmos animais receberam uma nova injeção da mesma droga anteriormente administrada, 60 min antes do teste de mania induzida pelo besouro $(\mathrm{n}=12 /$ grupo $)$. 
Após duas semanas, os animais foram submetidos ao protocolo condicionamento ao som, conforme protocolo descrito na sessão 4.2.4.3 e apresentado na Fig. 8. A resposta frente ao choque nas patas foi classificada pelo experimentador para que, posteriormente, se fosse necessário descartar algum animal, soubéssemos como havia sido a resposta imediata ao estímulo incondicionado (choque).

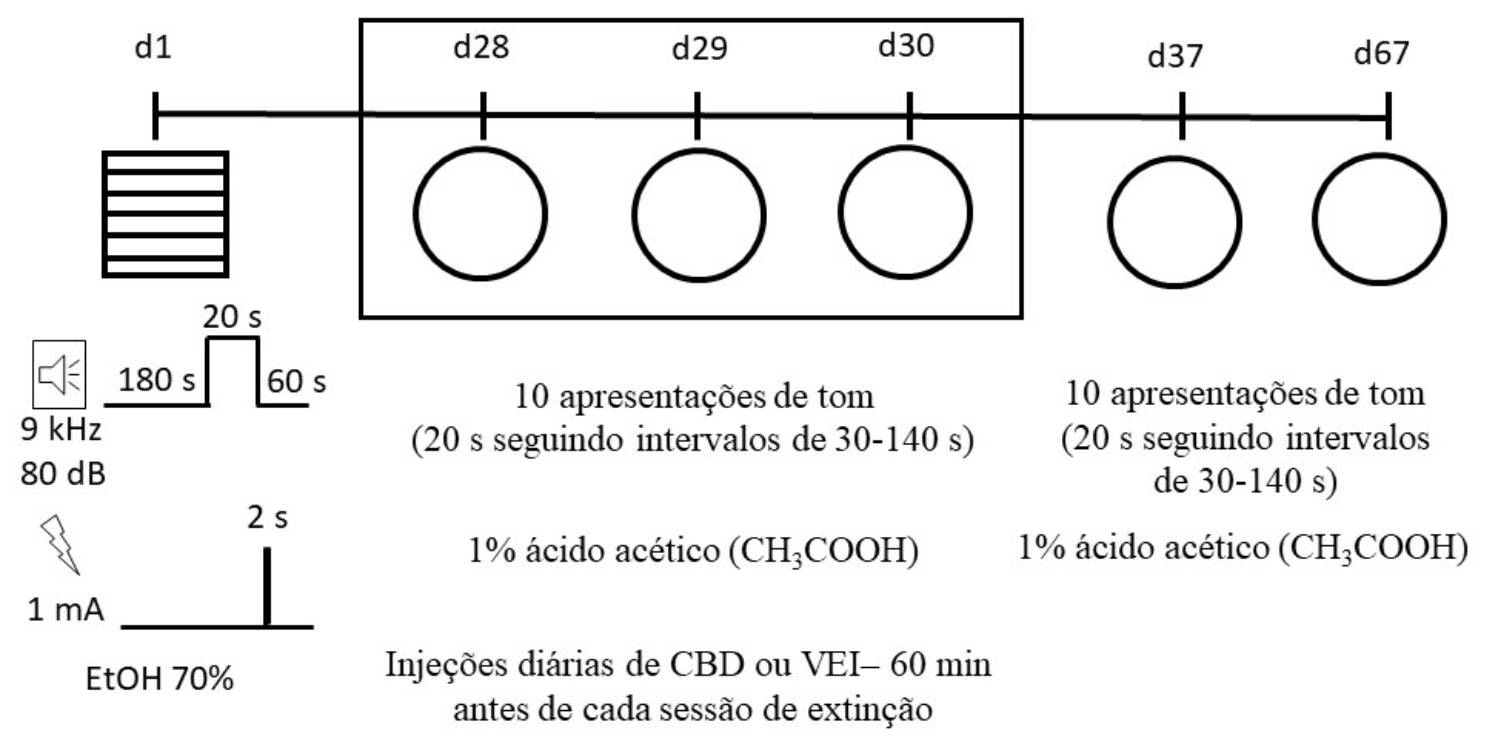

Fig. 8 - Delineamento experimental para o protocolo de medo condicionado ao som ao qual animais HAB e NAB foram submetidos. CBD: canabidiol (15 e $30 \mathrm{mg} / \mathrm{kg})$, VEI: eeículo, d: dia, EtOH: etanol.

Como será visto adiante, diante da ausência de efeitos do tratamento agudo com o CBD nesse modelo, aliado à dificuldade em conseguir um bom número amostral dessas linhagens para experimentos comportamentais, decidimos modificar o plano inicial e interromper o uso dos animais $\mathrm{HAB}$ e NAB. 


\subsubsection{Avaliação dos efeitos do Canabidiol sobre culturas primárias de micróglias estimuladas com LPS}

\subsection{Experimento 18:}

Esse primeiro experimento com cultura celular primária de micróglias foi realizado com o intuito principal de verificar se o CBD estava funcionando ativamente, uma vez que não observamos efeitos da droga nos testes comportamentais feitos previamente.

A metodologia utilizada está descrita na sessão 4.2.5 de material e métodos e as amostras foram submetidas à análise de expressão gênica por PCR em tempo real (sessão 4.2.6.2.). Posteriormente, realizamos outras culturas nas quais uma dose menor de CBD $(1 \mu \mathrm{M})$ também foi utilizada. Entretanto, apenas os resultados do primeiro experimento serão mostrados e discutidos na Tese, uma vez que as amostras dos demais ainda não foram analisadas.

Após a confirmação de que o CBD estava funcionando ativamente, voltamos a testar a droga in vivo.

\subsubsection{Efeitos do Canabidiol em camundongos submetidos ao protocolo de PTSD}

\subsection{Experimento 19:}

$\mathrm{O}$ experimento teve início quando os animais estavam com 12-15 semanas e o procedimento experimental detalhado pode ser verificado na Fig. 9. Vinte e quatro horas após a última injeção de CBD e do teste de expressão de medo, os animais foram eutanasiados e amostras coletadas para análise dos parâmetros imunológicos.

Os resultados oriundos da análise molecular dessas amostras não serão apresentados na tese, uma vez que ainda não foram analisadas. 

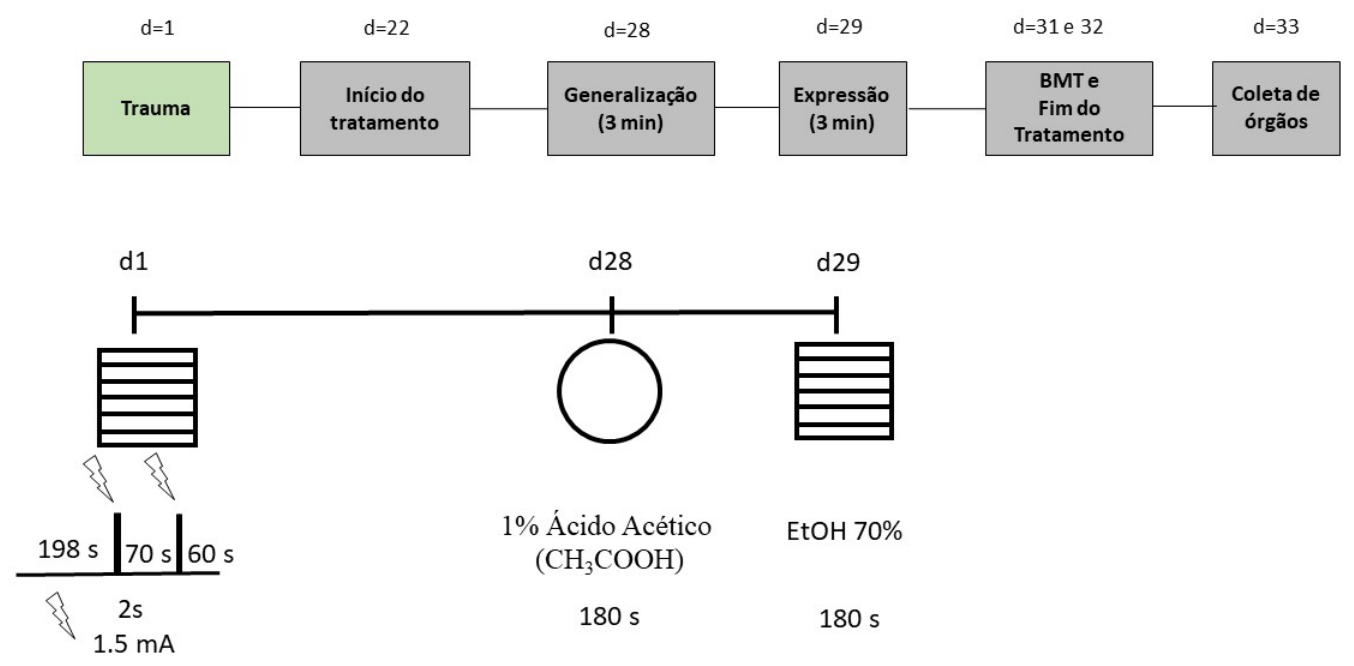

EtOH 70\%

Fig. 9. - Procedimento experimental para avaliação dos efeitos do tratamento repetido com o Canabidiol (10 e $30 \mathrm{mg} / \mathrm{kg}$ ) ou VEI sobre alterações comportamentais induzidas por um modelo animal de PTSD. EtOH: etanol, d: dia; BMT: Teste de mania induzida pelo besouro; PTSD: Transtorno de estresse pós-traumático.

\subsection{Análise Estatística}

Os dados foram inicialmente submetidos à avaliação da distribuição normal de cada variável e à homogeneidade de variâncias. Os dados obtidos estão expressos em média \pm erro padrão da média e analisados por ANOVA de uma via, ANOVA de duas vias, ANOVA para medidas repetidas (ANOVAr) ou ANCOVA. O nível de significância estatístico utilizado foi de 95\% $(\mathrm{p}<0,05)$. As análises estatísticas foram realizadas no software SPSS. 
$\underline{\text { Resultados }}$ 


\section{RESULTADOS}

\section{Experimentos realizados no Brasil}

\subsection{Padronização do modelo de estresse crônico imprevisível por 21 dias}

\subsubsection{Experimento 1:}

O protocolo de estresse utilizado no presente experimento não alterou o peso corpóreo dos animais (Fig. 10A; n=8/grupo). No SPT, os valores basais de preferência foram baixos, inviabilizando a validade e funcionamento do teste (Fig. 10B). De mesmo modo, após o fim do protocolo do CUS, não houve alteração na porcentagem de preferência pela sacarose nos animais de ambos os grupos, estressados e não estressados. Já no teste do LCE, os animais estressados apresentaram maiores porcentagens de tempo (Fig. 10D) e frequência (Fig. 10E) nos braços abertos e menor frequência nos braços fechados (Fig. 10F), sugerindo um efeito tipo-ansiolítico e hipolocomotor do estresse. Entretanto, os animais estressados apresentaram respostas defensivas exacerbadas, como comportamentos de congelamento e/ou fuga, quando adentraram nos braços abertos do LCE, sugerindo que esse efeito tipo-ansiolítico observado poderia ser em decorrência da hipolocomoção induzida pelo estresse. De modo a confirmar essa hipótese, realizamos uma análise de covariância utilizando a distância total percorrida no aparato como covariável e, como esperado, o efeito tipo-ansiolítico deixou de apareceu (dados não mostrados). Ainda neste protocolo, o CUS falhou em aumentar o tempo de imobilidade dos animais no FST (Fig. 10C), a latência para comer na arena (Fig. 2G) e na caixa moradia (Fig. 10H); além de não ter efeito sobre a quantidade total de ração ingerida (Fig. 10I) no teste do NSF. 
A.

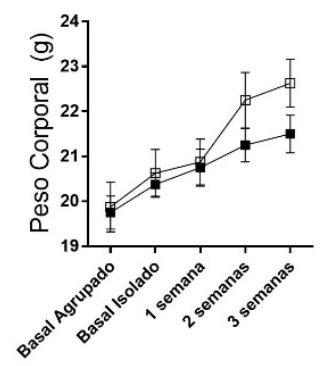

D.

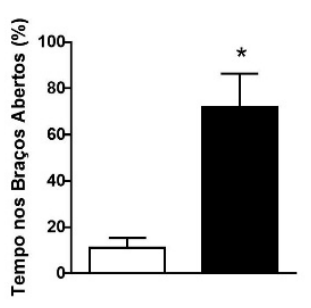

G.

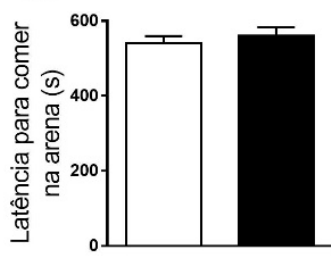

B.

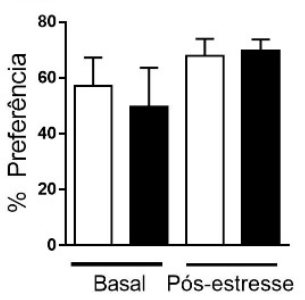

E.

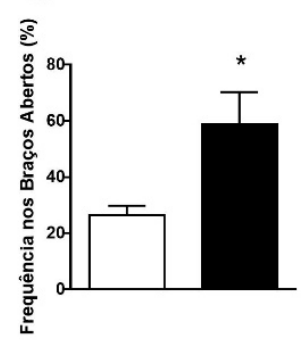

H.

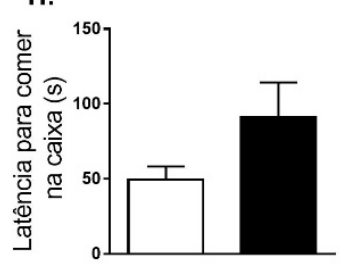

c.

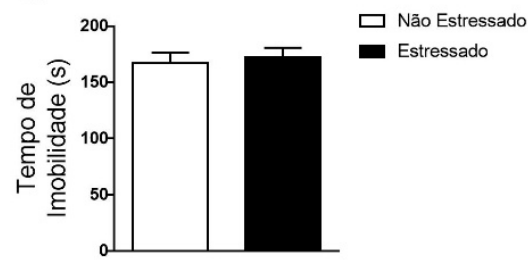

F.

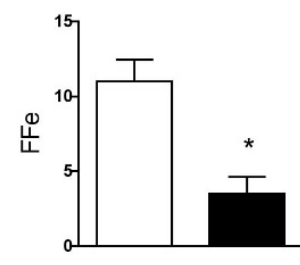

I.

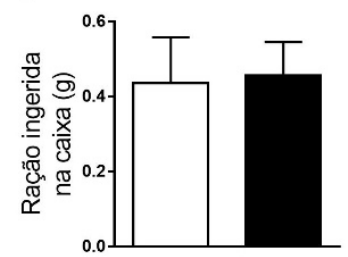

Fig. 10 - Efeitos do estresse crônico imprevisível sobre o peso corporal e sobre parâmetros comportamentais em camundongos (Experimento 1). Camundongos C57BL/6 foram isolados socialmente e submetidos ao protocolo de estresse crônico imprevisível por 21 dias. (A) Peso corporal dos animais ao longo do procedimento experimental. (B) Preferência pela sacarose dos animais antes e após o protocolo de estresse. (C) Tempo de imobilidade dos animais testados no nado forçado. Porcentagens de tempo (D) e frequência (E) dos animais nos braços abertos do labirinto em cruz elevado, bem como a frequência de entradas nos braços fechados do aparato (F). (G) Latência para primeiro episódio de alimentação na arena $(\mathrm{H})$ e na caixa moradia (I) no teste de supressão da alimentação pela novidade. Dados apresentados como Média \pm E.P.M., $n=8$ animais/grupo. ${ }^{*} \mathrm{p}<0,05$ em relação ao grupo não estressado, obtido pelo teste ANOVA de uma via, seguido de post-hoc de Duncan. Peso corporal foi analisado pelo teste ANOVAr.

A partir dos resultados falso-positivos obtidos no teste do LCE com animais estressados, decidimos não mais utilizar esse teste nos próximos experimentos. Além disso, o protocolo de SPT também foi alterado, conforme explicado detalhadamente na sessão de procedimento experimental. 


\subsubsection{Experimento 2:}

Neste experimento, observamos que o estresse reduziu o peso corporal dos animais a partir da $2^{\mathrm{a}}$ semana de estresse (Fig. 11A; n=8/grupo). Apesar da alteração no protocolo, não houve aumento no valor de preferência pela sacarose basal e, novamente, não foi possível observar efeito do estresse nesse teste (Fig. 11B). Como esperado, o teste de campo aberto evidenciou uma robusta hipolocomoção dos animais estressados quando comparados aos animais controles (Fig. 11C). Além disso, houve tendência estatística $(p=0,061)$ do estresse em aumentar a latência para o animal comer na arena do NSF (Fig. 11D). Entretanto, os animais estressados também apresentaram aumento no tempo para se alimentarem na caixa moradia (Fig. 11E) e diminuição na quantia de ração ingerida (Fig. 3F). Finalmente, o tempo de imobilidade dos animais no FST não foi afetado pelo estresse (Fig. 3G).

A.

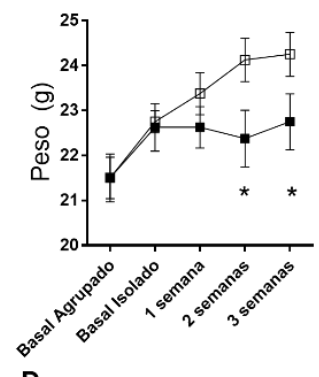

$$
\text { D. }
$$

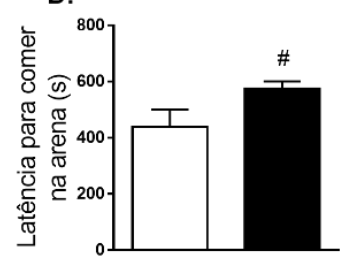

E.

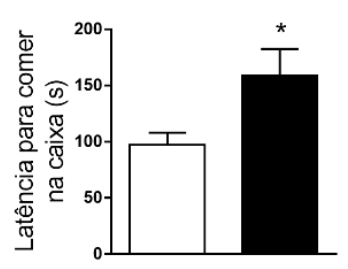

c.
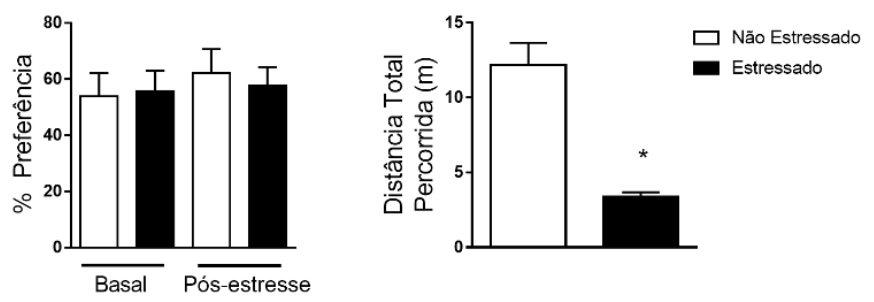

F.

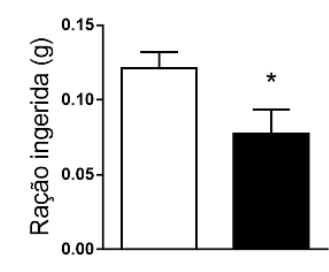

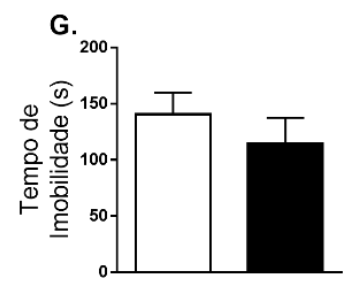

Fig. 11 - Efeitos do estresse crônico imprevisível sobre o peso corporal e parâmetros comportamentais em camundongos (Experimento 2). Camundongos C57BL/6 foram isolados 
socialmente e submetidos ao protocolo de estresse crônico imprevisível por 21 dias. (A) Peso corporal dos animais ao longo do procedimento experimental. (B) Preferência pela sacarose dos animais antes e após o protocolo de estresse. (C) Distância total percorrida pelos animais no teste do campo aberto. Latência para primeiro episódio de alimentação na arena (D) e caixa moradia (E), quantidade de ração ingerida $(\mathrm{F})$ pelos animais no teste de supressão da alimentação pela novidade. (G) Tempo de imobilidade dos animais testados no nado forçado. Dados apresentados como Média \pm E.P.M., $n=8$ animais/grupo. $\# \mathrm{p}<0,07$ em relação ao grupo não estressado; ${ }^{*} \mathrm{p}<0,05$ em relação ao grupo não estressado, obtido pelo teste ANOVA de uma via, seguido de post-hoc de Duncan. (A) *p<0,05 obtido pelo teste ANOVAr.

Curiosamente, os resultados do NSF sugerem que a supressão da alimentação nos animais estressados não ocorre apenas em decorrência da novidade, mas sim de modo geral.

O próximo experimento foi realizado de mesmo modo, exceto pelo teste de preferência pela sacarose que sofreu alterações, conforme descrito anteriormente na sessão de métodos.

\subsubsection{Experimento 3:}

De modo semelhante ao experimento anterior, foi observado a redução de peso corporal dos animais estressados (Fig. 12A; $\mathrm{n}=8-9$ /grupo). O novo protocolo de SPT aumentou a preferência basal dos animais e o estresse crônico diminuiu (Fig. 12B). Novamente, o teste de campo aberto evidenciou a hipolocomoção dos animais estressados quando comparados aos controles (Fig. 12C). Entretanto, os resultados previamente observados no NSF não foram reproduzidos (Fig. 12D-F). Porém, no presente experimento, o CUS aumentou o tempo de imobilidade dos animais (Fig. 12G). 
A.

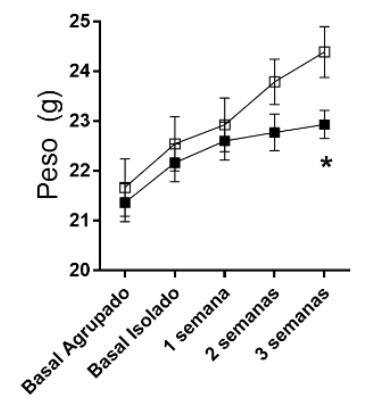

D.

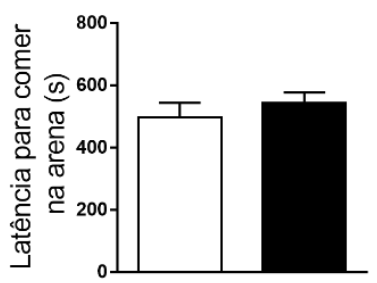

G.

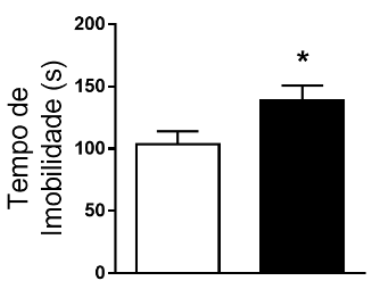

B.

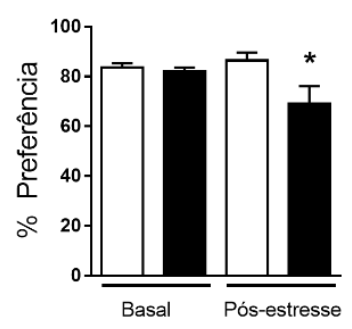

E.

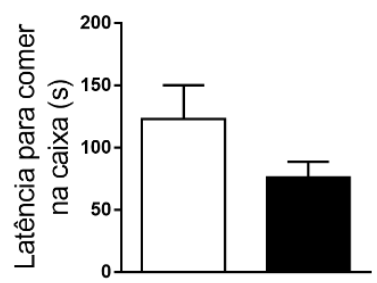

C.

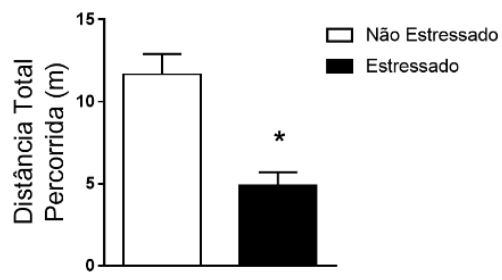

F.

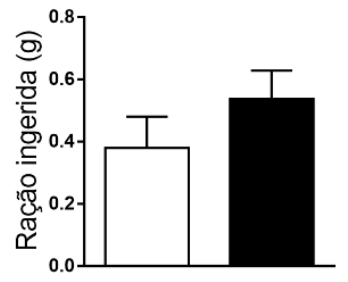

Fig. 12 - Efeitos do estresse crônico imprevisível sobre o peso corporal e parâmetros comportamentais em camundongos (Experimento 3). Camundongos C57BL/6 foram isolados socialmente e submetidos ao protocolo de estresse crônico imprevisível por 21 dias. (A) Peso corporal dos animais ao longo do procedimento experimental. (B) Preferência pela sacarose dos animais antes e após o protocolo de estresse. (C) Distância total percorrida pelos animais no teste do campo aberto. Latência para primeiro episódio de alimentação na arena (D) e caixa moradia (E), quantidade de ração ingerida (F) pelos animais no teste de supressão da alimentação pela novidade. (G) Tempo de imobilidade dos animais testados no nado forçado. Dados apresentados como Média \pm E.P.M., $n=8-9$ animais/grupo. ${ }^{*} \mathrm{p}<0,05$ em relação ao grupo não estressado, obtido pelo teste ANOVA de uma via, seguido de post-hoc de Duncan. (A) * p $<0,05$ obtido pelo teste ANOVAr. (B) *p<0,05 em relação ao grupo não estressado, obtido pelo teste ANCOVA, sendo os valores basais utilizados como covariável.

\subsubsection{Experimento 4:}

A partir desse protocolo, o NSF não foi mais utilizado. O OFT e FST foram realizados com $24 \mathrm{~h}$ de intervalo. O protocolo de SPT foi realizado semanalmente.

Como resultado, observamos a tendência estatística para diminuição do peso corporal dos animais submetidos ao CUS (Fig. 13A; $n=8 /$ grupo; $p=0,065$ ). O protocolo de preferência pela 
sacarose novamente evidenciou a preferência pela sacarose elevada dos animais; entretanto, o estresse não induziu alterações (Fig. 13B). De modo semelhante ao experimento anterior, observamos a hipolocomoção no OFT (Fig. 13C) e aumento no tempo de imobilidade no FST (Fig. 13D) induzidos pelo estresse repetido nos animais cronicamente estressados.

A.

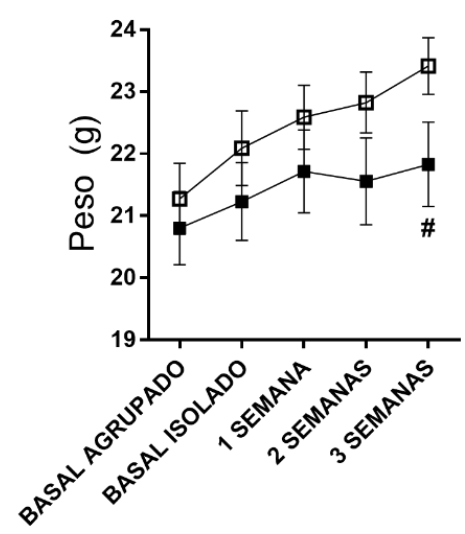

C.

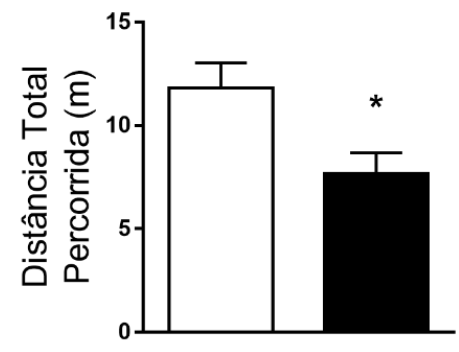

B.

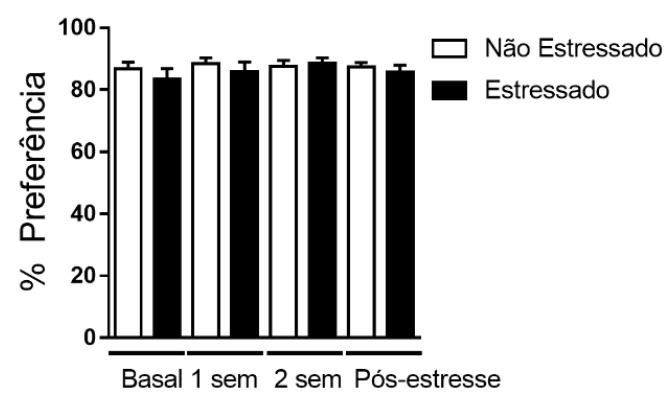

D.

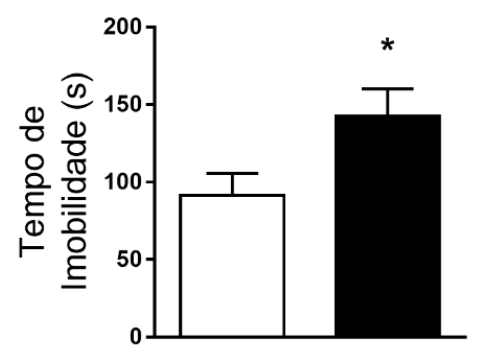

Fig. 13 - Efeitos do estresse crônico imprevisível sobre o peso corporal e parâmetros comportamentais em camundongos (Experimento 4). Camundongos C57BL/6 foram isolados socialmente e submetidos ao protocolo de estresse crônico imprevisível por 21 dias. (A) Peso corporal dos animais ao longo do procedimento experimental. (B) Preferência pela sacarose dos animais antes, durante e após o protocolo de estresse. (C) Distância total percorrida pelos animais no teste do campo aberto. (D) Tempo de imobilidade dos animais testados no nado forçado. Dados apresentados como Média \pm E.P.M., $n=8$ animais/grupo. $\# p<0,07$ em relação ao grupo não estressado, obtido pelo teste ANOVAr. * $\mathrm{p}<0,05$ em relação ao grupo não estressado, obtido pelo teste ANOVA de uma via, seguido de post-hoc deDuncan.

Apesar de termos obtido resultados semelhantes em alguns testes realizados nos experimentos 3 e 4 , vale a pena reforçar que os mesmos foram feitos em tempos diferentes, uma vez que no $3^{\circ}$ experimento ainda havia o NSF.

Diante disso, decidimos realizar um novo experimento, seguindo o mesmo protocolo 
utilizado no experimento 4, porém a SPT foi realizada de modo semelhante ao experimento 3, uma vez que os tempos pré e pós-estresse pareceram funcionar melhor.

\subsubsection{Experimento 5:}

Embora haja tendência gráfica, o efeito do estresse crônico sobre o peso corporal dos animais não foi estatisticamente diferente em comparação ao grupo controle (Fig. 14A; n=78/grupo). O protocolo de preferência pela sacarose continuou evidenciando a elevada preferência dos animais pela solução adocicada; entretanto, ao contrário do observado no experimento 3 , o estresse não teve efeito sobre este parâmetro (Fig. 14B). Conforme observado em todos os experimentos anteriores, o estresse crônico imprevisível induziu hipolocomoção nos animais (Fig. 14C). Entretanto, o efeito do CUS sobre o tempo de imobilidade dos animais, previamente observado nos experimentos 3 e 4, não foi evidenciado neste protocolo (Fig. 14D).

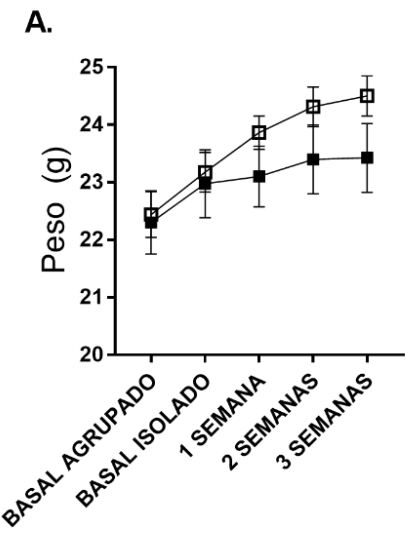

B.
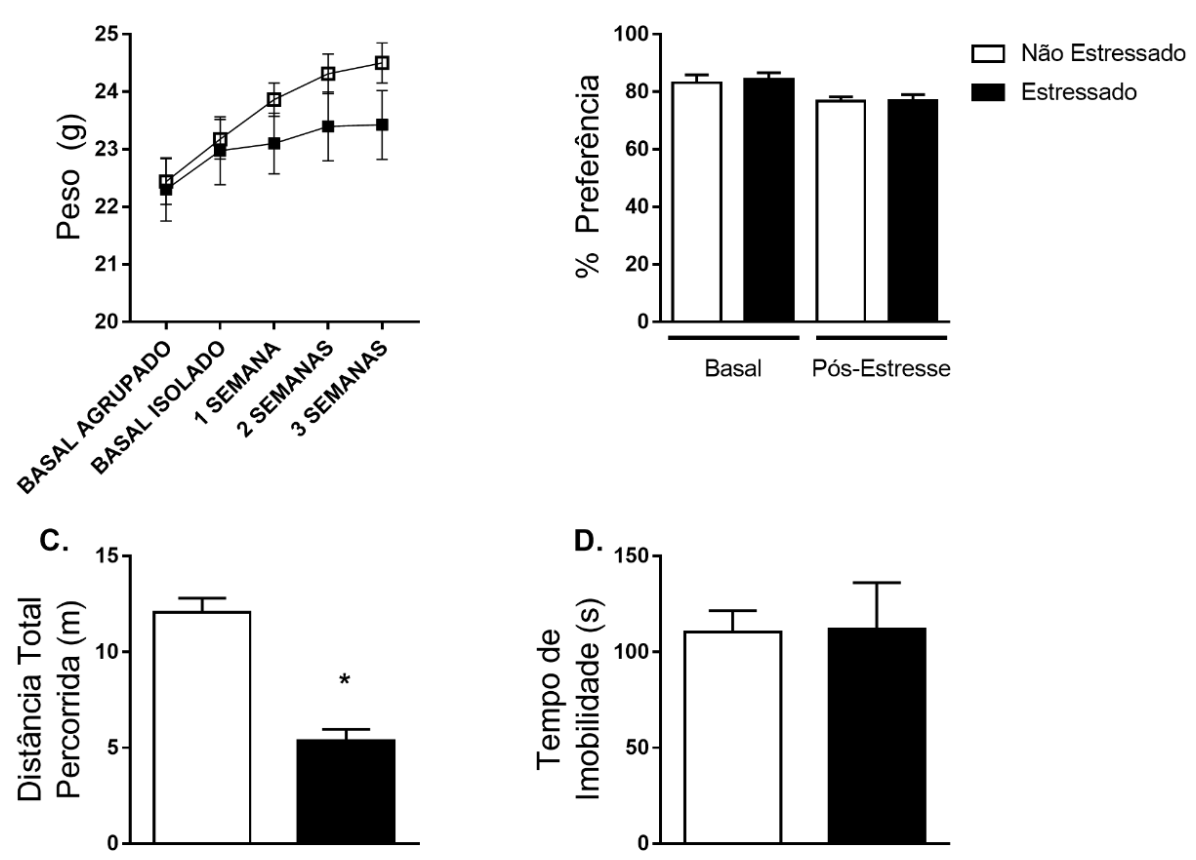

Fig. 14 - Efeitos do estresse crônico imprevisível sobre o peso corporal e parâmetros comportamentais em camundongos (Experimento 5). Camundongos C57BL/6 foram isolados socialmente e submetidos ao protocolo de estresse crônico imprevisível por 21 dias. (A) Peso corporal dos animais ao longo do procedimento experimental. (B) Preferência pela sacarose dos animais antes e após o protocolo de estresse. (C) Distância total percorrida pelos animais no teste do campo aberto. (D) Tempo de imobilidade dos animais testados no nado forçado. Dados apresentados como Média \pm E.P.M., n=7-8 animais/grupo. 
${ }^{*} \mathrm{p}<0,05$ em relação ao grupo não estressado, obtido pelo teste ANOVA de uma via, seguido de post-hoc de Duncan.

Os resultados obtidos no presente experimento não reproduziram os obtidos no anterior exceto pela hipolocomoção novamente observada no OFT. Então, considerando 1) que a arena foi o único teste comportamental capaz de detectar as consequências comportamentais promovidas pelo estresse, apesar de termos utilizado outros 2 testes e 2) que não houve efeito estatístico na diminuição do peso corporal dos animais estressados, chegamos à conclusão de que, no presente experimento, o protocolo de estresse não foi efetivo como nos experimentos anteriores.

De modo a dar andamento ao projeto, resolvemos avaliar a expressão relativa de genes que compõem o inflamassoma de NLRP3, além das dosagens séricas e estrutura-específicas de citocinas, para verificar como estavam os parâmetros imunológicos. Para isso, desconsideramos diferenças nos protocolos experimentais e utilizamos amostras de animais testados nos experimentos 3 e 4 . As amostras foram divididas aleatoriamente para análise de expressão gênica ou dosagem de citocinas.

\subsection{Expressão relativa de genes relacionados à plataforma do inflamassoma de NLRP3 e dosagens séricas e estrutura-específicas de IL-1ß para padronização das alterações moleculares induzidas pelo CUS}

\subsubsection{Experimento 6:}

Ocorreu interação significativa entre região e estresse na expressão gênica de NLRP3 com os normalizadores $b$-Act e Gapdh nas regiões do HIP e CPF (Fig. 15A, 15C, 15D e 15F, b-Act, $\mathrm{F} 1,5=36,6, \mathrm{p}=0,002 ;$ Gapdh, $\mathrm{F} 1,5=8,7, \mathrm{p}=0,032)$, com o estresse diminuindo a expressão no CPF $\left({ }^{*} \mathrm{p}<0,05\right)$ e tendendo a aumentar no hipocampo $\left({ }^{\#} \mathrm{p}=0,09\right)$. Em relação à Caspase-1, o padrão foi semelhante, mas não houve efeito significativo, possivelmente pela não homogeneidade de variâncias. Em relação à expressão de ASC (Pycard), ocorreu apenas efeito da estrutura com $b$ Act como normalizador, apresentando uma expressão maior do gene Pycard no CPF quando 
comparado com HIP e EST. No que se refere à expressão gênica de $I l-1 b$, como não houve níveis detectáveis na região do $\mathrm{CPF}$, não houve análise de interação entre esta estrutura e as demais. Na região do HIP, não houve efeito do estresse sobre esse parâmetro. Os efeitos do estresse crônico sobre os transcritos de genes-alvo para Nlrp3, Pycard e Casp1 não foram evidentes no EST (Fig. 15B e 15E) quando normalizados tanto por $b$-Act quanto por Gapdh (n=3-4/grupo). Entretanto, para $I l-1 b$ foi observado uma tendência gráfica para aumento na expressão relativa deste gene no grupo estressado em comparação com o não estressado - porém, não houve efeito significativamente estatístico, provavelmente pela ausência de homocedasticidade.

\section{b-Act}

A.

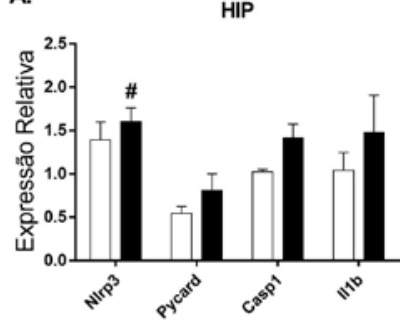

B.

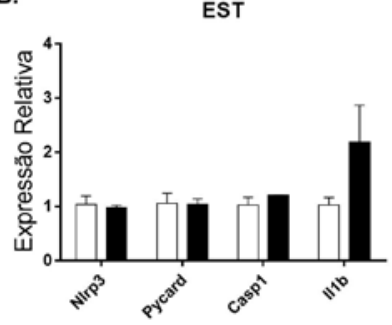

c.<smiles>C1CCCC1</smiles>

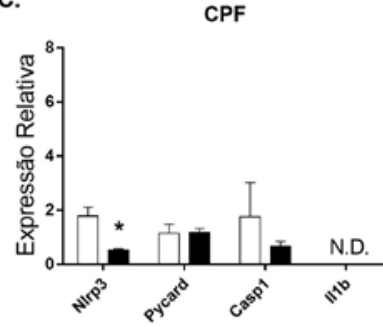

$\square$ Não Estressado

Estressado

\section{Gapdh}

D.

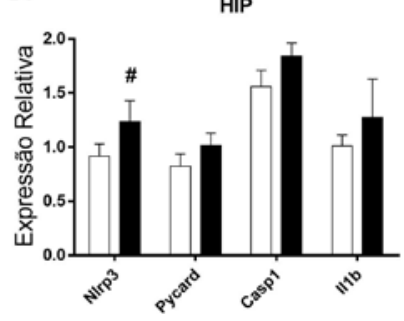

E.

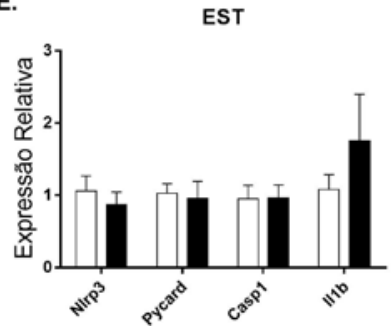

F.

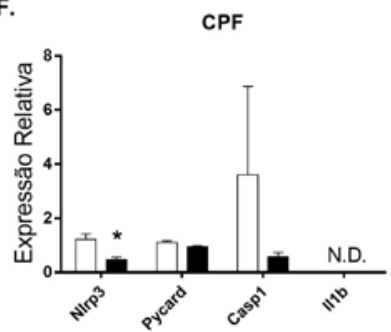

Fig. 15 - Efeitos do estresse crônico imprevisível sobre a expressão relativa de genes envolvidos com a plataforma do inflamassoma de NLRP3. Camundongos C57BL/6 foram isolados socialmente e submetidos ao protocolo de estresse crônico imprevisível por 21 dias. Após o último teste comportamental, foram eutanasiados e as regiões do Hipocampo (HIP; A e D), Estriado (EST; B e E) e Córtex Pré-Frontal ventromedial (CPF; C e F) retiradas. O RNAm dos tecidos foi extraído e submetido à reação de RT-PCR para confecção de cDNA. Posteriormente, o material foi submetido à análise de expressão gênica pelo método de TaqMan. Os dados representam a expressão relativa em função dos genes controles b-Act ou Gapdh calculados através do método $\Delta \Delta \mathrm{Ct}$. Pycard: ASC; Casp1: Caspase-1. Dados apresentados como Média \pm E.P.M., n=3-4 animais/grupo. ${ }^{*} \mathrm{p}<0,05$ em relação ao grupo não estressado, obtido pelo teste ANOVA de uma via.

Com relação à dosagem de IL-1 $\beta$ sérica e nas regiões alvo cerebrais, não houve efeito do 
estresse (Fig. 16).

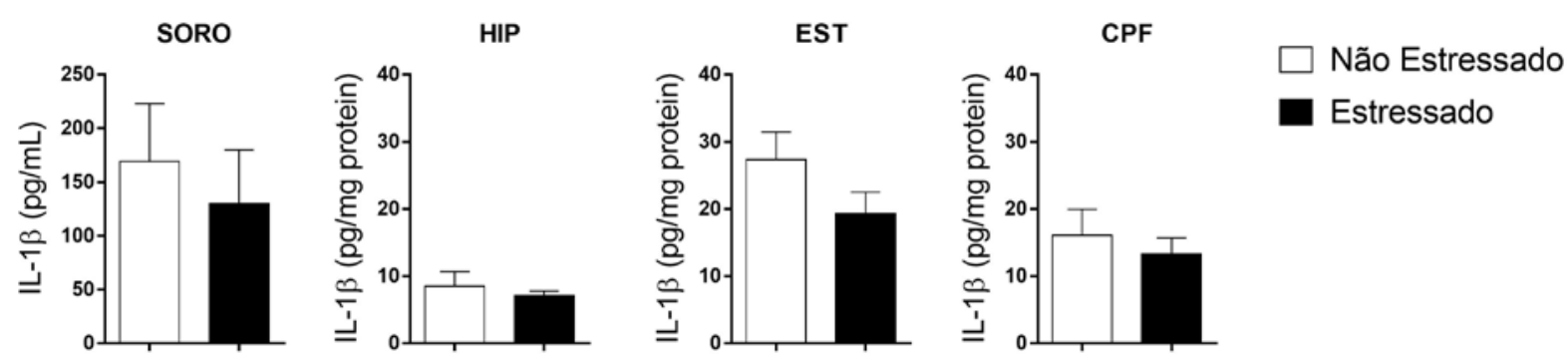

Fig. 16 - Efeitos do estresse crônico imprevisível sobre os níveis de IL-1ß no soro e regiões cerebrais de camundongos. Camundongos $\mathrm{C} 57 \mathrm{BL} / 6$ foram isolados socialmente e submetidos ao protocolo de estresse crônico imprevisível por 21 dias. Após o último teste comportamental, foram eutanasiados e as regiões do Hipocampo (HIP), Estriado (EST) e Córtex Pré-Frontal ventromedial (CPF) retiradas e congeladas. Posteriormente, o material foi homogeneizado e submetido à análise pelo método de ELISA. Dados apresentados como Média \pm E.P.M., $\mathrm{n}=4-6$ animais/grupo.

A partir das diferenças observadas nos experimentos que avaliavam a expressão gênica dos componentes da plataforma do inflamassoma de NLRP3, no experimento seguinte começamos, também, a investigar os efeitos do CBD. Conforme explicado na sessão de delineamento experimental, houve mudança no protocolo experimental, de modo que optamos por dar pausa de um dia entre o término do protocolo de estresse e tratamento para a realização do primeiro teste comportamental. Desse modo, todos os testes foram realizados na ausência de CBD circulante, permitindo-nos inferir que quaisquer efeitos observados seriam em decorrência do tratamento repetido e não agudo.

\subsection{Avaliação dos efeitos do Canabidiol sobre as alterações comportamentais induzidas pelo estresse crônico imprevisível}

\subsubsection{Experimento 7:}

Não houve efeito do estresse e/ou do tratamento com o CBD (30 mg/kg) sobre o peso corporal dos animais (Fig. 17A; n=4/grupo). De mesmo modo, o protocolo de preferência pela sacarose não foi influenciado pelo estresse, nem pelo tratamento com CBD (Fig. 17B). Conforme 
observado em todos os experimentos anteriores, o estresse crônico imprevisível induziu hipolocomoção nos animais e, apesar da tendência gráfica, o CBD melhorou essa condição (Fig. 17C). Novamente, o protocolo de CUS falhou em alterar o tempo de imobilidade dos animais no FST, assim como a exposição ao CBD (Fig. 17D).
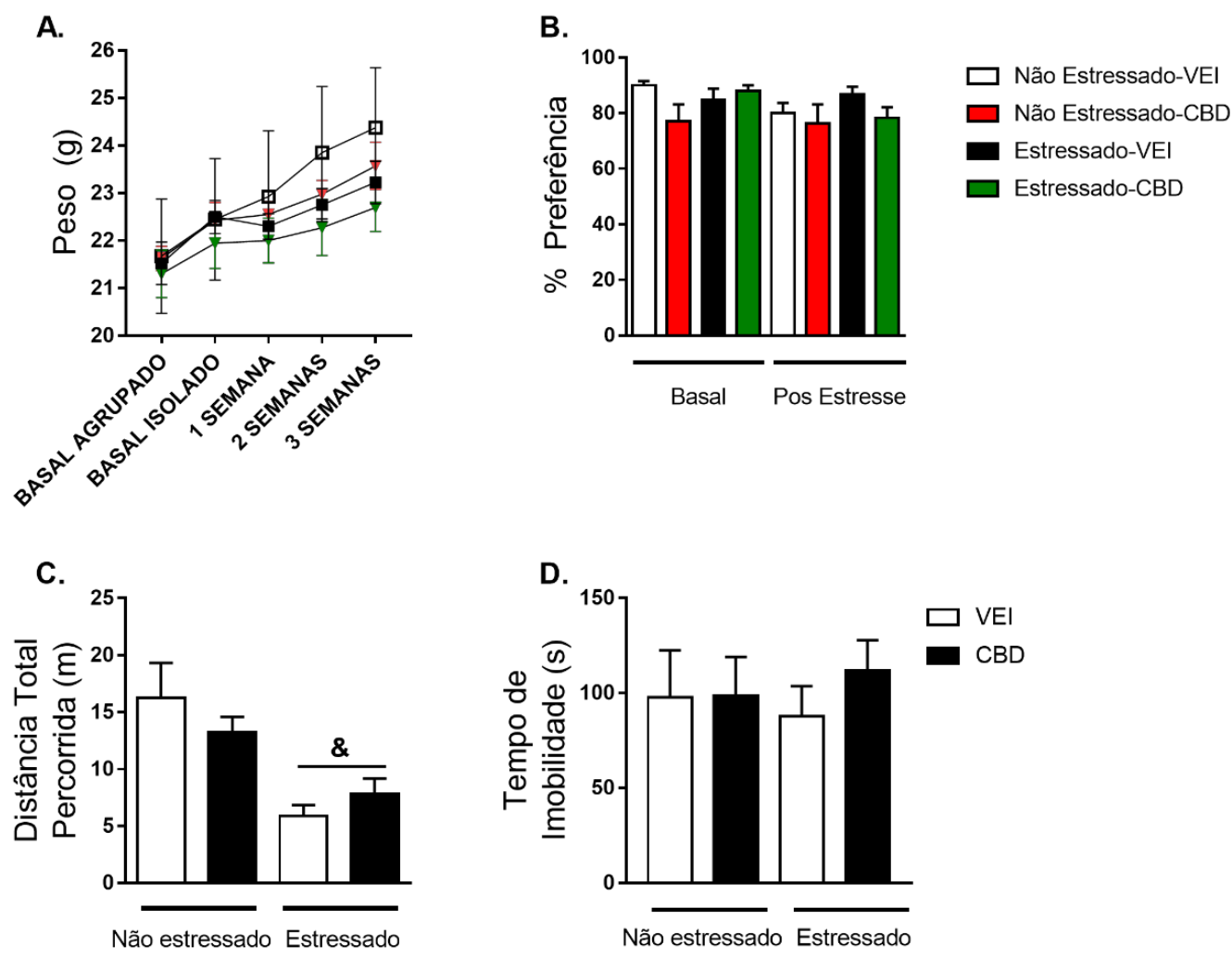

Fig. 17 - Efeitos do estresse crônico imprevisível e do tratamento com o canabidiol sobre o peso corporal e parâmetros comportamentais em camundongos. Camundongos C57BL/6 foram isolados socialmente e submetidos ao protocolo de estresse crônico imprevisível por 21 dias. Os animais receberam injeções intraperitoneais diárias de VEI $(10 \mathrm{ml} / \mathrm{kg})$ ou CBD $(30 \mathrm{mg} / \mathrm{kg})$ 2-3 h após o término do protocolo de estresse. (A) Peso corporal dos animais ao longo do procedimento experimental. (B) Preferência pela sacarose dos animais antes e após o protocolo de estresse e injeções. (C) Distância total percorrida pelos animais no teste do campo aberto. (D) Tempo de imobilidade dos animais testados no nado forçado. Dados apresentados como Média \pm E.P.M., $\mathrm{n}=4$ animais/grupo. $\& \mathrm{p}<0,05$ em relação ao grupo não estressado, obtido pelo teste ANOVA de duas vias, sendo estresse e tratamento os fatores. VEI: Veículo. CBD: Canabidiol.

A partir do próximo experimento, os animais foram mantidos agrupados e não mais isolados socialmente. Além disso, o teste de preferência pela sacarose também deixou de ser utilizado, conforme explicado na sessão 4.1.6.3.1. 


\subsubsection{Experimento 8:}

Não houve efeito do estresse e/ou do tratamento sobre o peso corporal dos animais (Fig. 18A). Apesar de graficamente haver uma diferença entre os grupos veículo NÃO CUS e CUS, não há diferença estatisticamente, provavelmente por conta da variabilidade entre os grupos. Novamente, o CUS induziu tendência a um falso efeito tipo-ansiolítico nos animais submetidos ao LCE, caracterizado pelo aumento da porcentagem de tempo nos braços abertos do aparato, quando comparado ao grupo NÃO CUS-VEI (Fig. 18B). Esse potencial efeito pode decorrer do fato de os animais estressados apresentarem respostas emocionais defensivas exacerbadas, como comportamentos de congelamento e/ou fuga, quando adentraram nos braços abertos do LCE, sugerindo que esse efeito tipo-ansiolítico observado poderia ser em decorrência da hipolocomoção induzida pelo estresse. Neste protocolo, o CUS induziu hipolocomoção nos animais no teste do campo aberto (Fig. 18E), porém falhou em aumentar o tempo de imobilidade dos animais no teste do nado forçado (Fig. 18F). Não houve efeito do tratamento com CBD em nenhum dos testes. 

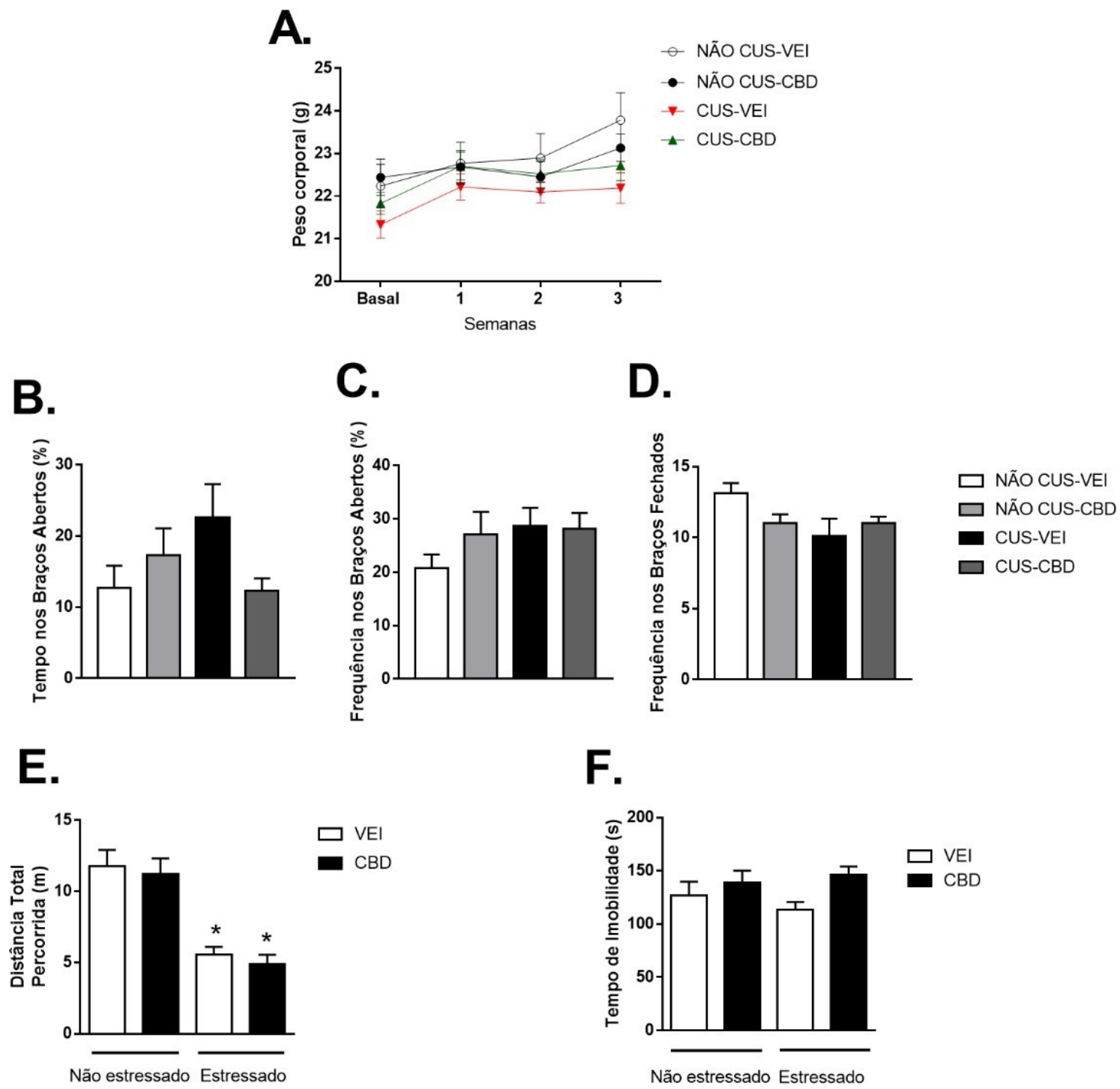

F.

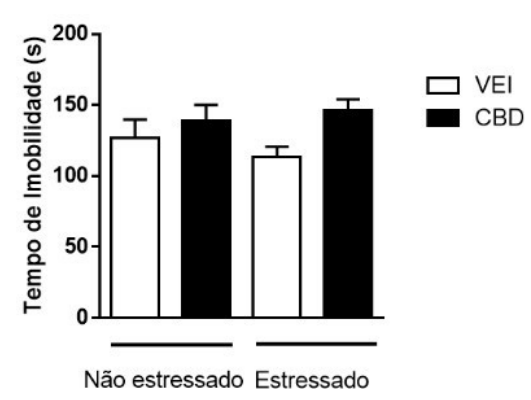

Fig. 18 - Efeitos do estresse crônico imprevisível e tratamento com canabidiol sobre o peso corporal e sobre parâmetros comportamentais em camundongos. Camundongos C57BL/6 foram mantidos em 5/caixa e submetidos ao protocolo de estresse crônico imprevisível (CUS) por 21 dias. Os animais receberam injeções intraperitoneais diárias de VEI ou CBD $(30 \mathrm{mg} / \mathrm{kg})$ 2-3 h após o término do protocolo de estresse. (A) Peso corporal dos animais ao longo do procedimento experimental. (B) Porcentagens de tempo e (C) frequência nos braços abertos do labirinto em cruz elevado, bem como a frequência de entradas nos braços fechados do aparato (D). (E) Distância total percorrida pelos animais no teste do campo aberto e (F) tempo de imobilidade dos animais no teste de nado forçado. Dados apresentados como Média \pm E.P.M., $n=10$ animais/grupo. ${ }^{*} \mathrm{p}<0,05$ em relação ao grupo não estressado, obtido pelo teste ANOVA de uma via, seguido de post-hoc de Duncan. CBD: Canabidiol (30 mg/kg); VEI: Veículo (10 ml/kg).

Novamente, levando em conta a tendência para resultados falso-positivos de animais isolados e agrupados submetidos ao CUS e ao teste do LCE, optamos por não mais utilizar o LCE em animais expostos ao estresse crônico imprevisível no presente projeto. Além disso, no 
experimento seguinte, os animais seriam testados na arena antes e após o protocolo de estresse e adicionamos o tratamento repetido com Fluoxetina (FLX, $10 \mathrm{mg} / \mathrm{kg}$ ).

\subsubsection{Experimento 9:}

Nesse experimento, o CUS alterou o peso corpóreo dos animais, assim como os tratamentos (Fig. 19A; n=10/grupo). De modo semelhante, a nível comportamental, pela primeira vez em todos os experimentos realizados, o CUS não induziu a hipolocomoção previamente observada (Fig. 19B). Houve apenas efeito do tempo (basal x pós- estresse) na locomoção dos animais, porém não houve efeito nem de tratamento, nem do estresse. No teste do nado forçado, entretanto, a FLX (10 mg/kg) induziu um efeito tipo- depressivo nos animais não estressados e estressados (Fig. 19C).

A.

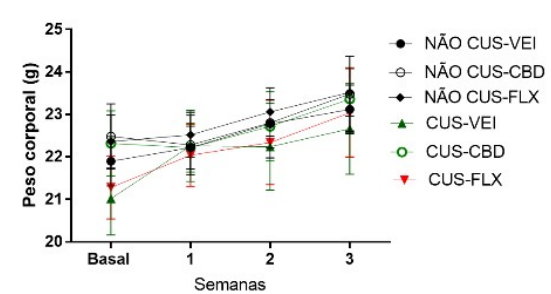

B.

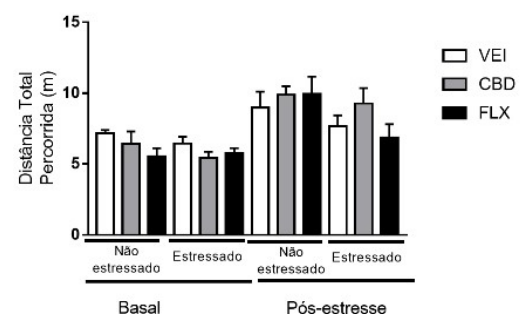

C.

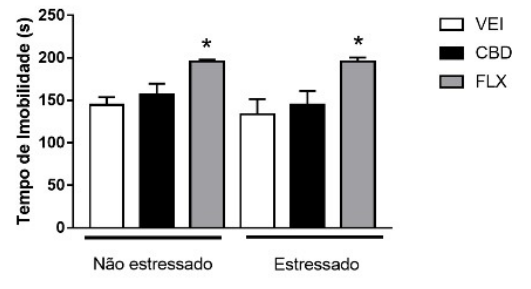

Fig. 19 - Efeitos do estresse crônico imprevisível e tratamento repetido com canabidiol ou fluoxetina sobre o peso corporal e parâmetros comportamentais em camundongos. Camundongos C57BL/6 foram mantidos agrupados (5/caixa) e submetidos ao protocolo de estresse crônico imprevisível por 21 dias. Os animais receberam injeções intraperitoneais diárias de VEI $(10 \mathrm{ml} / \mathrm{kg}), \mathrm{CBD}(30 \mathrm{mg} / \mathrm{kg}), \mathrm{FLX}(10 \mathrm{mg} / \mathrm{kg})$ 2-3 h após o término do protocolo de estresse. A) Peso corporal dos animais ao longo do procedimento experimental. (B) Distância total percorrida pelos animais no teste do campo aberto. (C) Tempo de imobilidade dos animais testados no nado forçado. Dados apresentados como Média \pm E.P.M., $n=10$ animais/grupo. ${ }^{*} \mathrm{p}<0,05$ em relação ao grupo veículo, obtido pelo teste ANOVA de uma via, seguido de post-hoc de Duncan.VEI: Veículo, CBD: Canabidiol, FLX: Fluoxetina.

Considerando a falta de efeito do estresse e/ou dos tratamentos nos experimentos descritos nessa fase do projeto, optamos por não conduzir as análises moleculares nos tecidos obtidos dos animais - uma vez que não conseguiríamos correlacionar os dados comportamentais com os moleculares.

Conforme explicado na sessão 4.1.6.3.3. de Delineamento experimental, testamos outros 
modelos de estresse e passamos a utilizar o modelo único de estresse por restrição.

\subsection{Padronização do modelo de estresse único por restrição}

\subsubsection{Experimento 10:}

O protocolo de estresse único por restrição diminuiu a porcentagem de tempo e frequência dos animais no teste do labirinto em cruz elevado (Fig. 20), sem alterar a frequência de entrada nos braços fechados (dados não mostrados), em animais testados no dia seguinte ao estresse.

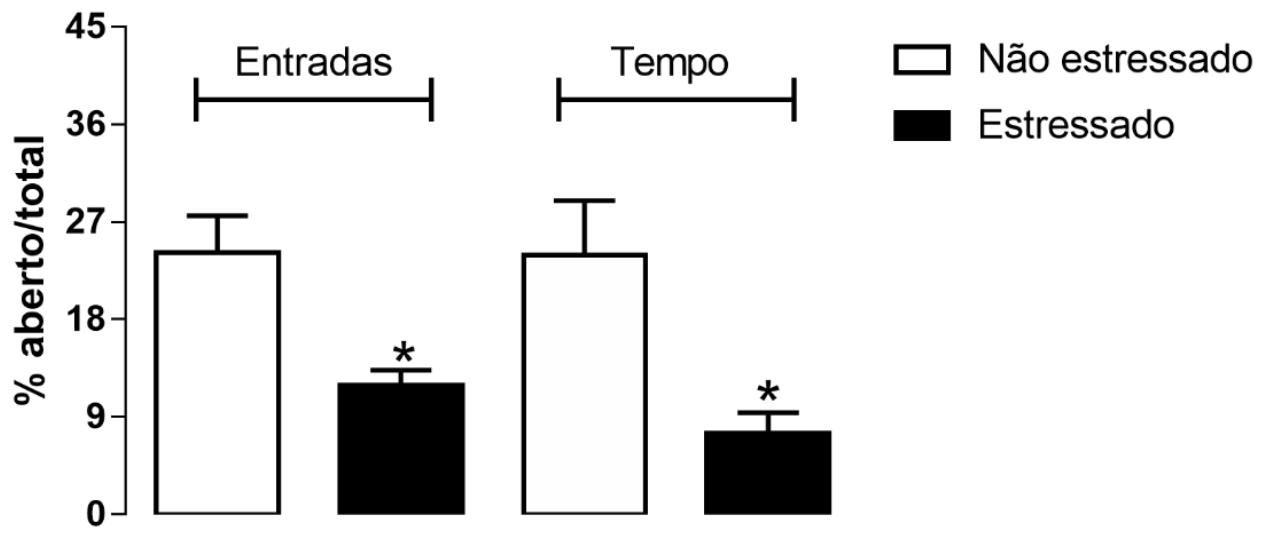

Fig. 20 - Efeitos do estresse único por restrição sobre a porcentagem de tempo e entradas nos braços abertos em camundongos submetidos ao teste do labirinto em cruz elevado. Camundongos C57BL/6 foram mantidos agrupados (5/caixa) e submetidos ao protocolo de estresse único por restrição. Após o término do protocolo, os animais foram mantidos isolados socialmente até o dia seguinte, para a realização do teste comportamental. Dados apresentados como Média \pm E.P.M., $n=13-15$ animais/grupo. ${ }^{*} \mathrm{p}<0,05 \mathrm{em}$ relação ao grupo não estressado, obtido pelo teste ANOVA de uma via.

Diante dos resultados positivos neste modelo, realizamos novos experimentos para avaliar os efeitos duradouros do estresse ( 7 dias) tanto no teste de suspensão pela cauda quanto no teste do labirinto em cruz elevado; bem como o tratamento agudo e/ou repetido com o CBD em diferentes doses $(15$ e $30 \mathrm{mg} / \mathrm{kg})$.

\subsubsection{Experimentos 11, 12, 13:}

Os resultados aqui apresentados, são provenientes de 3 experimentos independentes, nos quais utilizamos a dose de $30 \mathrm{mg} / \mathrm{kg}$ de CBD tanto no protocolo de tratamento agudo quanto repetido. Como resultado, observamos que o estresse único por restrição induziu um efeito tipo- 
ansiogênico nos animais, caracterizado pela diminuição no tempo de permanência nos braços abertos do LCE (Fig. 21A); sem alterar a frequência de entrada nos braços abertos (Fig. 21B) e nos braços fechados (Fig. 21C).

De modo bastante interessante, a administração repetida do CBD na dose de $30 \mathrm{mg} / \mathrm{kg}$ induziu tendência a um efeito tipo-ansiogênico em animais não estressados e tipo-ansiolítico em animais estressados no teste do LCE (Fig. 21 A).

Não houve efeito do estresse ou tratamento sobre o tempo de imobilidade dos animais no TST (Fig. 21D) e no peso corporal (Fig. 21E)
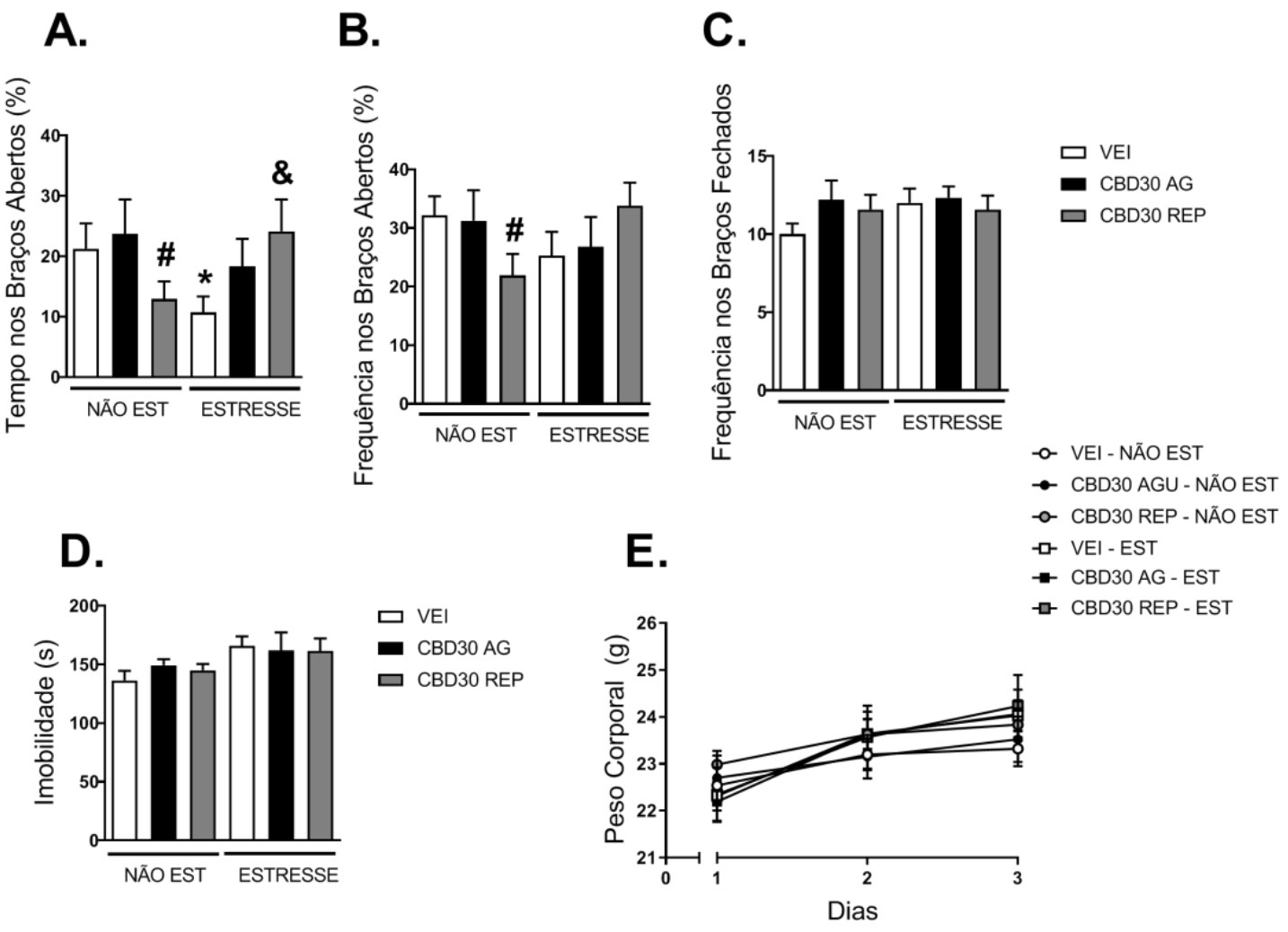

Fig. 21 - Efeitos do estresse único por restrição e do tratamento com o canabidiol em camundongos submetidos ao teste do labirinto em cruz elevado, suspensão pela cauda e peso corporal. Camundongos C57BL/6 foram mantidos agrupados (5/caixa) e submetidos ao protocolo de estresse único por restrição. Após o término do protocolo, os animais foram mantidos isolados por 7 dias, até a realização dos testes comportamentais. A administração do Vei ou CBD $30 \mathrm{mg} / \mathrm{kg}$ foi realizada de modo agudo ou repetido. No caso do tratamento agudo, a administração do Vei ou CBD $30 \mathrm{mg} / \mathrm{kg}$ foi 2 a $3 \mathrm{~h}$ após o término do estresse e, nos dias subsequentes, os animais receberam Vei por via intraperitoneal. No esquema repetido, a injeção por via intraperitoneal de CBD ou Vei ocorreu diariamente - no primeiro dia, entre 2-3 h após o término do 
estresse e, no último dia, aproximadamente $20 \mathrm{~h}$ antes do teste comportamental. Dados apresentados como Média \pm E.P.M., $\mathrm{n}=10-12$ animais/grupo. *p $<0,05$ em comparação com o grupo Vei-Não Est, $\# \mathrm{p}<0.07$ em comparação com o grupo Vei-Não Est, $\& p<0,05$ em comparação com o grupo Vei- Est obtido pelo teste ANOVA de duas vias.

Diante desse efeito, decidimos testar a dose de $15 \mathrm{mg} / \mathrm{kg}$ do CBD uma vez que o composto utilizado no presente estudo possui uma pureza maior que os de trabalhos anteriores de nosso grupo de pesquisa. Portanto, poderia haver alteração na dose efetiva em comparação com trabalhos anteriores. Além disso, optamos por testar os animais no protocolo do Medo Condicionado ao Contexto (MCC) - uma vez que não houve efeito do estresse no teste de suspensão pela cauda.

\subsubsection{Experimentos 14, 15 e 16:}

Conforme descrito na sessão 4.1.6.4.3. os experimentos realizados com a dose de 15 $\mathrm{mg} / \mathrm{kg}$ de CBD não serão mostrados, uma vez que que o modelo de estresse que vinha sendo utilizado e nos fornecendo dados robustos, parou de funcionar provavelmente por do déficit nutricional dos animais.

Diante disso, a minha bolsa de Doutorado sanduíche para permanecer um ano no Instituto Max-Planck de Psiquiatria foi aprovada pela FAPESP. Com isso, decidimos avaliar os efeitos do tratamento agudo com o CBD em animais que apresentam comportamento tipo-ansioso naturalmente $(\mathrm{HAB})$ ou não $(\mathrm{NAB})$; de modo a evitar eventuais problemas com protocolos de estresse e conduzir experimentos de forma mais rápida.

\section{Experimentos realizados na Alemanha}

\subsection{Avaliação dos efeitos Canabidiol sobre parâmetros comportamentais e imunológicos em um modelo psicopatológico genético de ansiedade}

\subsubsection{Experimento 17:}

Como resultado, observamos que os animais $\mathrm{HAB}$ apresentam aumento de comportamentos relacionados a ansiedade no teste do LCE (Fig. 22), através do aumento da 
latência para primeira entrada nos braços abertos (Fig. 22A) e do tempo de permanência nos braços fechados do aparato (Fig. 22D). Entretanto, apesar da tendência estatística com a maior dose de $\mathrm{CBD}$, o tratamento agudo com este fitocanabinoide reverteu esses parâmetros de modo significativo.

A.

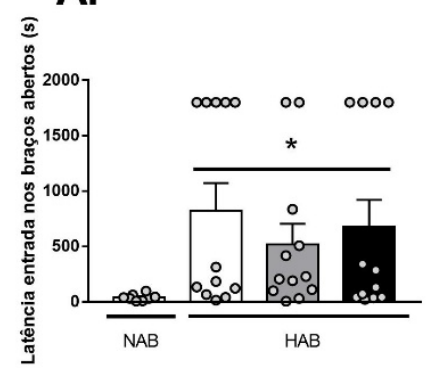

C.

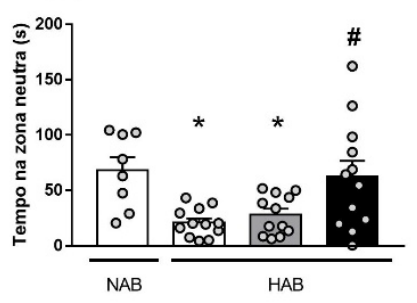

E.

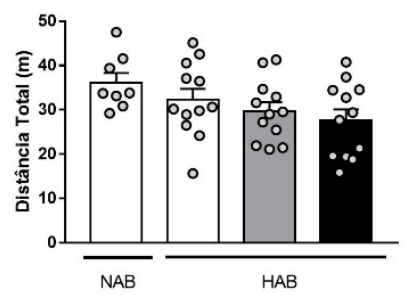

B.

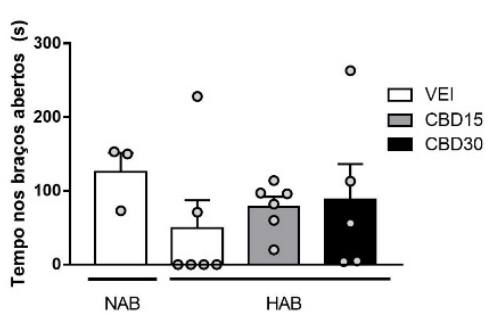

D.

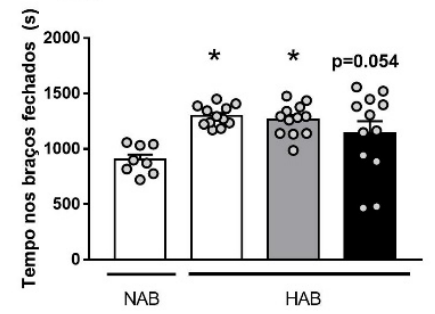

Fig. 22 - Efeitos do tratamento agudo com o canabidiol em camundongos HAB e NAB avaliados no teste do labirinto em cruz elevado (LCE). Camundongos HAB e NAB foram mantidos agrupados (4-5/caixa) e, no dia do experimento, receberam a administração do Veículo (Vei, $10 \mathrm{mg} / \mathrm{kg}$ ) ou Canabidiol (CBD; 15 ou $30 \mathrm{mg} / \mathrm{kg}$ ) por via intraperitoneal. Dados apresentados como Média \pm E.P.M., $n=8-12$ animais/grupo. ${ }^{*} \mathrm{p}<0,05$ em comparação com o grupo NAB, $\# \mathrm{p}<0.07$ em comparação com o grupo HAB-VEI e HAB-CBD15 obtido pelo teste ANOVA de uma via, seguido por post-hoc de Duncan.

De modo semelhante, no teste de mania induzida pelo besouro os animais HAB apresentaram um aumento na porcentagem de respostas de esquivas após o contato com o besouro, quando comparados aos camundongos NAB (Fig. 23C). O tratamento com o CBD na dose 
intermediária tendeu a diminuir ( $<<0,07 ; \mathrm{n}=12$ animais/grupo) o número de respostas ativas do animal após o contato com o robô.

Não houve diferença na capacidade exploratório de ambos os grupos, durante a fase de habituação à arena (Fig. 23A). De modo semelhante e esperado, não houve diferença entre o número de contatos do robô e os animais de todos os grupos experimentais (Fig. 23B).
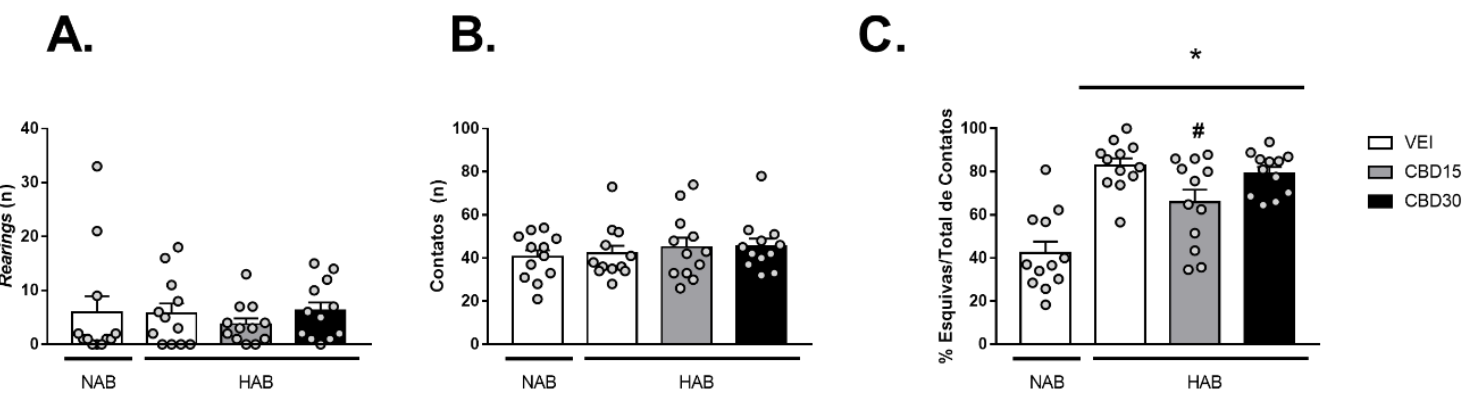

Fig. 23 - Efeitos do tratamento agudo com o canabidiol em camundongos HAB e NAB avaliados no teste de mania induzida pelo besouro (BMT). Camundongos HAB e NAB foram mantidos agrupados (45/caixa) e no dia do experimento receberam a administração do Vei ou CBD (15 ou $30 \mathrm{mg} / \mathrm{kg}$ ) por via intraperitoneal. Dados apresentados como Média \pm E.P.M., $n=12$ animais/grupo. ${ }^{*} \mathrm{p}<0,05$ em comparação com o grupo NAB, $\#$ p $<0.07$ em comparação com o grupo HAB-VEI e HAB-CBD30 obtido pelo teste ANOVA de uma via.

No teste de MCC observamos que, independentemente da linhagem, os animais não apresentaram comportamento de freezing nos 20 segundos que antecederam a primeira apresentação do estímulo condicionado (tom; EC). Entretanto, durante a primeira apresentação do EC, os animais HAB apresentaram aumento no tempo de congelamento em comparação com os animais $\mathrm{NAB}\left({ }^{*} \mathrm{p}<0,05\right.$ obtido pelo teste ANOVA de uma via seguido pelo pós-teste de Duncan, $\mathrm{n}=11-12$ /grupo). O processo de 3 dias de extinção, diminuiu o tempo total de freezing apresentado por ambas as linhagens $\left({ }^{*} \mathrm{p}<0,05\right.$ obtido pelo teste ANOVAr, $\mathrm{n}=11-12 /$ grupo); entretanto, 7 dias após a sessão, os animais HAB apresentaram aumento da resposta emocional condicionada ao primeiro tom em comparação aos animais $\mathrm{NAB}\left({ }^{*} \mathrm{p}<0,05\right.$ obtido pelo teste ANOVA de uma via seguido pelo pós-teste de Duncan, $n=11-12 /$ grupo). Após 30 dias, a resposta de freezing foi espontaneamente recuperada nos animais $\mathrm{HAB}$ em comparação com os NAB $\left({ }^{*} \mathrm{p}<0,05\right.$ obtido 
pelo teste ANOVA de uma via seguido pelo pós-teste de Duncan, n=11-12/grupo). O tratamento com o CBD (15 e $30 \mathrm{mg} / \mathrm{kg}$ ) falhou em induzir quaisquer alterações nos animais HAB, uma vez que animais NAB foram expostos apenas ao tratamento com Veículo ( $\mathrm{p}>0,05$, obtido pelo teste ANOVA de uma via seguido pelo pós-teste de Duncan, $n=11-12$ grupo).

Considerando a falta de efeitos agudos do CBD em todos os testes utilizados, aliado à dificuldade em conseguir número suficiente desses animais para realização de mais experimentos comportamentais, decidimos investigar os efeitos do CBD em culturas primárias de micróglias e em um modelo animal de estresse preditivo para PTSD.

\subsection{Avaliação dos efeitos do Canabidiol sobre culturas primárias de micróglias estimuladas com LPS}

\subsubsection{Experimento 18:}

Como esperado, o estímulo com LPS (10 ng/ml) aumentou a expressão relativa de $I l l b$ (Fig. 22A), Tnfa (Fig. 22B) e Il6 (Fig. 22C) em culturas primárias de micróglias nos tempos 4 e 24 h. O efeito do LPS sobre a expressão gênica de TNF- $\alpha$ foi significantemente menor na estimulação de 24 h em comparação com 4 h (Fig. 22B). Já os efeitos sobre IL-1 $\beta$ (Fig. 22A) e IL-6 (Fig. 22C) foram semelhantes em ambos os tempos de estimulação. O tratamento com CBD $(10 \mu \mathrm{g} / \mathrm{ml})$ diminuiu significativamente os níveis de $I l l b$ e $I l 6$ tanto em 4 quanto em $24 \mathrm{~h}$ de estímulo; sem qualquer efeito sobre Tnfa - apesar de existir tendência gráfica clara $4 \mathrm{~h}$ após o LPS.

A.

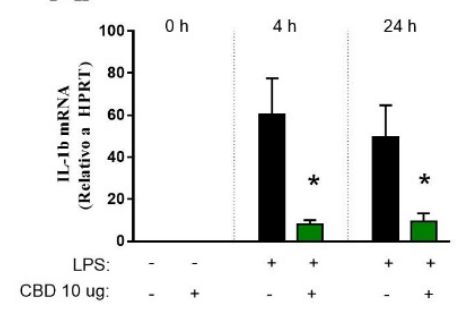

B.

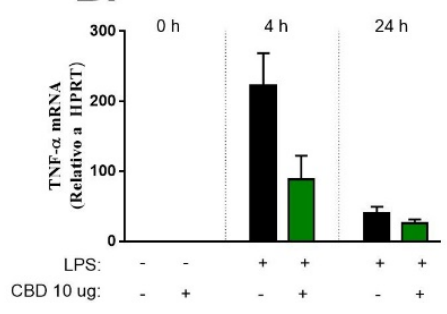

C.

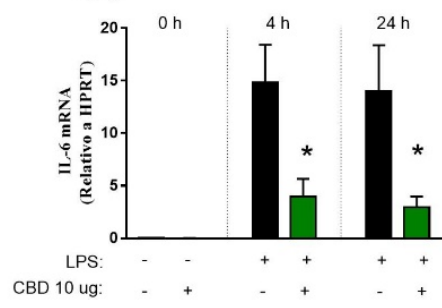


Fig. 24. LPS aumenta a expressão relativa dos genes de IL-1 $\beta$, TNF- $\alpha$ e IL-6 em cultura primária de micróglias. $\mathrm{O}$ tratamento celular com Canabidiol $(\mathrm{CBD} ; 10 \mu \mathrm{g})$ diminuiu os efeitos do LPS (10 ng/ml) sobre os níveis IL-1 $\beta$ e IL-6, mas não sobre TNF- $\alpha$. Dados apresentados como Média \pm E.P.M., $n=8-9$ /grupo. ${ }^{*} \mathrm{p}<0,05$ representa diferença entre os grupos CBD e LPS no tempo específico, obtido pelo teste ANOVA de uma via, seguido por post-hoc de Duncan.

\subsection{Efeitos do Canabidiol em camundongos submetidos a um protocolo de PTSD}

\subsubsection{Experimento 19:}

O modelo animal de PTSD, baseado em choques nas patas, aumentou o tempo de congelamento dos animais em ambos os contextos, cilindro (Fig. 25A) e caixa de condicionamento (Fig. 25D). Houve, ainda, diminuição da exploração vertical dos animais nos animais submetidos ao trauma em comparação com os não estressados, aqui representado como número de rearings, tanto no cilindro (Fig. 25B) quanto na caixa (25E). Não foram observadas diferenças no número de SAPs (Fig. 25C e 25F).

O tratamento repetido com o CBD em ambas as doses $(10$ e $30 \mathrm{mg} / \mathrm{kg})$ não reverteu os efeitos do estresse. 
Congelamento

A.

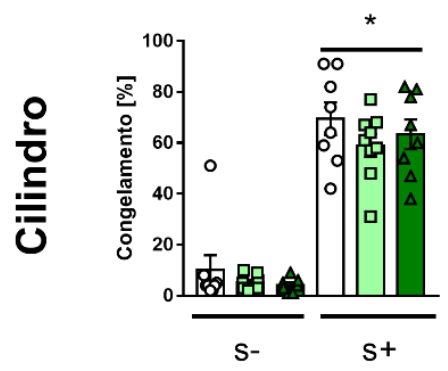

D.

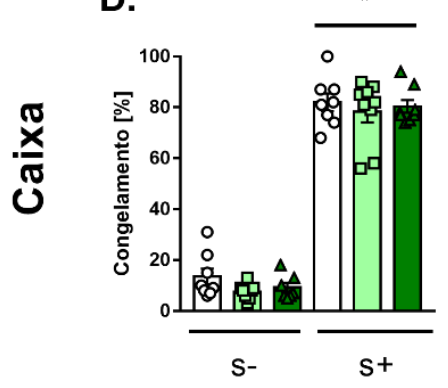

Rearing

B.

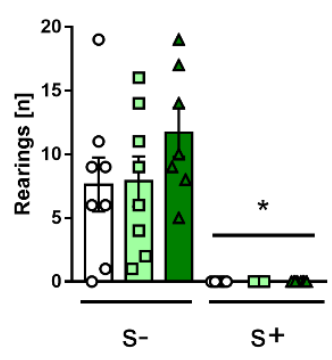

E.

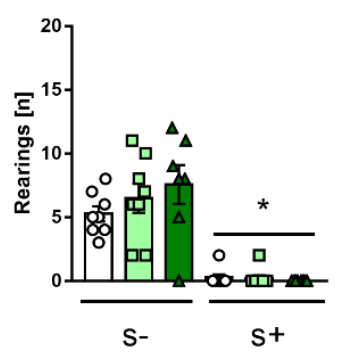

SAP

C.

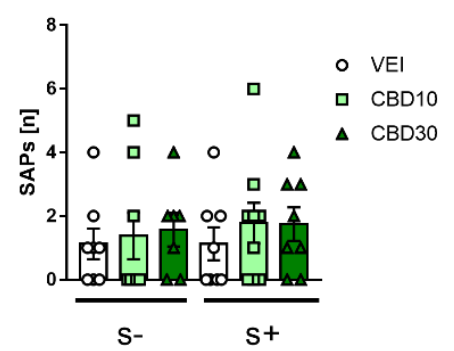

F.

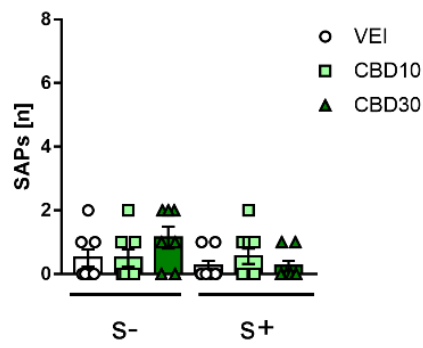

Fig. 25. Exposição repetida ao canabidiol não melhora o prejuízo comportamental induzido pelo modelo de PTSD baseado em choques nas patas. S- representa o grupo não estressado; S+ representa o grupo estressado. Dados apresentados como Média \pm E.P.M.; *p $<0,05$ em comparação com o grupo não estressado, obtido pelo teste Kruskal Wallis seguido por Dunn, $\mathrm{n}=$ 7-9/group.

Já no BMT, o estresse não alterou os parâmetros avaliados durante a habituação Rearings (Fig. 26A), SAPs (Fig. 26B) e latência para cruzar a arena (Fig. 26C) - e também durante o teste: Respostas passivas (Fig. 26D) e ativas (Fig. 26E), assim como o número de pulos espontâneos (Fig. 26F). 
A.

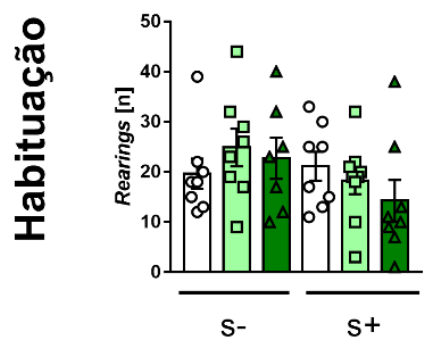

D.

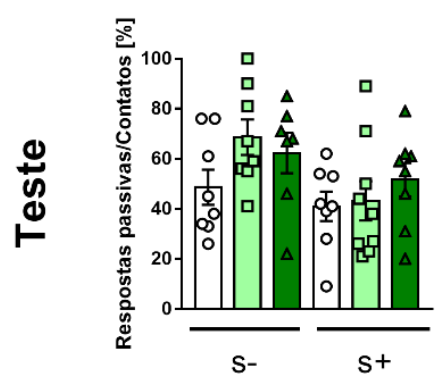

B.

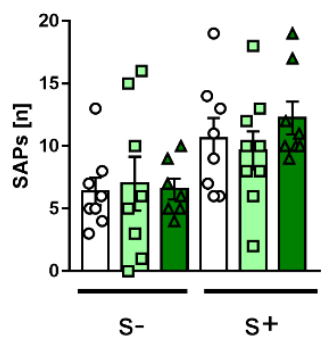

E.

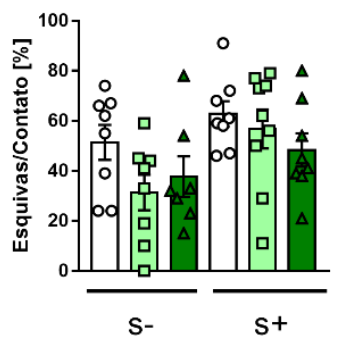

C.

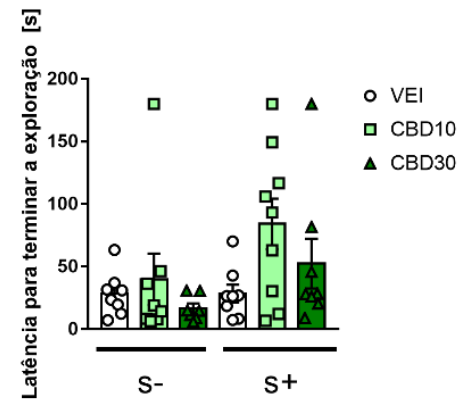

F.

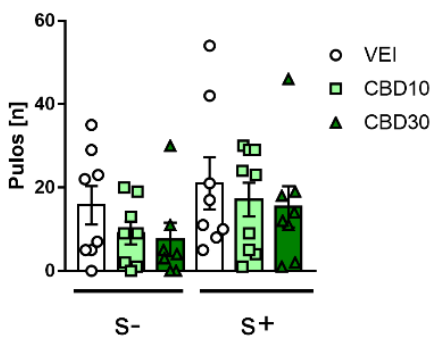

Fig. 26. Modelo de PTSD falha em induzir alterações comportamentais no teste de mania induzida pelo besouro. S- Representa o grupo não estressado; $\mathrm{S}+$ representa o grupo estressado. Dados apresentados como Média \pm E.P.M.; $p>0,05$ em comparação com o grupo não estressado, obtido pelo teste Kruskal Wallis seguido por Dunn, n=7-9/group.

O peso corporal dos animais foi avaliado a cada dois dias, a partir do primeiro dia de tratamento e não houve qualquer efeito do tratamento ou estresse prévio (dados não mostrados; $\mathrm{p}>0,05$ obtido por ANOVAr, $n=7-9 /$ grupo).

A ausência de efeito importante do CBD neste modelo foi confirmado em experimento paralelo, realizado em colaboração com a Dra. Amanda Sales no Brasil. Utilizando um protocolo experimental semelhante, verificamos que o estresse aumentou o tempo de congelamento dos animais reexpostos ao contexto no grupo veículo e CBD15, mas não no grupo CBD30, quando comparado ao grupo veículo não estressado (Fig. 27A). Embora este resultado possa sugerir um efeito anti-estresse, ele não foi observado no LCE. Neste teste, o estresse não alterou o tempo (Fig. 27B) e a frequência dos animais nos braços abertos (27C). Houve, inclusive, tendência do CBD $15 \mathrm{mg} / \mathrm{kg}$ em diminuir o tempo de permanência nos braços aberto, sugerindo um efeito tipoansiogênico da droga per se ( $\mathrm{p}=0,065$, ANOVA de uma via seguido por post-hoc de Duncan). 
A.

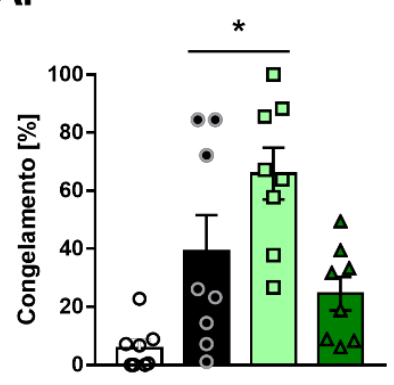

B.

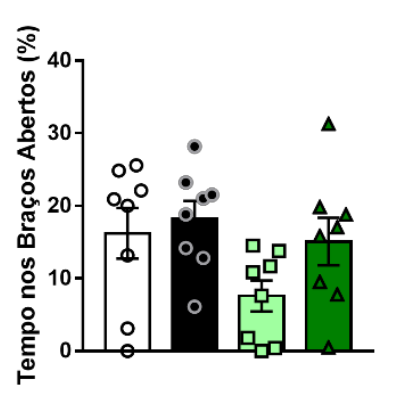

C.

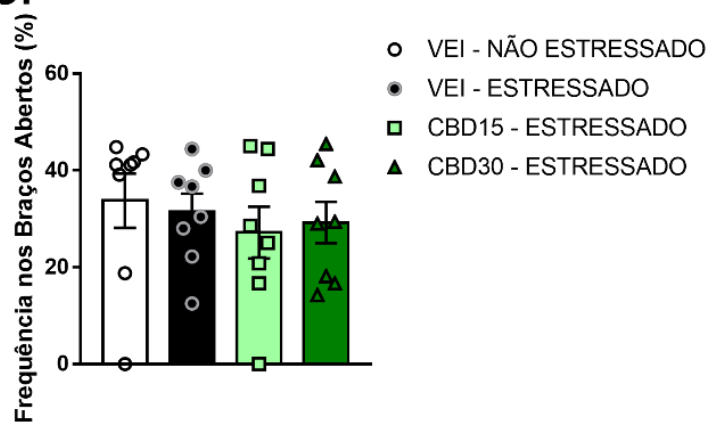

Fig. 27. Modelo de PTSD baseado em choques nas patas aumenta o tempo de congelamento dos animais, mas não altera parâmetros relacionados à ansiedade no teste do labirinto em cruz elevado. Dados apresentados como Média \pm E.P.M.; ${ }^{*} p<0,05$ em comparação com o grupo veículo - não estressado, obtido pelo teste Kruskal Wallis seguido por Dunn, n=7-8/group. Resultados do teste do labirinto em cruz elevado foram analisados pelo teste ANOVA de uma via seguido por post-hoc de Duncan. 
$\underline{\text { Discussão }}$ 


\section{DISCUSSÃO}

A exposição de animais experimentais a diferentes estressores induz alterações comportamentais, químicas e estruturais úteis para o estudo da neurobiologia de transtornos mentais (CAMPOS; FOGACA; AGUIAR; GUIMARAES, 2013). Modelos animais, portanto, são desenvolvidos com o objetivo de mimetizar uma doença ou condição médica humana, em animais de laboratório; e vêm sendo amplamente utilizados em estudos pré-clínicos na área de psiquiatria. Os critérios de validade são aspectos importantes para a avaliação de modelos animais que melhor representam determinadas psicopatologias. Nesse sentido, três critérios apresentam destaque no âmbito translacional: Validade de face ou aparente, que se refere à habilidade que o modelo animal tem em induzir, no animal, sintomas e/ou características comportamentais semelhantes aos observados na clínica. Em geral, é bastante limitada a alguns comportamentos, haja vista que muitos sintomas são definidos subjetivamente. Já a validade de construto, corresponde à capacidade do modelo em reproduzir mecanismos neurobiológicos e/ou fisiopatológicos da doença - por exemplo, desbalanço nos níveis de neurotransmissores ou envolvimento de determinados substratos ou regiões cerebrais. Por fim, a validade preditiva relaciona-se com a resposta dos animais, submetidos ao modelo, à terapia eficaz utilizada para a determinada condição médica em humanos (BAKER, 2011; CZEH; FUCHS; WIBORG; SIMON, 2016; SIEGMUND; WOTJAK, 2006). Diante disso, busca-se o desenvolvimento e utilização de modelos animais que consigam abranger ao máximo estes critérios de validade.

Nesse sentido, o estresse crônico imprevisível está dentre os modelos de depressão mais utilizados, baseado principalmente na imprevisibilidade das situações estressantes cotidianas, bem como na sua capacidade de induzir comportamentos tipo-anedônicos em animais, características bastante importantes dos transtornos depressivos em humanos. A anedonia é perda da capacidade de sentir prazer em situações que anteriormente eram ou normalmente são prazerosas. Esse modelo gera, ainda, outras alterações comportamentais, neuroquímicas, neuroimunes e neuroendocrinológicas de modo duradouro e semelhante ao observado na clínica. 
Além disso, algumas dessas alterações são revertidas pelo tratamento repetido, mas não agudo, com drogas antidepressivas e ansiolíticas (CRYAN; SLATTERY, 2007; CZEH; FUCHS; WIBORG; SIMON, 2016; SLATTERY; CRYAN, 2014).

De modo geral, na maioria dos experimentos, observamos que o protocolo de CUS utilizado no presente projeto causou uma diminuição de peso corporal dos animais, bem como alterações comportamentais compatíveis com trabalhos da literatura - aumento do tempo de imobilidade e hipolocomoção (FERNANDES; GUPTA, 2019). Entretanto, o protocolo de preferência pela sacarose, considerado padrão ouro para validação do modelo, forneceu resultados bastante inconsistentes. No que se refere às aparentes alterações na expressão gênica de componentes do inflamassoma de NLRP3, apesar de o número amostral ser bastante pequeno, os resultados sugerem uma regulação distinta da expressão gênica de NLRP3 e de caspase-1 no HIP e CPF, com provável aumento no primeiro e diminuição no segundo. Particularmente em relação ao CPF, eles estão em desacordo com resultados já descritos na literatura tanto em ratos (PAN; CHEN; ZHANG; KONG, 2014) quanto em camundongos submetidos ao CUS (SU; ZHANG; CHEN; GONG et al., 2017) ou a estresse crônico por restrição (ALCOCER-GOMEZ; ULECIAMORON; MARIN-AGUILAR; RYBKINA et al., 2016). Um fator que poderia explicar esta contradição seria a distância temporal entre o término do estresse e eutanásia do animal, uma vez que o RNAm já pode ter sido traduzido e as proteínas estarem funcionais. Para investigar essa hipótese, seria necessária a realização de experimentos para avaliar os níveis proteicos através de experimentos de Western Blotting (WB). Uma forma complementar ao WB para essa investigação e utilizada no presente trabalho, foi a dosagem de IL-1 $\beta$ circulante e nas regiões alvo no cérebro. Entretanto, novamente em desacordo com a literatura, nenhuma diferença foi encontrada (ALCOCER-GOMEZ; ULECIA-MORON; MARIN-AGUILAR; RYBKINA et al., 2016; GOSHEN; KREISEL; BEN-MENACHEM-ZIDON; LICHT et al., 2008; YOU; LUO; ZHANG; CHEN et al., 2011).

Diante da baixa reprodutibilidade dos resultados obtidos com o protocolo de CUS 
utilizado no presente trabalho, a avaliação dos efeitos do CBD sobre as alterações comportamentais e possíveis alterações moleculares, ficou comprometida.

O modelo único de estresse por restrição adotado posteriormente aos experimentos com CUS, é um dos modelos animais mais comumente empregado para induzir alterações comportamentais, bioquímicas e fisiológicas na experimentação animal. O estresse por restrição se baseia na premissa do estresse físico e psicológico inescapáveis e, após o término do protocolo, em geral os animais apresentam aumento nos níveis de comportamentos relacionados à ansiedade e, em menor proporção, depressão (CAMPOS; FOGACA; AGUIAR; GUIMARAES, 2013; CHU; ZHOU; HU; LOU et al., 2016; ZHANG; HU; LI; LI et al., 2019).

Nesse sentido, os resultados obtidos nos experimentos realizados estão de acordo com a literatura em ratos, uma vez que observamos que o estresse por restrição diminuiu a frequência dos animais nos braços abertos do LCE quando testados 24 h após o estresse (FOGACA; REIS; CAMPOS; GUIMARAES, 2014; GOMES; ALVES; GUIMARAES; CORREA et al., 2013; HARTMANN; LISBOA; SONEGO; COUTINHO et al., 2019; RESSTEL; TAVARES; LISBOA; JOCA et al., 2009). Em relação às respostas tardias ao estresse, sete dias após o protocolo de estresse, houve diminuição do tempo, mas não da frequência, de entradas nos braços abertos do LCE. A administração repetida de CBD $(30 \mathrm{mg} / \mathrm{kg})$ produziu tendência a um efeito tipoansiogênico em animais não estressados e tipo-ansiolítico em animais estressados. Efeito semelhante havia sido observado previamente pelo nosso grupo, em ratos submetidos ao estresse por restrição (2h). Nesse estudo, os microinjetados com o CBD (30 nmol) na região pré-límbica do CPF, 15 min antes da exposição ao LCE e 24 h após o estresse (FOGACA; REIS; CAMPOS; GUIMARAES, 2014). Apesar de diferença do protocolo e da linhagem animal utilizada em ambos os estudos, esses achados nos permitem sugerir que os efeitos do CBD podem ser duais e dependentes da condição prévia de estresse do animal.

O CBD utilizado neste projeto havia sido recentemente introduzido em nosso laboratório, por possuir maior pureza com relação às quantidades de THC, principal composto 
psicotomimético de Cannabis sativa; portanto, poderíamos ter diferenças farmacocinéticas e farmacodinâmicas consideráveis em relação aos estudos prévios realizados pelo nosso grupo (DEIANA; WATANABE; YAMASAKI; AMADA et al., 2012). Diante disso, decidimos testar a dose de $15 \mathrm{mg} / \mathrm{kg}$. Entretanto, conforme explicado anteriormente, por questões que envolveram a alteração da dieta fornecida pelos serviços do campus, que ocasionou um quadro de desnutrição crônica nos animais e alterou seus comportamentos (fato observado em todos os laboratórios que realizavam estudos comportamentais com roedores no período), o modelo animal parou de funcionar e os experimentos tiveram de ser interrompidos.

Nesse sentido, a dificuldade em estabelecer protocolos de estresse associado ao tempo avançado de doutorado, fez com que decidíssemos aplicar para a bolsa de Doutorado Sanduíche no Instituto Max-Planck de Psiquiatria para utilização de animais HAB e NAB.

Modelos animais baseados no acasalamento seletivo, são consideradas ferramentas experimentais importantes e interessantes, uma vez que a isogenicidade dos mesmos permite a investigação de mecanismos moleculares e genéticos associados especificamente às alterações comportamentais ou fisiológicas específicas apresentadas por esses animais. Em geral, considerase que esses modelos animais possuem validade de face e preditiva consideráveis, porém baixa validade de construto (CZEH; FUCHS; WIBORG; SIMON, 2016; OVERSTREET; WEGENER, 2013).

Em geral, os animais $\mathrm{HAB}$ apresentaram comportamentos relacionados à ansiedade em todos os testes utilizados, em conformidade com trabalhos prévios do grupo alemão (FILIOU; WEBHOFER; GORMANNS; ZHANG et al., 2012; FILIOU; ZHANG; TEPLYTSKA; RECKOW et al., 2011; HEINZ; GENEWSKY; WOTJAK, 2017; KROMER; KESSLER; MILFAY; BIRG et al., 2005; LANDGRAF; KESSLER; BUNCK; MURGATROYD et al., 2007; NUSSBAUMER; ASARA; TEPLYTSKA; MURPHY et al., 2016; YEN; ANDERZHANOVA; BUNCK; SCHULLER et al., 2013; YEN; MAUCH; DAHLHOFF; MICALE et al., 2012). Entretanto, o CBD não induziu os seus efeitos tipo-ansiolíticos amplamente descritos neste 
modelo psicopatológico de ansiedade. É importante considerar, contudo, que esses animais usualmente respondem apenas ao tratamento crônico com fluoxetina, mas não a outras drogas ansiolíticas ou antidepressivas, quando testados no LCE (dados não publicados) e em testes preditivos para transtornos depressivos (SAH; SCHMUCKERMAIR; SARTORI; GABURRO et al., 2012; SCHAUFLER; RONOVSKY; SAVALLI; CABATIC et al., 2016).

Dentre as poucas drogas capazes de induzir efeitos agudos nos animais HAB, existem relatos de que um agonista parcial de receptores benzodiazepínicos, assim como corticosterona, atenuam a resposta de medo condicionado ao som neste modelo (SARTORI; HAUSCHILD; BUNCK; GABURRO et al., 2011). Ainda nesse sentido, um estudo prévio do grupo alemão evidenciou que a administração aguda de URB597, um inibidor da FAAH, induz comportamento panicolítico e tipo-ansiolítico em animais HAB expostos ao BMT (HEINZ; GENEWSKY; WOTJAK, 2017). Sabe-se que o CBD também inibe a enzima FAAH, mecanismo pelo qual o CBD poderia induzir seus efeitos via ativação de receptores CB1 e CB2 (BISOGNO; HANUS; DE PETROCELLIS; TCHILIBON et al., 2001). Portanto, diante da dificuldade em obter número adequado de animais para os experimentos comportamentais, e a ausência de efeitos robustos do tratamento agudo com o CBD, optamos por interromper a utilização essa linhagem.

Outras trabalhos da literatura apoiam nossos resultados em relação aos efeitos antiinflamatórios in vitro do CBD sobre a cultura primária de micróglias estimuladas com LPS (BURSTEIN, 2015; DOS-SANTOS-PEREIRA; DA-SILVA; GUIMARAES; DEL-BEL, 2016; SONEGO; PRADO; VALE; SEPULVEDA-DIAZ et al., 2018). Apesar de a relação entre o mecanismo anti-inflamatório do CBD e o inflamassoma de NLRP3 ainda não terem sido investigadas em células da micróglia, este envolvimento já foi descrito para monócitos THP-1 (LIU; MA; SLITT; SEERAM, 2020) e em células-tronco mesenquimais gengivais. Estas últimas são células tronco com alta capacidade de diferenciação e, portanto, com amplo potencial terapêutico para tratamento de diversas condições médicas grave que dependem de transplante. Nesse sentido, os autores sugerem que o pré-tratamento dessas células com o CBD pode auxiliar 
na diminuição da rejeição do sistema imunológico aos transplantes, haja vista o efeito do CBD em diminuir a expressão de moléculas de superfície e citocinas inflamatórias importantes para rejeição destas células pelo sistema imunológico do transplantado (LIBRO; SCIONTI; DIOMEDE; MARCHISIO et al., 2016). Além disso, recentemente, foi descrito que o CBD de regula e contrapõe os efeitos do LPS em miRNA de células microgliais (BV-2) estimuladas com LPS de modo mais efetivo que o THC (JUKNAT; GAO; COPPOLA; VOGEL et al., 2019). Finalmente, os efeitos anti-inflamatórios do CBD sobre células da micróglia não se limitam apenas a estudos in vitro, uma vez que já foi descrito que diminuiu a ativação destas células em modelos animais de transtornos mentais (GOMES; LLORENTE; DEL BEL; VIVEROS et al., 2015; SONEGO; PRADO; VALE; SEPULVEDA-DIAZ et al., 2018).

Com estes resultados obtidos in vitro, indicando que a amostra de CBD utilizada na Alemanha era biologicamente ativa, resolvemos empregá-lo em outro protocolo experimental associado ao PTSD que havia sido desenvolvido pelo grupo Alemão. Este modelo tem como vantagem a dissociação entre componentes associativos e não-associativos das respostas de medo. Nesse sentido, as respostas associativas são relacionadas às características que remetem ao trauma; como por exemplo, a reexposição do animal à caixa em que houve a deflagração do choque. Já a resposta não-associativa se refere à sensibilidade fisiológica e/ou comportamental a estímulos potencialmente ameaçadores ou perigosos, como por exemplo a exposição de um tom em um novo ambiente - refletindo as características de hiperexcitação e apreensão frequentemente observadas em quadros de PTSD (SIEGMUND; WOTJAK, 2006; 2007a; b). O choque nas patas, por conta da falta de controle e imprevisibilidade aos animais, induz alterações comportamentais duradouras (DESLAURIERS; TOTH; DER-AVAKIAN; RISBROUGH, 2018; FLANDREAU; TOTH, 2018 ; SIEGMUND; WOTJAK, 2006; ZHANG; HU; LI; LI et al., 2019). Além disso, a habituação a este estressor é menor em comparação a outros estressores, como o estresse por restrição, por exemplo (FLANDREAU; TOTH, 2018). A grande vantagem desse protocolo, segundo alguns autores, seria a capacidade de controle das características do estresse por parte do experimentador 
(intensidade, duração, garantia, pistas ambientais, dentre outras). Além do período necessário para aparecimento e instalação do quadro, uma vez que para o transtorno em humanos é necessário um período de 'incubação'. Já a desvantagem é a menor variabilidade em termos de sensibilidade e resiliência, em comparação com humanos, uma vez que a maioria dos animais expostos ao estresse apresentariam alguma alteração duradoura. (BALI; JAGGI, 2015; FLANDREAU; TOTH, 2018). Discussões acerca do choque nas patas ser um trauma ou apenas um protocolo de medo, a depender da intensidade, número e duração do choque, também são exploradas na literatura (FLANDREAU; TOTH, 2018).

Devido às características e sintomas multifatoriais do PTSD, uma vez que envolve parâmetros e processos cardiovasculares/autonômicos, de memória, hiperexcitação e sensibilização ao estresse, alterações relacionadas ao sono, dentre outros; modelos animais com abrangência de todos os fatores ainda são escassos - de modo que normalmente alguns modelos envolvem características mais relacionadas a um grupo de sintomas do que outros.

No presente projeto, o protocolo de PTSD baseado em choques nas patas induziu aumento no tempo de congelamento, bem como generalização; conforme estudos prévios do grupo de pesquisa na Alemanha já haviam demonstrado (KAO; ANDERZHANOVA; ASARA; WOTJAK et al., 2015; KAO; HE; HENES; ASARA et al., 2016; KAO; HE; ZANNAS; HAHN et al., 2016; SIEGMUND; WOTJAK, 2007a; b). Essa observação, em especial, demonstra a validade de face do modelo, uma vez que este é um sintoma bastante característico na clínica (APA,2013).

Entretanto, diversos trabalhos prévios do grupo (não publicados), evidenciam que esse protocolo diminui a exploração dos animais estressados durante a fase de habituação no BMT; além de aumentar o número de respostas defensivas ativas. Dentre as possibilidades para explicar essa possível ausência de efeito, sugerimos que a injeção repetida por via intraperitoneal, associada ao manuseamento diário dos animais, esteja contribuindo para essa perda de efeito, uma vez que o BMT é um teste sensível ao manuseio de animais. Vale a pena ressaltar que foi a primeira vez, desde a padronização do modelo, que animais submetidos a protocolo de tratamento 
repetido foram testados.

Embora existam resultados positivos após administração repetida (CAMPOS; FERREIRA; GUIMARAES, 2012; FOGACA; CAMPOS; COELHO; DUMAN et al., 2018; MASATAKA, 2019), os efeitos tipo-ansiolíticos do CBD descritos em humanos (BERGAMASCHI; QUEIROZ; CHAGAS; DE OLIVEIRA et al., 2011; CRIPPA; DERENUSSON; FERRARI; WICHERT-ANA et al., 2011) e roedores (CASAROTTO; GOMES; RESSTEL; GUIMARAES, 2010; GUIMARAES; CHIARETTI; GRAEFF; ZUARDI, 1990; MOREIRA; AGUIAR; GUIMARAES, 2006; RESSTEL; JOCA; MOREIRA; CORREA et al., 2006; RESSTEL; TAVARES; LISBOA; JOCA et al., 2009) foram observados após a administração aguda. Além disso, resultados negativos e até mesmo opostos também são descritos na literatura (ELBATSH; ASSAREH; MARSDEN; KENDALL, 2012). As razões para essas diferenças não são claras, mas podem envolver diferentes protocolos e espécies utilizadas, além da provável possibilidade de que o CBD não age simplesmente como uma droga ansiolítica convencional, como benzodiazepínicos, por exemplo. Portanto, mais estudos comparativos investigando os efeitos e prováveis mecanismos do CBD em diferentes modelos de estresse e ansiedade são necessários para a compreensão de seu papel na terapêutica.

Neste sentido, os resultados do presente estudo trazem uma contribuição ao sugerirem que, em relação ao PTSD, o tratamento crônico tardio em relação ao trauma inicial com o CBD seria menos efetivo para reverter o quadro sintomatológico. Dados pré-clínicos, no entanto, sugerem que, se o tratamento for iniciado logo após a exposição ao evento traumático, este fitocanabinoide pode ser efetivo. Por exemplo, trabalhos prévios de nosso grupo evidenciaram que a exposição do rato ao gato induz respostas tipo-ansiogênicas e que estes efeitos são prevenidos pelo tratamento repetido com o CBD (CAMPOS; FERREIRA; GUIMARAES, 2012). Além disso, recentemente, observamos que o tratamento repetido com o CBD (5 mg/kg; 7 dias) preveniu as consequências comportamentais do estresse único prolongado (SPS) sobre processos de memória, em ratos testados após 8 dias da exposição aos estressores. Nesse sentido, este fitocanabinoide 
não foi capaz de facilitar a aquisição da extinção de modo significativo, porém preveniu prejuízos nos processos de retenção da memória de extinção induzidos pelo SPS. O tratamento agudo com o CBD, em uma dose 6 vezes maior que a utilizada no tratamento repetido (30 mg/kg), quando administrada 2-3 h após o término do estresse, preveniu os prejuízos do estresse sobre a extinção e a consolidação da memória de extinção.

Entretanto, quando houve a exposição dos animais a um novo estressor, uma espécie de lembrete de estresse (reminder), ao contrário do observado nos experimentos sem o reminder, o CBD (5 mg/kg; 7 dias) facilitou ambos os processos - aquisição e consolidação/retenção da extinção (dados não publicado).

Trabalhos prévios também reforçam essa influência do CBD sobre as diferentes fases do processamento de memórias aversivas. A administração de CBD antes da aquisição da memória aversiva (LEVIN; ALMEIDA; PERES; CALZAVARA et al., 2012) ou da reexposição ao contexto (recuperação/reativação) é capaz de atenuar as respostas emocionais condicionadas em ratos (LEMOS; RESSTEL; GUIMARAES, 2010; RESSTEL; JOCA; MOREIRA; CORREA et al., 2006). Com relação a extinção de memórias aversivas, Bitencourt e colaboradores evidenciaram que a administração intracerebroventricular de canabidiol facilita este processo em ratos (BITENCOURT; PAMPLONA; TAKAHASHI, 2008). Este efeito não foi observado em camundongos HAB submetidos ao protocolo de extinção no presente trabalho.

Finalmente, um conjunto importante de estudos com roedores sugere que o CBD possa afetar a reconsolidação de memórias aversivas (STERN; GAZARINI; TAKAHASHI; GUIMARAES et al., 2012; STERN; GAZARINI; VANVOSSEN; ZUARDI et al., 2015; STERN; DA SILVA; RAYMUNDI; DE SOUZA et al., 2017). O canabidiol, no protocolo testado, impediu a reconsolidação de memórias aversivas 1 e 7 dias após o protocolo de condicionamento. Esse efeito é dependente da administração do fitocanabinoide imediatamente após a sessão de recuperação e dura, ao menos, três semanas - uma vez que os animais não apresentaram recuperação espontânea (STERN; GAZARINI; TAKAHASHI; GUIMARAES et al., 2012). 
Apesar de, no presente trabalho, utilizarmos um protocolo experimental diferente do empregado nos trabalhos acima discutidos, a reativação da memória aversiva ou a exposição a um reminder de estresse poderiam fornecer resultados interessantes do ponto de vista de ação do CBD; uma vez que esta droga poderia gerar um eventual efeito através de processos relacionados à reconsolidação da memória aversiva. Esta é uma outra possibilidade a ser explorado no futuro e que, se confirmada, possui grande potencial de impacto translacional. 
$\underline{\text { Conclusão }}$ 


\section{CONCLUSÃO}

Infelizmente, por inúmeras situações que fugiram de nosso controle e foram aqui esclarecidas, parte dos objetivos inicialmente propostos não conseguiram ser investigados.

Os protocolos do CUS empregados produziram alterações comportamentais, porém com baixa replicabilidade, dificultando a análise molecular e a investigação de um possível efeito do CBD.

O protocolo de estresse único por restrição induziu alterações comportamentais bastante interessantes, porém com a perda de efeito do protocolo, por razões previamente explicadas, tivemos de interromper os experimentos.

Os animais $\mathrm{HAB}$ apresentaram comportamentos relacionados à ansiedade em comparação com os animais NAB, conforme previamente descrito. Este efeito, no entanto, não foi afetado pelo tratamento agudo com o CBD (15 e $30 \mathrm{mg} / \mathrm{kg})$.

Os efeitos do CBD em células da micróglia estimuladas com LPS estão de acordo com a literatura e nos permitem sugerir o envolvimento da plataforma de NLRP3. Entretanto, para comprovação desse efeito, mais estudos devem ser feitos.

O modelo de PTSD utilizado no presente projeto induziu alterações comportamentais em camundongos C57BL/6 testados para generalização e expressão de respostas de medo, mas não no BMT. O tratamento repetido com o CBD (10 e $30 \mathrm{mg} / \mathrm{kg})$ não melhorou esse prejuízo comportamental induzido pelo choque nas patas.

No conjunto, os resultados indicam que os efeitos ansiolíticos agudos do CBD, já amplamente descritos na literatura, necessitam de melhor caracterização após tratamento prolongado, investigando-se, entre outros aspectos, a resposta em diferentes modelos e regimes de administração. Em relação a estes últimos, nosso trabalho sugere que o tratamento crônico 
tardio com o CBD em relação a um trauma inicial que pode levar ao desenvolvimento de PTSD seria pouco efetivo para reverter o quadro sintomatológico. 
Referências Bibliográficas 


\section{REFERÊNCIAS BIBLIOGRÁFICAS}

ACHESON, D. T.; FORSYTH, J. P.; MOSES, E. Interoceptive fear conditioning and panic disorder: the role of conditioned stimulus-unconditioned stimulus predictability. Behav Ther, 43, n. 1, p. 174-189, Mar 2012.

ADER, R.; COHEN, N. Psychoneuroimmunology: conditioning and stress. Annu Rev Psychol, 44, p. 53-85, 1993.

AGUADO, T.; MONORY, K.; PALAZUELOS, J.; STELLA, N. et al. The endocannabinoid system drives neural progenitor proliferation. FASEB J, 19, n. 12, p. 1704-1706, Oct 2005.

AHRENS, J.; DEMIR, R.; LEUWER, M.; DE LA ROCHE, J. et al. The nonpsychotropic cannabinoid cannabidiol modulates and directly activates alpha-1 and alpha-1-Beta glycine receptor function. Pharmacology, 83, n. 4, p. 217-222, 2009.

ALBORNOZ, E. A.; WOODRUFF, T. M.; GORDON, R. Inflammasomes in CNS Diseases. Exp Suppl, 108, p. 41-60, 2018.

ALCOCER-GOMEZ, E.; DE MIGUEL, M.; CASAS-BARQUERO, N.; NUNEZ-VASCO, J. et al. NLRP3 inflammasome is activated in mononuclear blood cells from patients with major depressive disorder. Brain Behav Immun, 36, p. 111-117, Feb 2014.

ALCOCER-GOMEZ, E.; ULECIA-MORON, C.; MARIN-AGUILAR, F.; RYBKINA, T. et al. Stress-Induced Depressive Behaviors Require a Functional NLRP3 Inflammasome. Mol Neurobiol, 53, n. 7, p. 4874-4882, Sep 2016.

AMSTERDAM, A.; SASSON, R. The anti-inflammatory action of glucocorticoids is mediated by cell type specific regulation of apoptosis. Mol Cell Endocrinol, 189, n. 1-2, p. 1-9, Mar 28 2002.

ANISMAN, H.; RAVINDRAN, A. V.; GRIFFITHS, J.; MERALI, Z. Endocrine and cytokine correlates of major depression and dysthymia with typical or atypical features. Mol Psychiatry, 4, n. 2, p. 182-188, Mar 1999.

ARONSSON, M.; FUXE, K.; DONG, Y.; AGNATI, L. F. et al. Localization of glucocorticoid receptor mRNA in the male rat brain by in situ hybridization. Proc Natl Acad Sci U S A, 85, n. 23, p. 9331-9335, Dec 1988.

ATHMAN, R.; PHILPOTT, D. Innate immunity via Toll-like receptors and Nod proteins. Curr Opin Microbiol, 7, n. 1, p. 25-32, Feb 2004. 
AUPPERLE, R. L.; MELROSE, A. J.; STEIN, M. B.; PAULUS, M. P. Executive function and PTSD: disengaging from trauma. Neuropharmacology, 62, n. 2, p. 686-694, Feb 2012.

BABELOVA, A.; MORETH, K.; TSALASTRA-GREUL, W.; ZENG-BROUWERS, J. et al. Biglycan, a danger signal that activates the NLRP3 inflammasome via toll-like and P2X receptors. J Biol Chem, 284, n. 36, p. 24035-24048, Sep 42009.

BAIN, D. L.; YANG, Q.; CONNAGHAN, K. D.; ROBBLEE, J. P. et al. Glucocorticoid receptorDNA interactions: binding energetics are the primary determinant of sequence-specific transcriptional activity. J Mol Biol, 422, n. 1, p. 18-32, Sep 72012.

BAKER, D. G.; WEST, S. A.; NICHOLSON, W. E.; EKHATOR, N. N. et al. Serial CSF corticotropin-releasing hormone levels and adrenocortical activity in combat veterans with posttraumatic stress disorder. Am J Psychiatry, 156, n. 4, p. 585-588, Apr 1999.

BAKER, M. Animal models: inside the minds of mice and men. Nature, 475, n. 7354, p. $123-$ 128, Jul 62011.

BALI, A.; JAGGI, A. S. Electric foot shock stress adaptation: Does it exist or not? Life Sci, 130, p. 97-102, Jun 12015.

BARICHELlO, T.; CERETTA, R. A.; GENEROSO, J. S.; MOREIRA, A. P. et al. Cannabidiol reduces host immune response and prevents cognitive impairments in Wistar rats submitted to pneumococcal meningitis. Eur J Pharmacol, 697, n. 1-3, p. 158-164, Dec 152012.

BERGAMASCHI, M. M.; QUEIROZ, R. H.; CHAGAS, M. H.; DE OLIVEIRA, D. C. et al. Cannabidiol reduces the anxiety induced by simulated public speaking in treatment-naive social phobia patients. Neuropsychopharmacology, 36, n. 6, p. 1219-1226, May 2011.

BIERHAUS, A.; WOLF, J.; ANDRASSY, M.; ROHLEDER, N. et al. A mechanism converting psychosocial stress into mononuclear cell activation. Proc Natl Acad Sci U S A, 100, n. 4, p. 1920-1925, Feb 182003.

BISOGNO, T.; HANUS, L.; DE PETROCELLIS, L.; TCHILIBON, S. et al. Molecular targets for cannabidiol and its synthetic analogues: effect on vanilloid VR1 receptors and on the cellular uptake and enzymatic hydrolysis of anandamide. Br J Pharmacol, 134, n. 4, p. 845-852, Oct 2001.

BITENCOURT, R. M.; PAMPLONA, F. A.; TAKAHASHI, R. N. Facilitation of contextual fear memory extinction and anti-anxiogenic effects of AM404 and cannabidiol in conditioned rats. Eur Neuropsychopharmacol, 18, n. 12, p. 849-859, Dec 2008.

BLANCHARD, D. C.; BLANCHARD, R. J.; GRIEBEL, G. Defensive responses to predator threat in the rat and mouse. Curr Protoc Neurosci, Chapter 8, p. Unit 8 19, Feb 2005. 
BLANCHARD, R. J.; BLANCHARD, D. C. Attack and defense in rodents as ethoexperimental models for the study of emotion. Prog Neuropsychopharmacol Biol Psychiatry, 13 Suppl, p. S3-14, 1989.

BORRELli, F.; AVIELLO, G.; ROMANO, B.; ORLANDO, P. et al. Cannabidiol, a safe and non-psychotropic ingredient of the marijuana plant Cannabis sativa, is protective in a murine model of colitis. J Mol Med (Berl), 87, n. 11, p. 1111-1121, Nov 2009.

BREEN, M. S.; TYLEE, D. S.; MAIHOFER, A. X.; NEYLAN, T. C. et al. PTSD Blood Transcriptome Mega-Analysis: Shared Inflammatory Pathways across Biological Sex and Modes of Trauma. Neuropsychopharmacology, 43, n. 3, p. 469-481, Feb 2018.

BREMNER, J. D.; LICINIO, J.; DARNELL, A.; KRYSTAL, J. H. et al. Elevated CSF corticotropin-releasing factor concentrations in posttraumatic stress disorder. Am J Psychiatry, 154, n. 5, p. 624-629, May 1997.

BURSTEIN, S. Cannabidiol (CBD) and its analogs: a review of their effects on inflammation. Bioorg Med Chem, 23, n. 7, p. 1377-1385, Apr 12015.

BUSILLO, J. M.; AZZAM, K. M.; CIDLOWSKI, J. A. Glucocorticoids sensitize the innate immune system through regulation of the NLRP3 inflammasome. J Biol Chem, 286, n. 44, p. 38703-38713, Nov 42011.

CAIN, D. W.; CIDLOWSKI, J. A. Immune regulation by glucocorticoids. Nat Rev Immunol, 17, n. 4, p. 233-247, Apr 2017.

CALABRESE, E. J. Stress biology and hormesis: the Yerkes-Dodson law in psychology--a special case of the hormesis dose response. Crit Rev Toxicol, 38, n. 5, p. 453-462, 2008.

CALCIA, M. A.; BONSALL, D. R.; BLOOMFIELD, P. S.; SELVARAJ, S. et al. Stress and neuroinflammation: a systematic review of the effects of stress on microglia and the implications for mental illness. Psychopharmacology (Berl), 233, n. 9, p. 1637-1650, May 2016.

CAMPOS, A. C.; BRANT, F.; MIRANDA, A. S.; MACHADO, F. S. et al. Cannabidiol increases survival and promotes rescue of cognitive function in a murine model of cerebral malaria. Neuroscience, 289, p. 166-180, Mar 192015.

CAMPOS, A. C.; FERREIRA, F. R.; GUIMARAES, F. S. Cannabidiol blocks long-lasting behavioral consequences of predator threat stress: possible involvement of 5HT1A receptors. $\mathbf{J}$ Psychiatr Res, 46, n. 11, p. 1501-1510, Nov 2012.

CAMPOS, A. C.; FOGACA, M. V.; AGUIAR, D. C.; GUIMARAES, F. S. Animal models of anxiety disorders and stress. Braz J Psychiatry, 35 Suppl 2, p. S101-111, 2013. 
CAMPOS, A. C.; GUIMARAES, F. S. Involvement of 5HT1A receptors in the anxiolytic-like effects of cannabidiol injected into the dorsolateral periaqueductal gray of rats. Psychopharmacology (Berl), 199, n. 2, p. 223-230, Aug 2008.

CAMPOS, A. C.; GUIMARAES, F. S. Evidence for a potential role for TRPV1 receptors in the dorsolateral periaqueductal gray in the attenuation of the anxiolytic effects of cannabinoids. Prog Neuropsychopharmacol Biol Psychiatry, 33, n. 8, p. 1517-1521, Nov 132009.

CAMPOS, A. C.; MOREIRA, F. A.; GOMES, F. V.; DEL BEL, E. A. et al. Multiple mechanisms involved in the large-spectrum therapeutic potential of cannabidiol in psychiatric disorders. Philos Trans R Soc Lond B Biol Sci, 367, n. 1607, p. 3364-3378, Dec 52012.

CAMPOS, A. C.; ORTEGA, Z.; PALAZUELOS, J.; FOGACA, M. V. et al. The anxiolytic effect of cannabidiol on chronically stressed mice depends on hippocampal neurogenesis: involvement of the endocannabinoid system. Int J Neuropsychopharmacol, 16, n. 6, p. 1407-1419, Jul 2013.

CANNON, W. A. On the Variation of the Oxygen Content of Cultural Solutions. Science, 75, n. 1934, p. 108-109, Jan 221932.

CANTERAS, N. S.; RESSTEL, L. B.; BERTOGLiO, L. J.; CAROBREZ ADE, P. et al. Neuroanatomy of anxiety. Curr Top Behav Neurosci, 2, p. 77-96, 2010.

CASAROTTO, P. C.; GOMES, F. V.; RESSTEL, L. B.; GUIMARAES, F. S. Cannabidiol inhibitory effect on marble-burying behaviour: involvement of CB1 receptors. Behav Pharmacol, 21, n. 4, p. 353-358, Jul 2010.

CASTANON, N.; BLUTHE, R. M.; DANTZER, R. Chronic treatment with the atypical antidepressant tianeptine attenuates sickness behavior induced by peripheral but not central lipopolysaccharide and interleukin-1beta in the rat. Psychopharmacology (Berl), 154, n. 1, p. 50-60, Feb 2001.

CHABY, L. E.; SHERIFF, M. J.; HIRRLINGER, A. M.; BRAITHWAITE, V. A. Can we understand how developmental stress enhances performance under future threat with the YerkesDodson law? Commun Integr Biol, 8, n. 3, p. e1029689, May-Jun 2015.

CHEN, J.; WANG, Z. Z.; ZHANG, S.; ZUO, W. et al. Does mineralocorticoid receptor play a vital role in the development of depressive disorder? Life Sci, 152, p. 76-81, May 12016.

CHU, X.; ZHOU, Y.; HU, Z.; LOU, J. et al. 24-hour-restraint stress induces long-term depressivelike phenotypes in mice. Sci Rep, 6, p. 32935, Sep 92016. 
COSTELLO, H.; GOULD, R. L.; ABROL, E.; HOWARD, R. Systematic review and metaanalysis of the association between peripheral inflammatory cytokines and generalised anxiety disorder. BMJ Open, 9, n. 7, p. e027925, Jul 192019.

COUTINHO, A. E.; CHAPMAN, K. E. The anti-inflammatory and immunosuppressive effects of glucocorticoids, recent developments and mechanistic insights. Mol Cell Endocrinol, 335, n. 1, p. 2-13, Mar 152011.

CRAIN, J. M.; NIKODEMOVA, M.; WATTERS, J. J. Microglia express distinct M1 and M2 phenotypic markers in the postnatal and adult central nervous system in male and female mice. $\mathbf{J}$ Neurosci Res, 91, n. 9, p. 1143-1151, Sep 2013.

CRIPPA, J. A.; DERENUSSON, G. N.; FERRARI, T. B.; WICHERT-ANA, L. et al. Neural basis of anxiolytic effects of cannabidiol (CBD) in generalized social anxiety disorder: a preliminary report. J Psychopharmacol, 25, n. 1, p. 121-130, Jan 2011.

CRYAN, J. F.; SLATTERY, D. A. Animal models of mood disorders: Recent developments. Curr Opin Psychiatry, 20, n. 1, p. 1-7, Jan 2007.

CZEH, B.; FUCHS, E.; WIBORG, O.; SIMON, M. Animal models of major depression and their clinical implications. Prog Neuropsychopharmacol Biol Psychiatry, 64, p. 293-310, Jan 4 2016.

DANTZER, R. Cytokine-induced sickness behavior: mechanisms and implications. Ann N Y Acad Sci, 933, p. 222-234, Mar 2001a.

DANTZER, R. Cytokine-induced sickness behavior: where do we stand? Brain Behav Immun, 15, n. 1, p. 7-24, Mar 2001b.

DASKALAKIS, N. P.; COHEN, H.; NIEVERGELT, C. M.; BAKER, D. G. et al. New translational perspectives for blood-based biomarkers of PTSD: From glucocorticoid to immune mediators of stress susceptibility. Exp Neurol, 284, n. Pt B, p. 133-140, Oct 2016.

DAVALOS, D.; GRUTZENDLER, J.; YANG, G.; KIM, J. V. et al. ATP mediates rapid microglial response to local brain injury in vivo. Nat Neurosci, 8, n. 6, p. 752-758, Jun 2005.

DE BOSSCHER, K.; VANDEN BERGHE, W.; HAEGEMAN, G. The interplay between the glucocorticoid receptor and nuclear factor-kappaB or activator protein-1: molecular mechanisms for gene repression. Endocr Rev, 24, n. 4, p. 488-522, Aug 2003.

DE KLOET, E. R.; JOELS, M.; HOLSBOER, F. Stress and the brain: from adaptation to disease. Nat Rev Neurosci, 6, n. 6, p. 463-475, Jun 2005. 
DE KLOET, E. R.; OITZL, M. S.; JOELS, M. Stress and cognition: are corticosteroids good or bad guys? Trends Neurosci, 22, n. 10, p. 422-426, Oct 1999.

DEIANA, S.; WATANABE, A.; YAMASAKI, Y.; AMADA, N. et al. Plasma and brain pharmacokinetic profile of cannabidiol (CBD), cannabidivarine (CBDV), Delta(9)tetrahydrocannabivarin (THCV) and cannabigerol (CBG) in rats and mice following oral and intraperitoneal administration and $\mathrm{CBD}$ action on obsessive-compulsive behaviour. Psychopharmacology (Berl), 219, n. 3, p. 859-873, Feb 2012.

DEJEAN, C.; RICHARD, D. [Mechanisms of action of glucocorticoids]. Rev Med Interne, 34, n. 5, p. 264-268, May 2013.

DELGADO, P. L. Depression: the case for a monoamine deficiency. J Clin Psychiatry, 61 Suppl 6, p. 7-11, 2000.

DESLAURIERS, J.; TOTH, M.; DER-AVAKIAN, A.; RISBROUGH, V. B. Current Status of Animal Models of Posttraumatic Stress Disorder: Behavioral and Biological Phenotypes, and Future Challenges in Improving Translation. Biol Psychiatry, 83, n. 10, p. 895-907, May 15 2018.

DIORIO, D.; VIAU, V.; MEANEY, M. J. The role of the medial prefrontal cortex (cingulate gyrus) in the regulation of hypothalamic-pituitary-adrenal responses to stress. J Neurosci, 13, n. 9, p. 3839-3847, Sep 1993.

DOS-SANTOS-PEREIRA, M.; DA-SILVA, C. A.; GUIMARAES, F. S.; DEL-BEL, E. Coadministration of cannabidiol and capsazepine reduces L-DOPA-induced dyskinesia in mice: Possible mechanism of action. Neurobiol Dis, 94, p. 179-195, Oct 2016.

DOWLATI, Y.; HERRMANN, N.; SWARDFAGER, W.; LIU, H. et al. A meta-analysis of cytokines in major depression. Biol Psychiatry, 67, n. 5, p. 446-457, Mar 12010.

DUNSMOOR, J. E.; PAZ, R. Fear Generalization and Anxiety: Behavioral and Neural Mechanisms. Biol Psychiatry, 78, n. 5, p. 336-343, Sep 12015.

EGERTOVA, M.; GIANG, D. K.; CRAVATT, B. F.; ELPHICK, M. R. A new perspective on cannabinoid signalling: complementary localization of fatty acid amide hydrolase and the CB1 receptor in rat brain. Proc Biol Sci, 265, n. 1410, p. 2081-2085, Nov 71998.

ELBATSH, M. M.; ASSAREH, N.; MARSDEN, C. A.; KENDALL, D. A. Anxiogenic-like effects of chronic cannabidiol administration in rats. Psychopharmacology (Berl), 221, n. 2, p. 239-247, May 2012. 
ESPOSITO, G.; SCUDERI, C.; SAVANI, C.; STEARDO, L., Jr. et al. Cannabidiol in vivo blunts beta-amyloid induced neuroinflammation by suppressing IL-1beta and iNOS expression. Br $\mathbf{J}$ Pharmacol, 151, n. 8, p. 1272-1279, Aug 2007.

ESTES, M. L.; MCALLISTER, A. K. Alterations in immune cells and mediators in the brain: it's not always neuroinflammation! Brain Pathol, 24, n. 6, p. 623-630, Nov 2014.

FENG, X.; ZHAO, Y.; YANG, T.; SONG, M. et al. Glucocorticoid-Driven NLRP3 Inflammasome Activation in Hippocampal Microglia Mediates Chronic Stress-Induced Depressive-Like Behaviors. Front Mol Neurosci, 12, p. 210, 2019.

FERNANDES, J.; GUPTA, G. L. N-acetylcysteine attenuates neuroinflammation associated depressive behavior induced by chronic unpredictable mild stress in rat. Behav Brain Res, 364, p. 356-365, May 172019.

FILIOU, M. D.; WEBHOFER, C.; GORMANNS, P.; ZHANG, Y. et al. The (15)N isotope effect as a means for correlating phenotypic alterations and affected pathways in a trait anxiety mouse model. Proteomics, 12, n. 15-16, p. 2421-2427, Aug 2012.

FILIOU, M. D.; ZHANG, Y.; TEPLYTSKA, L.; RECKOW, S. et al. Proteomics and metabolomics analysis of a trait anxiety mouse model reveals divergent mitochondrial pathways. Biol Psychiatry, 70, n. 11, p. 1074-1082, Dec 12011.

FINSTERWALD, C.; ALBERINI, C. M. Stress and glucocorticoid receptor-dependent mechanisms in long-term memory: from adaptive responses to psychopathologies. Neurobiol Learn Mem, 112, p. 17-29, Jul 2014.

FLANDREAU, E. I.; TOTH, M. Animal Models of PTSD: A Critical Review. Curr Top Behav Neurosci, 38, p. 47-68, 2018.

FOGACA, M. V.; CAMPOS, A. C.; COELHO, L. D.; DUMAN, R. S. et al. The anxiolytic effects of cannabidiol in chronically stressed mice are mediated by the endocannabinoid system: Role of neurogenesis and dendritic remodeling. Neuropharmacology, 135, p. 22-33, Jun 2018.

FOGACA, M. V.; REIS, F. M.; CAMPOS, A. C.; GUIMARAES, F. S. Effects of intra-prelimbic prefrontal cortex injection of cannabidiol on anxiety-like behavior: involvement of 5HT1A receptors and previous stressful experience. Eur Neuropsychopharmacol, 24, n. 3, p. 410-419, Mar 2014.

FRANCHI, L.; WARNER, N.; VIANI, K.; NUNEZ, G. Function of Nod-like receptors in microbial recognition and host defense. Immunol Rev, 227, n. 1, p. 106-128, Jan 2009. 
FRANK, M. G.; HERSHMAN, S. A.; WEBER, M. D.; WATKINS, L. R. et al. Chronic exposure to exogenous glucocorticoids primes microglia to pro-inflammatory stimuli and induces NLRP3 mRNA in the hippocampus. Psychoneuroendocrinology, 40, p. 191-200, Feb 2014.

FRANK, M. G.; MIGUEL, Z. D.; WATKINS, L. R.; MAIER, S. F. Prior exposure to glucocorticoids sensitizes the neuroinflammatory and peripheral inflammatory responses to $\mathrm{E}$. coli lipopolysaccharide. Brain Behav Immun, 24, n. 1, p. 19-30, Jan 2010.

FRICK, L. R.; WILLIAMS, K.; PITTENGER, C. Microglial dysregulation in psychiatric disease. Clin Dev Immunol, 2013, p. 608654, 2013.

FROST, J. L.; SCHAFER, D. P. Microglia: Architects of the Developing Nervous System. Trends Cell Biol, 26, n. 8, p. 587-597, Aug 2016.

GERACIOTI, T. D., Jr.; BAKER, D. G.; EKHATOR, N. N.; WEST, S. A. et al. CSF norepinephrine concentrations in posttraumatic stress disorder. Am J Psychiatry, 158, n. 8, p. 1227-1230, Aug 2001.

GINHOUX, F.; GRETER, M.; LEBOEUF, M.; NANDI, S. et al. Fate mapping analysis reveals that adult microglia derive from primitive macrophages. Science, 330 , n. 6005 , p. $841-845$, Nov 52010.

GOLD, P. W. The organization of the stress system and its dysregulation in depressive illness. Mol Psychiatry, 20, n. 1, p. 32-47, Feb 2015.

GOMES-LEAL, W. Microglial physiopathology: how to explain the dual role of microglia after acute neural disorders? Brain Behav, 2, n. 3, p. 345-356, May 2012.

GOMES, F. V.; ALVES, F. H.; GUIMARAES, F. S.; CORREA, F. M. et al. Cannabidiol administration into the bed nucleus of the stria terminalis alters cardiovascular responses induced by acute restraint stress through 5-HT(1)A receptor. Eur Neuropsychopharmacol, 23, n. 9, p. 1096-1104, Sep 2013.

GOMES, F. V.; DEL BEL, E. A.; GUIMARAES, F. S. Cannabidiol attenuates catalepsy induced by distinct pharmacological mechanisms via 5-HT1A receptor activation in mice. Prog Neuropsychopharmacol Biol Psychiatry, 46, p. 43-47, Oct 12013.

GOMES, F. V.; LLORENTE, R.; DEL BEL, E. A.; VIVEROS, M. P. et al. Decreased glial reactivity could be involved in the antipsychotic-like effect of cannabidiol. Schizophr Res, 164, n. 1-3, p. 155-163, May 2015.

GOMEZ PERDIGUERO, E.; KLAPPROTH, K.; SCHULZ, C.; BUSCH, K. et al. Tissue-resident macrophages originate from yolk-sac-derived erythro-myeloid progenitors. Nature, 518, n. 7540, p. 547-551, Feb 262015. 
GOSHEN, I.; KREISEL, T.; BEN-MENACHEM-ZIDON, O.; LICHT, T. et al. Brain interleukin1 mediates chronic stress-induced depression in mice via adrenocortical activation and hippocampal neurogenesis suppression. Mol Psychiatry, 13, n. 7, p. 717-728, Jul 2008.

GUIMARAES, F. S.; CHIARETTI, T. M.; GRAEFF, F. G.; ZUARDI, A. W. Antianxiety effect of cannabidiol in the elevated plus-maze. Psychopharmacology (Berl), 100, n. 4, p. 558-559, 1990.

GURUNG, P.; LI, B.; SUBBARAO MALIREDDI, R. K.; LAMKANFI, M. et al. Chronic TLR Stimulation Controls NLRP3 Inflammasome Activation through IL-10 Mediated Regulation of NLRP3 Expression and Caspase-8 Activation. Sci Rep, 5, p. 14488, Sep 282015.

HALle, A.; HORNUNG, V.; PETZOLD, G. C.; STEWART, C. R. et al. The NALP3 inflammasome is involved in the innate immune response to amyloid-beta. Nat Immunol, 9, n. 8, p. 857-865, Aug 2008.

HANEKLAUS, M.; O'NEILL, L. A.; COLL, R. C. Modulatory mechanisms controlling the NLRP3 inflammasome in inflammation: recent developments. Curr Opin Immunol, 25, n. 1, p. 40-45, Feb 2013.

HANISCH, U. K.; KETTENMANN, H. Microglia: active sensor and versatile effector cells in the normal and pathologic brain. Nat Neurosci, 10, n. 11, p. 1387-1394, Nov 2007.

HANNESTAD, J.; DELLAGIOIA, N.; BLOCH, M. The effect of antidepressant medication treatment on serum levels of inflammatory cytokines: a meta-analysis. Neuropsychopharmacology, 36, n. 12, p. 2452-2459, Nov 2011.

HARTMANN, A.; LISBOA, S. F.; SONEGO, A. B.; COUTINHO, D. et al. Cannabidiol attenuates aggressive behavior induced by social isolation in mice: Involvement of 5-HT1A and CB1 receptors. Prog Neuropsychopharmacol Biol Psychiatry, 94, p. 109637, Aug 302019.

HASHIMOTO, D.; CHOW, A.; NOIZAT, C.; TEO, P. et al. Tissue-resident macrophages selfmaintain locally throughout adult life with minimal contribution from circulating monocytes. Immunity, 38, n. 4, p. 792-804, Apr 182013.

HEINZ, D. E.; GENEWSKY, A.; WOTJAK, C. T. Enhanced anandamide signaling reduces flight behavior elicited by an approaching robo-beetle. Neuropharmacology, 126, p. 233-241, Nov 2017.

HENDRICKSON, R. C.; RASKIND, M. A. Noradrenergic dysregulation in the pathophysiology of PTSD. Exp Neurol, 284, n. Pt B, p. 181-195, Oct 2016. 
HERKENHAM, M.; LYNN, A. B.; LITTLE, M. D.; JOHNSON, M. R. et al. Cannabinoid receptor localization in brain. Proc Natl Acad Sci U S A, 87, n. 5, p. 1932-1936, Mar 1990.

HERMOSO, M. A.; MATSUGUCHI, T.; SMOAK, K.; CIDLOWSKI, J. A. Glucocorticoids and tumor necrosis factor alpha cooperatively regulate toll-like receptor 2 gene expression. Mol Cell Biol, 24, n. 11, p. 4743-4756, Jun 2004.

HORI, H.; KIM, Y. Inflammation and post-traumatic stress disorder. Psychiatry Clin Neurosci, 73, n. 4, p. 143-153, Apr 2019.

HOWREN, M. B.; LAMKIN, D. M.; SULS, J. Associations of depression with C-reactive protein, IL-1, and IL-6: a meta-analysis. Psychosom Med, 71, n. 2, p. 171-186, Feb 2009.

HUANG, T. L.; LIN, C. C. Advances in biomarkers of major depressive disorder. Adv Clin Chem, 68, p. 177-204, 2015.

ILAHI, S.; ILAHI, T. B. Anatomy, Adenohypophysis (Pars Anterior, Anterior Pituitary). In: StatPearls. Treasure Island (FL), 2020.

IWATA, M.; OTA, K. T.; DUMAN, R. S. The inflammasome: pathways linking psychological stress, depression, and systemic illnesses. Brain Behav Immun, 31, p. 105-114, Jul 2013.

JANELIDZE, S.; MATTEI, D.; WESTRIN, A.; TRASKMAN-BENDZ, L. et al. Cytokine levels in the blood may distinguish suicide attempters from depressed patients. Brain Behav Immun, 25, n. 2, p. 335-339, Feb 2011.

JIANG, W.; ZHANG, Y.; XIAO, L.; VAN CLEEMPUT, J. et al. Cannabinoids promote embryonic and adult hippocampus neurogenesis and produce anxiolytic- and antidepressant-like effects. J Clin Invest, 115, n. 11, p. 3104-3116, Nov 2005.

JUKNAT, A.; GAO, F.; COPPOLA, G.; VOGEL, Z. et al. miRNA expression profiles and molecular networks in resting and LPS-activated BV-2 microglia-Effect of cannabinoids. PLoS One, 14, n. 2, p. e0212039, 2019.

KALISCH, R.; KORENFELD, E.; STEPHAN, K. E.; WEISKOPF, N. et al. Context-dependent human extinction memory is mediated by a ventromedial prefrontal and hippocampal network. $\mathbf{J}$ Neurosci, 26, n. 37, p. 9503-9511, Sep 132006.

KAO, C. Y.; ANDERZHANOVA, E.; ASARA, J. M.; WOTJAK, C. T. et al. NextGen Brain Microdialysis: Applying Modern Metabolomics Technology to the Analysis of Extracellular Fluid in the Central Nervous System. Mol Neuropsychiatry, 1, n. 1, p. 60-67, May 2015. 
KAO, C. Y.; HE, Z.; HENES, K.; ASARA, J. M. et al. Fluoxetine Treatment Rescues Energy Metabolism Pathway Alterations in a Posttraumatic Stress Disorder Mouse Model. Mol Neuropsychiatry, 2, n. 1, p. 46-59, May 2016.

KAO, C. Y.; HE, Z.; ZANNAS, A. S.; HAHN, O. et al. Fluoxetine treatment prevents the inflammatory response in a mouse model of posttraumatic stress disorder. J Psychiatr Res, 76, p. 74-83, May 2016.

KAPLAN, B. L.; SPRINGS, A. E.; KAMINSKI, N. E. The profile of immune modulation by cannabidiol (CBD) involves deregulation of nuclear factor of activated T cells (NFAT). Biochem Pharmacol, 76, n. 6, p. 726-737, Sep 152008.

KAPLAN, G. B.; MOORE, K. A. The use of cognitive enhancers in animal models of fear extinction. Pharmacol Biochem Behav, 99, n. 2, p. 217-228, Aug 2011.

KAREGE, F.; PERRET, G.; BONDOLFI, G.; SCHWALD, M. et al. Decreased serum brainderived neurotrophic factor levels in major depressed patients. Psychiatry Res, 109, n. 2, p. 143148, Mar 152002.

KESSLER, R. C.; HEERINGA, S.; LAKOMA, M. D.; PETUKHOVA, M. et al. Individual and societal effects of mental disorders on earnings in the United States: results from the national comorbidity survey replication. Am J Psychiatry, 165, n. 6, p. 703-711, Jun 2008.

KESSLER, R. C.; WANG, P. S. The descriptive epidemiology of commonly occurring mental disorders in the United States. Annu Rev Public Health, 29, p. 115-129, 2008.

KIERDORF, K.; ERNY, D.; GOLDMANN, T.; SANDER, V. et al. Microglia emerge from erythromyeloid precursors via Pu.1- and Irf8-dependent pathways. Nat Neurosci, 16, n. 3, p. 273 280, Mar 2013.

KIM, J. Y.; KIM, N.; YENARI, M. A. Mechanisms and potential therapeutic applications of microglial activation after brain injury. CNS Neurosci Ther, 21, n. 4, p. 309-319, Apr 2015.

KOENEN, K. C.; RATANATHARATHORN, A.; NG, L.; MClAUGHLIN, K. A. et al. Posttraumatic stress disorder in the World Mental Health Surveys. Psychol Med, 47, n. 13, p. 2260-2274, Oct 2017.

KOENIGS, M.; GRAFMAN, J. Posttraumatic stress disorder: the role of medial prefrontal cortex and amygdala. Neuroscientist, 15, n. 5, p. 540-548, Oct 2009.

KONG, E.; SUCIC, S.; MONJE, F. J.; SAVALLI, G. et al. STAT3 controls IL6-dependent regulation of serotonin transporter function and depression-like behavior. Sci Rep, 5, p. 9009, Mar 112015. 
KOO, J. W.; DUMAN, R. S. IL-1beta is an essential mediator of the antineurogenic and anhedonic effects of stress. Proc Natl Acad Sci U S A, 105, n. 2, p. 751-756, Jan 152008.

KROMER, S. A.; KESSLER, M. S.; MILFAY, D.; BIRG, I. N. et al. Identification of glyoxalaseI as a protein marker in a mouse model of extremes in trait anxiety. $\mathbf{J}$ Neurosci, 25, n. 17, p. 43754384, Apr 272005.

LABAR, K. S.; GATENBY, J. C.; GORE, J. C.; LEDOUX, J. E. et al. Human amygdala activation during conditioned fear acquisition and extinction: a mixed-trial fMRI study. Neuron, 20, n. 5, p. 937-945, May 1998.

LANDGRAF, R.; KESSLER, M. S.; BUNCK, M.; MURGATROYD, C. et al. Candidate genes of anxiety-related behavior in $\mathrm{HAB} / \mathrm{LAB}$ rats and mice: focus on vasopressin and glyoxalase-I. Neurosci Biobehav Rev, 31, n. 1, p. 89-102, 2007.

LAPIZ-BLUHM, M. D.; PETERSON, A. L. Neurobehavioral Mechanisms of Traumatic Stress in Post-traumatic Stress Disorder. Curr Top Behav Neurosci, 18, p. 161-190, 2014.

LEMOS, J. I.; RESSTEL, L. B.; GUIMARAES, F. S. Involvement of the prelimbic prefrontal cortex on cannabidiol-induced attenuation of contextual conditioned fear in rats. Behav Brain Res, 207, n. 1, p. 105-111, Feb 112010.

LEO, R.; DI LORENZO, G.; TESAURO, M.; RAZZINI, C. et al. Association between enhanced soluble CD40 ligand and proinflammatory and prothrombotic states in major depressive disorder: pilot observations on the effects of selective serotonin reuptake inhibitor therapy. J Clin Psychiatry, 67, n. 11, p. 1760-1766, Nov 2006.

LEVIN, R.; ALMEIDA, V.; PERES, F. F.; CALZAVARA, M. B. et al. Antipsychotic profile of cannabidiol and rimonabant in an animal model of emotional context processing in schizophrenia. Curr Pharm Des, 18, n. 32, p. 4960-4965, 2012.

LEVINE, J.; BARAK, Y.; CHENGAPPA, K. N.; RAPOPORT, A. et al. Cerebrospinal cytokine levels in patients with acute depression. Neuropsychobiology, 40, n. 4, p. 171-176, Nov 1999.

LIBERMAN, A. C.; DRUKER, J.; PERONE, M. J.; ARZT, E. Glucocorticoids in the regulation of transcription factors that control cytokine synthesis. Cytokine Growth Factor Rev, 18, n. 12, p. 45-56, Feb-Apr 2007.

LIBRO, R.; SCIONTI, D.; DIOMEDE, F.; MARCHISIO, M. et al. Cannabidiol Modulates the Immunophenotype and Inhibits the Activation of the Inflammasome in Human Gingival Mesenchymal Stem Cells. Front Physiol, 7, p. 559, 2016. 
LINDQVIST, D.; JANELIDZE, S.; HAGELL, P.; ERHARDT, S. et al. Interleukin-6 is elevated in the cerebrospinal fluid of suicide attempters and related to symptom severity. Biol Psychiatry, 66, n. 3, p. 287-292, Aug 12009.

LISBOA, S. F.; GOMES, F. V.; GUIMARAES, F. S.; CAMPOS, A. C. Microglial Cells as a Link between Cannabinoids and the Immune Hypothesis of Psychiatric Disorders. Front Neurol, 7, p. $5,2016$.

LISBOA, S. F.; NIRAULA, A.; RESSTEL, L. B.; GUIMARAES, F. S. et al. Repeated social defeat-induced neuroinflammation, anxiety-like behavior and resistance to fear extinction were attenuated by the cannabinoid receptor agonist WIN55,212-2. Neuropsychopharmacology, 43, n. 9, p. 1924-1933, Aug 2018.

LIU, C.; MA, H.; SLITT, A. L.; SEERAM, N. P. Inhibitory Effect of Cannabidiol on the Activation of NLRP3 Inflammasome Is Associated with Its Modulation of the P2X7 Receptor in Human Monocytes. J Nat Prod, 83, n. 6, p. 2025-2029, Jun 262020.

LIU, D. Z.; HU, C. M.; HUANG, C. H.; WEY, S. P. et al. Cannabidiol attenuates delayed-type hypersensitivity reactions via suppressing T-cell and macrophage reactivity. Acta Pharmacol Sin, 31, n. 12, p. 1611-1617, Dec 2010.

LIU, X.; QUAN, N. Microglia and CNS Interleukin-1: Beyond Immunological Concepts. Front Neurol, 9, p. 8, 2018.

LOHOFF, F. W. Overview of the genetics of major depressive disorder. Curr Psychiatry Rep, 12, n. 6, p. 539-546, Dec 2010.

LUPIEN, S. J.; MAHEU, F.; TU, M.; FIOCCO, A. et al. The effects of stress and stress hormones on human cognition: Implications for the field of brain and cognition. Brain Cogn, 65, n. 3, p. 209-237, Dec 2007.

LUTZ, B.; MARSICANO, G.; MALDONADO, R.; HILLARD, C. J. The endocannabinoid system in guarding against fear, anxiety and stress. Nat Rev Neurosci, 16, n. 12, p. 705-718, Dec 2015.

MAES, M. Evidence for an immune response in major depression: a review and hypothesis. Prog Neuropsychopharmacol Biol Psychiatry, 19, n. 1, p. 11-38, Jan 1995.

MAES, M.; YIRMYIA, R.; NORABERG, J.; BRENE, S. et al. The inflammatory \& neurodegenerative (I\&ND) hypothesis of depression: leads for future research and new drug developments in depression. Metab Brain Dis, 24, n. 1, p. 27-53, Mar 2009.

MAIER, S. F.; WATKINS, L. R.; FLESHNER, M. Psychoneuroimmunology. The interface between behavior, brain, and immunity. Am Psychol, 49, n. 12, p. 1004-1017, Dec 1994. 
MARTINON, F. Signaling by ROS drives inflammasome activation. Eur J Immunol, 40, n. 3, p. 616-619, Mar 2010.

MARTINON, F.; BURNS, K.; TSCHOPP, J. The inflammasome: a molecular platform triggering activation of inflammatory caspases and processing of proIL-beta. Mol Cell, 10, n. 2, p. 417-426, Aug 2002.

MARTINON, F.; MAYOR, A.; TSCHOPP, J. The inflammasomes: guardians of the body. Annu Rev Immunol, 27, p. 229-265, 2009.

MASATAKA, N. Anxiolytic Effects of Repeated Cannabidiol Treatment in Teenagers With Social Anxiety Disorders. Front Psychol, 10, p. 2466, 2019.

MCEWEN, B. S. Stress, adaptation, and disease. Allostasis and allostatic load. Ann N Y Acad Sci, 840, p. 33-44, May 11998.

MCEWEN, B. S. The neurobiology of stress: from serendipity to clinical relevance. Brain Res, 886, n. 1-2, p. 172-189, Dec 152000.

MCEWEN, B. S.; GIANAROS, P. J. Central role of the brain in stress and adaptation: links to socioeconomic status, health, and disease. Ann N Y Acad Sci, 1186, p. 190-222, Feb 2010.

MCEWEN, B. S.; GOULD, E. A.; SAKAI, R. R. The vulnerability of the hippocampus to protective and destructive effects of glucocorticoids in relation to stress. Br J Psychiatry Suppl, n. 15, p. 18-23, Feb 1992.

MCKIM, D. B.; WEBER, M. D.; NIRAULA, A.; SAWICKI, C. M. et al. Microglial recruitment of IL-1beta-producing monocytes to brain endothelium causes stress-induced anxiety. Mol Psychiatry, 23, n. 6, p. 1421-1431, Jun 2018.

MECHA, M.; FELIU, A.; CARRILLO-SALINAS, F. J.; RUEDA-ZUBIAURRE, A. et al. Endocannabinoids drive the acquisition of an alternative phenotype in microglia. Brain Behav Immun, 49, p. 233-245, Oct 2015.

MECHA, M.; FELIU, A.; INIGO, P. M.; MESTRE, L. et al. Cannabidiol provides long-lasting protection against the deleterious effects of inflammation in a viral model of multiple sclerosis: a role for A2A receptors. Neurobiol Dis, 59, p. 141-150, Nov 2013.

MEIJSING, S. H.; ELBI, C.; LUECKE, H. F.; HAGER, G. L. et al. The ligand binding domain controls glucocorticoid receptor dynamics independent of ligand release. Mol Cell Biol, 27, n. 7, p. 2442-2451, Apr 2007. 
MEIJSING, S. H.; PUFALL, M. A.; SO, A. Y.; BATES, D. L. et al. DNA binding site sequence directs glucocorticoid receptor structure and activity. Science, 324, n. 5925, p. 407-410, Apr 17 2009.

MENARD, C.; PFAU, M. L.; HODES, G. E.; RUSSO, S. J. Immune and Neuroendocrine Mechanisms of Stress Vulnerability and Resilience. Neuropsychopharmacology, 42, n. 1, p. 62 80, Jan 2017.

MENDOZA, C.; BARRETO, G. E.; AVILA-RODRIGUEZ, M.; ECHEVERRIA, V. Role of neuroinflammation and sex hormones in war-related PTSD. Mol Cell Endocrinol, 434, p. 266277, Oct 152016.

MERALI, Z.; BRENNAN, K.; BRAU, P.; ANISMAN, H. Dissociating anorexia and anhedonia elicited by interleukin-1 beta: antidepressant and gender effects on responding for "free chow" and "earned" sucrose intake. Psychopharmacology (Berl), 165, n. 4, p. 413-418, Feb 2003.

MILAD, M. R.; PITMAN, R. K.; ELLIS, C. B.; GOLD, A. L. et al. Neurobiological basis of failure to recall extinction memory in posttraumatic stress disorder. Biol Psychiatry, 66, n. 12, p. 1075-1082, Dec 152009.

MILAD, M. R.; QUIRK, G. J. Fear extinction as a model for translational neuroscience: ten years of progress. Annu Rev Psychol, 63, p. 129-151, 2012.

MILAD, M. R.; WRIGHT, C. I.; ORR, S. P.; PITMAN, R. K. et al. Recall of fear extinction in humans activates the ventromedial prefrontal cortex and hippocampus in concert. Biol Psychiatry, 62, n. 5, p. 446-454, Sep 12007.

MONDELLI, V.; VERNON, A. C.; TURKHEIMER, F.; DAZZAN, P. et al. Brain microglia in psychiatric disorders. Lancet Psychiatry, 4, n. 7, p. 563-572, Jul 2017.

MONJE, F. J.; CABATIC, M.; DIVISCH, I.; KIM, E. J. et al. Constant darkness induces IL-6dependent depression-like behavior through the NF-kappaB signaling pathway. J Neurosci, 31, n. 25, p. 9075-9083, Jun 222011.

MOREIRA, F. A.; AGUIAR, D. C.; GUIMARAES, F. S. Anxiolytic-like effect of cannabidiol in the rat Vogel conflict test. Prog Neuropsychopharmacol Biol Psychiatry, 30, n. 8, p. 14661471, Dec 302006.

NEYLAN, T. C.; SUN, B.; REMPEL, H.; ROSS, J. et al. Suppressed monocyte gene expression profile in men versus women with PTSD. Brain Behav Immun, 25, n. 3, p. 524-531, Mar 2011.

NORDEN, D. M.; TROJANOWSKI, P. J.; VILLANUEVA, E.; NAVARRO, E. et al. Sequential activation of microglia and astrocyte cytokine expression precedes increased Iba-1 or GFAP immunoreactivity following systemic immune challenge. Glia, 64, n. 2, p. 300-316, Feb 2016. 
NUSSBAUMER, M.; ASARA, J. M.; TEPLYTSKA, L.; MURPHY, M. P. et al. Selective Mitochondrial Targeting Exerts Anxiolytic Effects In Vivo. Neuropsychopharmacology, 41, n. 7, p. 1751-1758, Jun 2016.

OVERSTREET, D. H.; WEGENER, G. The flinders sensitive line rat model of depression--25 years and still producing. Pharmacol Rev, 65, n. 1, p. 143-155, Jan 2013.

OWEN, B. M.; ECCLESTON, D.; FERRIER, I. N.; YOUNG, A. H. Raised levels of plasma interleukin-1beta in major and postviral depression. Acta Psychiatr Scand, 103, n. 3, p. 226-228, Mar 2001.

PALAZUELOS, J.; AGUADO, T.; EGIA, A.; MECHOULAM, R. et al. Non-psychoactive CB2 cannabinoid agonists stimulate neural progenitor proliferation. FASEB J, 20, n. 13, p. 2405-2407, Nov 2006.

PAN, Y.; CHEN, X. Y.; ZHANG, Q. Y.; KONG, L. D. Microglial NLRP3 inflammasome activation mediates IL-1beta-related inflammation in prefrontal cortex of depressive rats. Brain Behav Immun, 41, p. 90-100, Oct 2014.

PANDEY, G. N.; DWIVEDI, Y. Neurobiology of Teenage Suicide. In: DWIVEDI, Y. (Ed.). The Neurobiological Basis of Suicide. Boca Raton (FL), 2012. (Frontiers in Neuroscience).

PANDEY, G. N.; RIZAVI, H. S.; REN, X.; FAREED, J. et al. Proinflammatory cytokines in the prefrontal cortex of teenage suicide victims. J Psychiatr Res, 46, n. 1, p. 57-63, Jan 2012.

PASSOS, I. C.; VASCONCELOS-MORENO, M. P.; COSTA, L. G.; KUNZ, M. et al. Inflammatory markers in post-traumatic stress disorder: a systematic review, meta-analysis, and meta-regression. Lancet Psychiatry, 2, n. 11, p. 1002-1012, Nov 2015.

PEDRAZZI, J. F.; ISSY, A. C.; GOMES, F. V.; GUIMARAES, F. S. et al. Cannabidiol effects in the prepulse inhibition disruption induced by amphetamine. Psychopharmacology (Berl), 232, n. 16, p. 3057-3065, Aug 2015.

PERI, T.; BEN-SHAKHAR, G.; ORR, S. P.; SHALEV, A. Y. Psychophysiologic assessment of aversive conditioning in posttraumatic stress disorder. Biol Psychiatry, 47, n. 6, p. 512-519, Mar 152000 .

PHELPS, E. A.; DELGADO, M. R.; NEARING, K. I.; LEDOUX, J. E. Extinction learning in humans: role of the amygdala and vmPFC. Neuron, 43, n. 6, p. 897-905, Sep 162004.

PRINZ, M.; PRILLER, J. Microglia and brain macrophages in the molecular age: from origin to neuropsychiatric disease. Nat Rev Neurosci, 15, n. 5, p. 300-312, May 2014. 
PYTKA, K.; PODKOWA, K.; RAPACZ, A.; PODKOWA, A. et al. The role of serotonergic, adrenergic and dopaminergic receptors in antidepressant-like effect. Pharmacol Rep, 68, n. 2, p. 263-274, Apr 2016.

QUIRK, G. J.; MUELLER, D. Neural mechanisms of extinction learning and retrieval. Neuropsychopharmacology, 33, n. 1, p. 56-72, Jan 2008.

RABINAK, C. A.; ANGSTADT, M.; LYONS, M.; MORI, S. et al. Cannabinoid modulation of prefrontal-limbic activation during fear extinction learning and recall in humans. Neurobiol Learn Mem, 113, p. 125-134, Sep 2014.

RAMAMOORTHY, S.; RAMAMOORTHY, J. D.; PRASAD, P. D.; BHAT, G. K. et al. Regulation of the human serotonin transporter by interleukin-1 beta. Biochem Biophys Res Commun, 216, n. 2, p. 560-567, Nov 131995.

RANSOHOFF, R. M. A polarizing question: do M1 and M2 microglia exist? Nat Neurosci, 19, n. 8, p. 987-991, Jul 262016.

RANSOHOFF, R. M.; BROWN, M. A. Innate immunity in the central nervous system. J Clin Invest, 122, n. 4, p. 1164-1171, Apr 2012.

RANSOHOFF, R. M.; PERRY, V. H. Microglial physiology: unique stimuli, specialized responses. Annu Rev Immunol, 27, p. 119-145, 2009.

RASHID, S.; LEWIS, G. F. The mechanisms of differential glucocorticoid and mineralocorticoid action in the brain and peripheral tissues. Clin Biochem, 38, n. 5, p. 401-409, May 2005.

RAY, A.; GULATI, K.; RAI, N. Stress, Anxiety, and Immunomodulation: A Pharmacological Analysis. Vitam Horm, 103, p. 1-25, 2017.

REICHENBERG, A.; YIRMIYA, R.; SCHULD, A.; KRAUS, T. et al. Cytokine-associated emotional and cognitive disturbances in humans. Arch Gen Psychiatry, 58, n. 5, p. 445-452, May 2001.

RESSTEL, L. B.; JOCA, S. R.; MOREIRA, F. A.; CORREA, F. M. et al. Effects of cannabidiol and diazepam on behavioral and cardiovascular responses induced by contextual conditioned fear in rats. Behav Brain Res, 172, n. 2, p. 294-298, Sep 252006.

RESSTEL, L. B.; TAVARES, R. F.; LISBOA, S. F.; JOCA, S. R. et al. 5-HT1A receptors are involved in the cannabidiol-induced attenuation of behavioural and cardiovascular responses to acute restraint stress in rats. Br J Pharmacol, 156, n. 1, p. 181-188, Jan 2009. 
RHEN, T.; CIDLOWSKI, J. A. Antiinflammatory action of glucocorticoids--new mechanisms for old drugs. N Engl J Med, 353, n. 16, p. 1711-1723, Oct 202005.

ROHLEDER, N.; JOKSIMOVIC, L.; WOLF, J. M.; KIRSCHBAUM, C. Hypocortisolism and increased glucocorticoid sensitivity of pro-Inflammatory cytokine production in Bosnian war refugees with posttraumatic stress disorder. Biol Psychiatry, 55, n. 7, p. 745-751, Apr 12004.

RUSSELL, G.; LIGHTMAN, S. The human stress response. Nat Rev Endocrinol, 15, n. 9, p. 525-534, Sep 2019.

RUSSO, E. B.; BURNETT, A.; HALL, B.; PARKER, K. K. Agonistic properties of cannabidiol at 5-HT1a receptors. Neurochem Res, 30, n. 8, p. 1037-1043, Aug 2005.

RYBERG, E.; LARSSON, N.; SJOGREN, S.; HJORTH, S. et al. The orphan receptor GPR55 is a novel cannabinoid receptor. Br J Pharmacol, 152, n. 7, p. 1092-1101, Dec 2007.

SAH, A.; SCHMUCKERMAIR, C.; SARTORI, S. B.; GABURRO, S. et al. Anxiety- rather than depression-like behavior is associated with adult neurogenesis in a female mouse model of higher trait anxiety- and comorbid depression-like behavior. Transl Psychiatry, 2, p. e171, Oct 162012.

SANDFORD, J. J.; ARGYROPOULOS, S. V.; NUTT, D. J. The psychobiology of anxiolytic drugs. Part 1: Basic neurobiology. Pharmacol Ther, 88, n. 3, p. 197-212, Dec 2000.

SARTORI, S. B.; HAUSCHILD, M.; BUNCK, M.; GABURRO, S. et al. Enhanced fear expression in a psychopathological mouse model of trait anxiety: pharmacological interventions. PLoS One, 6, n. 2, p. e16849, Feb 282011.

SCHAUFLER, J.; RONOVSKY, M.; SAVALLI, G.; CABATIC, M. et al. Fluoxetine normalizes disrupted light-induced entrainment, fragmented ultradian rhythms and altered hippocampal clock gene expression in an animal model of high trait anxiety- and depression-related behavior. Ann Med, 48, n. 1-2, p. 17-27, 2016.

SCHIEPERS, O. J.; WICHERS, M. C.; MAES, M. Cytokines and major depression. Prog Neuropsychopharmacol Biol Psychiatry, 29, n. 2, p. 201-217, Feb 2005.

SCHRODER, K.; ZHOU, R.; TSCHOPP, J. The NLRP3 inflammasome: a sensor for metabolic danger? Science, 327, n. 5963, p. 296-300, Jan 152010.

SCHULZ, C.; GOMEZ PERDIGUERO, E.; CHORRO, L.; SZABO-ROGERS, H. et al. A lineage of myeloid cells independent of Myb and hematopoietic stem cells. Science, 336, n. 6077, p. 8690, Apr 62012. 
SELYE, H. A syndrome produced by diverse nocuous agents. 1936. J Neuropsychiatry Clin Neurosci, 10, n. 2, p. 230-231, Spring 1998.

SHENG, J.; RUEDL, C.; KARJALAINEN, K. Most Tissue-Resident Macrophages Except Microglia Are Derived from Fetal Hematopoietic Stem Cells. Immunity, 43, n. 2, p. 382-393, Aug 182015.

SHI, R.; SHARPE, L.; ABBOTT, M. A meta-analysis of the relationship between anxiety and attentional control. Clin Psychol Rev, 72, p. 101754, Aug 2019.

SHI, Y.; EVANS, J. E.; ROCK, K. L. Molecular identification of a danger signal that alerts the immune system to dying cells. Nature, 425, n. 6957, p. 516-521, Oct 2003.

SHIN, L. M.; RAUCH, S. L.; PITMAN, R. K. Amygdala, medial prefrontal cortex, and hippocampal function in PTSD. Ann N Y Acad Sci, 1071, p. 67-79, Jul 2006.

SIEGMUND, A.; WOTJAK, C. T. Toward an animal model of posttraumatic stress disorder. Ann N Y Acad Sci, 1071, p. 324-334, Jul 2006.

SIEGMUND, A.; WOTJAK, C. T. Hyperarousal does not depend on trauma-related contextual memory in an animal model of Posttraumatic Stress Disorder. Physiol Behav, 90, n. 1, p. 103107, Jan 30 2007a.

SIEGMUND, A.; WOTJAK, C. T. A mouse model of posttraumatic stress disorder that distinguishes between conditioned and sensitised fear. J Psychiatr Res, 41, n. 10, p. 848-860, Nov $2007 b$.

SIERRA, A.; GOTTFRIED-BLACKMORE, A.; MILNER, T. A.; MCEWEN, B. S. et al. Steroid hormone receptor expression and function in microglia. Glia, 56, n. 6, p. 659-674, Apr 152008.

SLATTERY, D. A.; CRYAN, J. F. The ups and downs of modelling mood disorders in rodents. ILAR J, 55, n. 2, p. 297-309, 2014.

SMOAK, K. A.; CIDLOWSKI, J. A. Mechanisms of glucocorticoid receptor signaling during inflammation. Mech Ageing Dev, 125, n. 10-11, p. 697-706, Oct-Nov 2004.

SONEGO, A. B.; PRADO, D. S.; VALE, G. T.; SEPULVEDA-DIAZ, J. E. et al. Cannabidiol prevents haloperidol-induced vacuos chewing movements and inflammatory changes in mice via PPARgamma receptors. Brain Behav Immun, 74, p. 241-251, Nov 2018.

SRIVASTAVA, M. D.; SRIVASTAVA, B. I.; BROUHARD, B. Delta9 tetrahydrocannabinol and cannabidiol alter cytokine production by human immune cells. Immunopharmacology, 40, n. 3, p. 179-185, Nov 1998. 
STARK, J. L.; AVITSUR, R.; PADGETT, D. A.; CAMPBELL, K. A. et al. Social stress induces glucocorticoid resistance in macrophages. Am J Physiol Regul Integr Comp Physiol, 280, n. 6, p. R1799-1805, Jun 2001.

STECKLER, T.; RISBROUGH, V. Pharmacological treatment of PTSD - established and new approaches. Neuropharmacology, 62, n. 2, p. 617-627, Feb 2012.

STEIN, M. B.; CHEN, C. Y.; URSANO, R. J.; CAI, T. et al. Genome-wide Association Studies of Posttraumatic Stress Disorder in 2 Cohorts of US Army Soldiers. JAMA Psychiatry, 73, n. 7, p. 695-704, Jul 12016.

STELlato, C. Post-transcriptional and nongenomic effects of glucocorticoids. Proc Am Thorac Soc, 1, n. 3, p. 255-263, 2004.

STEPHENS, M. A.; WAND, G. Stress and the HPA axis: role of glucocorticoids in alcohol dependence. Alcohol Res, 34, n. 4, p. 468-483, 2012.

STERN, C. A.; GAZARINI, L.; TAKAHASHI, R. N.; GUIMARAES, F. S. et al. On disruption of fear memory by reconsolidation blockade: evidence from cannabidiol treatment. Neuropsychopharmacology, 37, n. 9, p. 2132-2142, Aug 2012.

STERN, C. A.; GAZARINI, L.; VANVOSSEN, A. C.; ZUARDI, A. W. et al. Delta9Tetrahydrocannabinol alone and combined with cannabidiol mitigate fear memory through reconsolidation disruption. Eur Neuropsychopharmacol, 25, n. 6, p. 958-965, Jun 2015.

STERN, C. A. J.; DA SILVA, T. R.; RAYMUNDI, A. M.; DE SOUZA, C. P. et al. Cannabidiol disrupts the consolidation of specific and generalized fear memories via dorsal hippocampus CB1 and CB2 receptors. Neuropharmacology, 125, p. 220-230, Oct 2017.

SU, W. J.; ZHANG, Y.; CHEN, Y.; GONG, H. et al. NLRP3 gene knockout blocks NF-kappaB and MAPK signaling pathway in CUMS-induced depression mouse model. Behav Brain Res, 322, n. Pt A, p. 1-8, Mar 302017.

SUKOFF RIZZO, S. J.; NEAL, S. J.; HUGHES, Z. A.; BEYNA, M. et al. Evidence for sustained elevation of IL-6 in the CNS as a key contributor of depressive-like phenotypes. Transl Psychiatry, 2, p. e199, Dec 42012.

SUTCIGIL, L.; OKTENLI, C.; MUSABAK, U.; BOZKURT, A. et al. Pro- and anti-inflammatory cytokine balance in major depression: effect of sertraline therapy. Clin Dev Immunol, 2007, p. 76396, 2007.

TAKEUCHI, O.; AKIRA, S. Pattern recognition receptors and inflammation. Cell, 140, n. 6, p. 805-820, Mar 192010. 
TAN, K. S.; NACKLEY, A. G.; SATTERFIELD, K.; MAIXNER, W. et al. Beta2 adrenergic receptor activation stimulates pro-inflammatory cytokine production in macrophages via PKAand NF-kappaB-independent mechanisms. Cell Signal, 19, n. 2, p. 251-260, Feb 2007.

TAN, M. S.; YU, J. T.; JIANG, T.; ZHU, X. C. et al. The NLRP3 inflammasome in Alzheimer's disease. Mol Neurobiol, 48, n. 3, p. 875-882, Dec 2013.

TANG, Y.; LE, W. Differential Roles of M1 and M2 Microglia in Neurodegenerative Diseases. Mol Neurobiol, 53, n. 2, p. 1181-1194, Mar 2016.

TAY, T. L.; MAI, D.; DAUTZENBERG, J.; FERNANDEZ-KLETT, F. et al. A new fate mapping system reveals context-dependent random or clonal expansion of microglia. Nat Neurosci, 20, n. 6, p. 793-803, Jun 2017.

TECOMA, E. S.; HUEY, L. Y. Psychic distress and the immune response. Life Sci, 36, n. 19, p. 1799-1812, May 131985.

THOMAS, A. J.; DAVIS, S.; MORRIS, C.; JACKSON, E. et al. Increase in interleukin-1beta in late-life depression. Am J Psychiatry, 162, n. 1, p. 175-177, Jan 2005.

TORRES-PLATAS, S. G.; CRUCEANU, C.; CHEN, G. G.; TURECKI, G. et al. Evidence for increased microglial priming and macrophage recruitment in the dorsal anterior cingulate white matter of depressed suicides. Brain Behav Immun, 42, p. 50-59, Nov 2014.

TOVOTE, P.; FADOK, J. P.; LUTHI, A. Neuronal circuits for fear and anxiety. Nat Rev Neurosci, 16, n. 6, p. 317-331, Jun 2015.

TURSICH, M.; NEUFELD, R. W.; FREWEN, P. A.; HARRICHARAN, S. et al. Association of trauma exposure with proinflammatory activity: a transdiagnostic meta-analysis. Transl Psychiatry, 4, p. e413, Jul 222014.

UDDIN, M.; AIELLO, A. E.; WILDMAN, D. E.; KOENEN, K. C. et al. Epigenetic and immune function profiles associated with posttraumatic stress disorder. Proc Natl Acad Sci U S A, 107, n. 20, p. 9470-9475, May 182010.

VANELZAKKER, M. B.; DAHLGREN, M. K.; DAVIS, F. C.; DUBOIS, S. et al. From Pavlov to PTSD: the extinction of conditioned fear in rodents, humans, and anxiety disorders. Neurobiol Learn Mem, 113, p. 3-18, Sep 2014.

VUOLO, F.; PETRONILHO, F.; SONAI, B.; RITTER, C. et al. Evaluation of Serum Cytokines Levels and the Role of Cannabidiol Treatment in Animal Model of Asthma. Mediators Inflamm, 2015, p. 538670, 2015. 
WALDHAUSER, G. T.; JOHANSSON, M.; BACKSTROM, M.; MECKLINGER, A. Trait anxiety, working memory capacity, and the effectiveness of memory suppression. Scand $\mathbf{J}$ Psychol, 52, n. 1, p. 21-27, Feb 2011.

WALSH, J. G.; MURUVE, D. A.; POWER, C. Inflammasomes in the CNS. Nat Rev Neurosci, 15, n. 2, p. 84-97, Feb 2014.

WEBER, M. D.; FRANK, M. G.; SOBESKY, J. L.; WATKINS, L. R. et al. Blocking toll-like receptor 2 and 4 signaling during a stressor prevents stress-induced priming of neuroinflammatory responses to a subsequent immune challenge. Brain Behav Immun, 32, p. 112-121, Aug 2013.

WEIKUM, E. R.; KNUESEL, M. T.; ORTLUND, E. A.; YAMAMOTO, K. R. Glucocorticoid receptor control of transcription: precision and plasticity via allostery. Nat Rev Mol Cell Biol, 18, n. 3, p. 159-174, Mar 2017.

WILLNER, P.; MUSCAT, R.; PAPP, M. Chronic mild stress-induced anhedonia: a realistic animal model of depression. Neurosci Biobehav Rev, 16, n. 4, p. 525-534, Winter 1992.

WOHLEB, E. S.; HANKE, M. L.; CORONA, A. W.; POWELL, N. D. et al. beta-Adrenergic receptor antagonism prevents anxiety-like behavior and microglial reactivity induced by repeated social defeat. J Neurosci, 31, n. 17, p. 6277-6288, Apr 272011.

WOHLEB, E. S.; POWELL, N. D.; GODBOUT, J. P.; SHERIDAN, J. F. Stress-induced recruitment of bone marrow-derived monocytes to the brain promotes anxiety-like behavior. $\mathbf{J}$ Neurosci, 33, n. 34, p. 13820-13833, Aug 212013.

WONG, M. L.; INSERRA, A.; LEWIS, M. D.; MASTRONARDI, C. A. et al. Inflammasome signaling affects anxiety- and depressive-like behavior and gut microbiome composition. Mol Psychiatry, 21, n. 6, p. 797-805, Jun 2016.

YEHUDA, R.; BOISONEAU, D.; LOWY, M. T.; GILLER, E. L., Jr. Dose-response changes in plasma cortisol and lymphocyte glucocorticoid receptors following dexamethasone administration in combat veterans with and without posttraumatic stress disorder. Arch Gen Psychiatry, 52, n. 7, p. 583-593, Jul 1995.

YEHUDA, R.; HOGE, C. W.; MCFARLANE, A. C.; VERMETTEN, E. et al. Post-traumatic stress disorder. Nat Rev Dis Primers, 1, p. 15057, Oct 82015.

YEHUDA, R.; SOUTHWICK, S. M.; NUSSBAUM, G.; WAHBY, V. et al. Low urinary cortisol excretion in patients with posttraumatic stress disorder. J Nerv Ment Dis, 178, n. 6, p. 366-369, Jun 1990. 
YEHUDA, R.; TEICHER, M. H.; TRESTMAN, R. L.; LEVENGOOD, R. A. et al. Cortisol regulation in posttraumatic stress disorder and major depression: a chronobiological analysis. Biol Psychiatry, 40, n. 2, p. 79-88, Jul 151996.

YEN, Y. C.; ANDERZHANOVA, E.; BUNCK, M.; SCHULLER, J. et al. Co-segregation of hyperactivity, active coping styles, and cognitive dysfunction in mice selectively bred for low levels of anxiety. Front Behav Neurosci, 7, p. 103, 2013.

YEN, Y. C.; MAUCH, C. P.; DAHLHOFF, M.; MICALE, V. et al. Increased levels of conditioned fear and avoidance behavior coincide with changes in phosphorylation of the protein kinase B (AKT) within the amygdala in a mouse model of extremes in trait anxiety. Neurobiol Learn Mem, 98, n. 1, p. 56-65, Jul 2012.

YOU, Z.; LUO, C.; ZHANG, W.; CHEN, Y. et al. Pro- and anti-inflammatory cytokines expression in rat's brain and spleen exposed to chronic mild stress: involvement in depression. Behav Brain Res, 225, n. 1, p. 135-141, Nov 202011.

ZANELATI, T. V.; BIOJONE, C.; MOREIRA, F. A.; GUIMARAES, F. S. et al. Antidepressantlike effects of cannabidiol in mice: possible involvement of 5-HT1A receptors. Br J Pharmacol, 159, n. 1, p. 122-128, Jan 2010.

ZHANG, C.; ZHANG, Y. P.; LI, Y. Y.; LIU, B. P. et al. Minocycline ameliorates depressive behaviors and neuro-immune dysfunction induced by chronic unpredictable mild stress in the rat. Behav Brain Res, 356, p. 348-357, Jan 12019.

ZHANG, L.; HU, X. Z.; LI, H.; LI, X. et al. Updates in PTSD Animal Models Characterization. Methods Mol Biol, 2011, p. 331-344, 2019.

ZHANG, Y.; LIU, L.; LIU, Y. Z.; SHEN, X. L. et al. NLRP3 Inflammasome Mediates Chronic Mild Stress-Induced Depression in Mice via Neuroinflammation. Int J Neuropsychopharmacol, 18, n. 8, Jan 202015.

ZHU, C. B.; BLAKELY, R. D.; HEWLETT, W. A. The proinflammatory cytokines interleukinlbeta and tumor necrosis factor-alpha activate serotonin transporters. Neuropsychopharmacology, 31, n. 10, p. 2121-2131, Oct 2006.

ZOLADZ, P. R.; DIAMOND, D. M. Current status on behavioral and biological markers of PTSD: a search for clarity in a conflicting literature. Neurosci Biobehav Rev, 37, n. 5, p. 860895, Jun 2013.

ZUARDI, A. W. Cannabidiol: from an inactive cannabinoid to a drug with wide spectrum of action. Rev Bras Psiquiatr, 30, n. 3, p. 271-280, Sep 2008. 
ZUARDI, A. W.; COSME, R. A.; GRAEFF, F. G.; GUIMARAES, F. S. Effects of ipsapirone and cannabidiol on human experimental anxiety. J Psychopharmacol, 7, n. 1 Suppl, p. 82-88, Jan 1993. 